Georgia State University

ScholarWorks @ Georgia State University

Spring 5-1-2016

\title{
Designing and Orchestrating Embedded Innovation Networks: An Inquiry into Microfranchising in Bangladesh
}

Late M. Lawson-Lartego

Georgia State University

Follow this and additional works at: https://scholarworks.gsu.edu/bus_admin_diss

\section{Recommended Citation}

Lawson-Lartego, Late M., "Designing and Orchestrating Embedded Innovation Networks: An Inquiry into Microfranchising in Bangladesh." Dissertation, Georgia State University, 2016.

doi: https://doi.org/10.57709/8614033

This Dissertation is brought to you for free and open access by the Programs in Business Administration at ScholarWorks @ Georgia State University. It has been accepted for inclusion in Business Administration Dissertations by an authorized administrator of ScholarWorks @ Georgia State University. For more information, please contact scholarworks@gsu.edu. 


\section{PERMISSION TO BORROW}

In presenting this dissertation as a partial fulfillment of the requirements for an advanced degree from Georgia State University, I agree that the Library of the University shall make it available for inspection and circulation in accordance with its regulations governing materials of this type. I agree that permission to quote from, copy from, or publish this dissertation may be granted by the author or, in his absence, the professor under whose direction it was written or, in his absence, by the Dean of the Robinson College of Business. Such quoting, copying, or publishing must be solely for scholarly purposes and must not involve potential financial gain. It is understood that any copying from or publication of this dissertation that involves potential gain will not be allowed without written permission of the author.

Laté M. Lawson-Lartego, 


\section{NOTICE TO BORROWERS}

All dissertations deposited in the Georgia State University Library must be used only in accordance with the stipulations prescribed by the author in the preceding statement.

The author of this dissertation is:

Laté M. Lawson-Lartego,

1465 Great Oaks Drive

Lawrenceville, GA 30045, USA

The director of this dissertation is:

Dr. Lars Mathiassen

J. Mack Robinson College of Business

Georgia State University

35 Broad Street, Suite 1306

Atlanta, GA 30303 
Designing and Orchestrating Embedded Innovation Networks: An Inquiry into

Microfranchising in Bangladesh

By

Laté M. Lawson-Lartego

A Dissertation Submitted in Partial Fulfillment of the Requirements for the Degree

of

Executive Doctorate in Business

In the Robinson College of Business

Of

Georgia State University

GEORGIA STATE UNIVERSITY

J. MACK ROBINSON COLLEGE OF BUSINESS

2016 
Copyright by

Laté M. Lawson-Lartego

2016 


\section{ACCEPTANCE}

This dissertation was prepared under the direction of Laté M. Lawson-Lartego's Dissertation Committee. It has been approved and accepted by all members of that committee, and is has been accepted in partial fulfillment of the requirements for the degree of Executive Doctorate in Business Administration in the J. Mack Robinson College of Business of Georgia State University.

Richard Phillips, Dean

\section{DISSERTATION COMMITTEE}

Dr. Lars Mathiassen (Chair)

Dr. Karen Loch

Dr. Geoffrey Kistruck 


\section{ACKNOWLEDGEMENTS}

I thought of pursuing my doctoral degree in 1999 when I completed my second Master's Degree in the UK. I only had few years of professional experience at that time, and I decided to focus on my career in order to make a difference in the world. I have been very fortunate since then, working with renowned organizations such as PlaNet Finance for a very short time and CARE International for the most part of my professional life to date. I have enjoyed a successful career, moving from a country program manager position to a global level executive position. The itch to go back to school did not disappear. It was rather accentuated by my thirst to learn and to continue to grow, to amplify my impact to make a positive difference in people's lives in developing countries, and to foster a world of social justice and environmental sustainability. Our industry is also changing very rapidly with a stronger need for evidence-based management and program development and implementation. For me personally, understanding research and applying it to improve and scale up my work is paramount. Continuing to grow as a global leader was another objective that I sought to achieve.

After searching for the best and most appropriate program that can accommodate my busy lifestyle, I was fortunate to be accepted in the Executive Doctoral in Business Administration Program at Georgia State University. The program was a great fit for me, and I am eternally grateful for the opportunity to enroll and learn alongside my wonderful classmates and friends. The three year journey at Georgia State would not have been pleasant without their laughter, camaraderie, knowledge sharing, collaboration and support. Furthermore, the faculty and staff made our program a special one. I am so grateful to all of them, especially Maury, Tracy, Jorge, Elizabeth and Heather. I am particularly 
indebted to my dissertation and group research advisor and mentor Dr. Lars Mathiassen. Dr. Mathiassen is an extraordinary professor and human being, and I am so fortunate to be his student. I learnt a lot from him and have grown a great deal. Dr. Karen Loch and Dr. Geoffrey Kistruck, both members of my committee, were also wonderful to work with. Their critical advice and input made my dissertation and learning journey very enjoyable and rewarding.

The three year journey would not have been possible without the acceptance and support from my amazing wife and friend, Regina. She encouraged me to apply for the program and to dedicate the time to pursue it and to make the best out of it. She trusted me and demonstrated that throughout. She sacrificed a lot for me and our children. Regina, I love you beyond words!

My wonderful children, Rudy, Regis and Ryan, were also very understanding. I missed many important events in their lives, such as birthdays, orchestra performances, soccer games, and movie nights, among others. I hope you forgive me. I promise to make it up for you. I also hope my pursuit of this degree will inspire you in some way. I am confident you will do great! My mom, Regine and mother-in-law, Antoinette, were also wonderful, supporting me during this journey. I am very grateful for your love and kindness. I am also lucky to have the best siblings, Isaac, Veve, Ez, Wright and Laure, and their families in my life. I love you, and I am so grateful to count on you!

I am also very fortunate to have a support group of in-laws, extended family and friends throughout this journey. Thank you all! 
To my dear father, Charles, who passed a year into the program, I dedicate this dissertation to you. To my beloved uncle, Alfred, my grannies, Laure and Abou, my grandfathers, Eloi and Theodore, I also dedicate this dissertation to you! Rest in peace.

I am particularly grateful to my friends and colleagues at CARE Bangladesh for the tremendous help with my data collection. I single out Maruf Azam and Kanij Fatema for their dedication and support. I could not have done it without you. Thanks! Finally, my sincere appreciations go to Dr. Helene Gayle, ex CEO of CARE USA, who demonstrated her support to me when I shared my desire to pursue my doctoral degree with her. To all my bosses, teams, colleagues and friends at CARE, Leadership Atlanta and beyond, such as Faheem Khan, Thomas Reynolds, Farouk Jiwa, Dr. Bethann Cottrell, Dr. Maureen Miruka, Scott Merrill, Jamie Terzi, Christian Pennotti, Lauren Hendricks, Christine Svarer, Patrick Salomon, Dr. Kevin Mckague, Dr. Ted London, Dr. Larry Drake, etc. I thank you for your support, kindness, and contributions to my accomplishment.

Above and beyond all, I am grateful to my God. I praise him for his abundant grace and comfort.

I am proud to get this far in my lifelong learning journey. I am excited and very hopeful for this new chapter of my life. I dedicate it to contributing through my leadership, my profession and my research to continue to make a strong difference in poor people's lives, especially women and the youth, to make the world a better, just, and sustainable place for us, our children and the generations to come. So help me God! 


\section{TABLE OF CONTENTS}

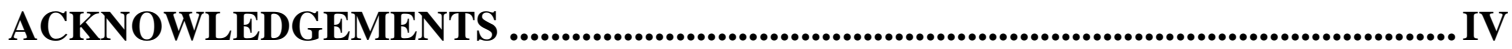

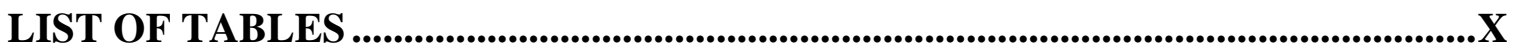

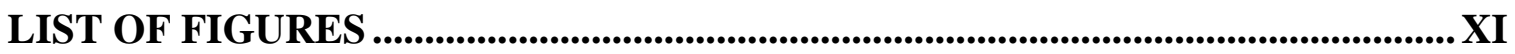

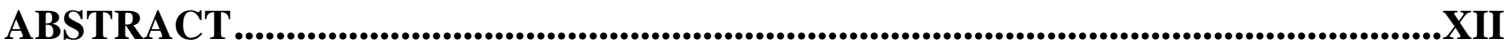

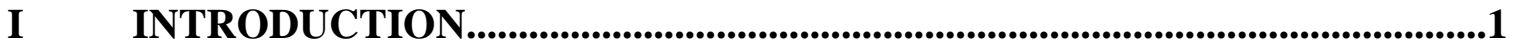

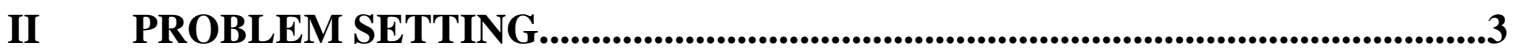

III THEORETICAL BACKGROUND ...........................................................7

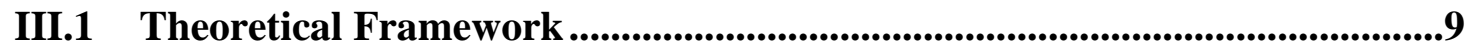

III.1.1 Network design ............................................................................... 10

III.1.2 Network orchestration: ....................................................................... 11

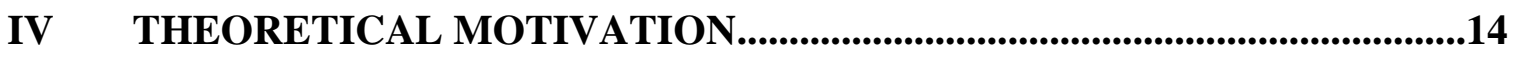

V METHODOLOGY: LONGITUDINAL CASE STUDY DESIGN .................17

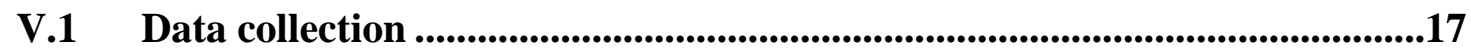

V.2 Data analysis ....................................................................................................21

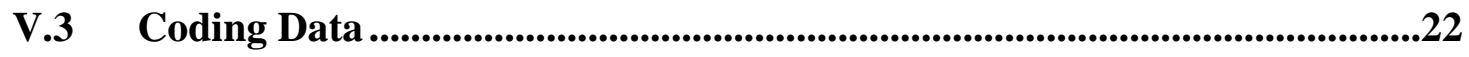

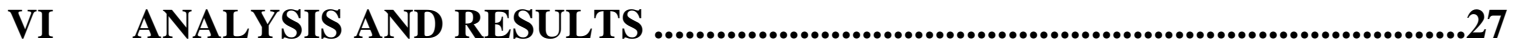

VI.1 2010-2012: Ideation and Creation ....................................................27

VI.1.1 Challenges faced by BOP farmers: ................................................. 27

VI.1.2 CARE's early trial and errors ......................................................... 28

VI.1.3 Early stage assessment and results:................................................29

VI.1.4 Ideating and creating the early stage business model: ............................ 31

VI.2 2012-2013: Development and Launch ....................................................34 
VI.2.1 Recruiting the first fifteen franchisees:............................................ 35

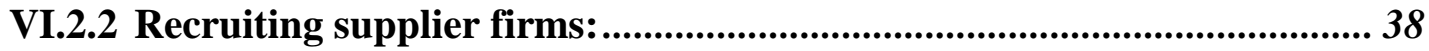

VI.2.3 Getting the first fifteen shops ready for conversion: ........................... 42

VI.2.4 Creating demand for quality: .........................................................43

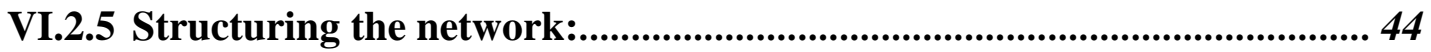

VI.2.6 Getting the supply chain right: .............................................................45

VI.2.7 Early stage challenges: ..................................................................46

VI.2.8 Managing early stage imprinting: .....................................................47

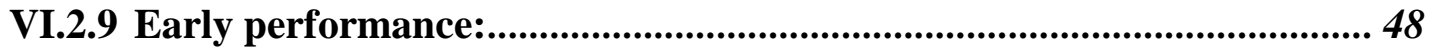

VI.3 2013-2014: Growth and Reconfiguration.........................................................50

VI.3.1 Formalizing the management of Krishi Utsho:................................... 51

VI.3.2 Recruiting additional members to the network: ....................................52

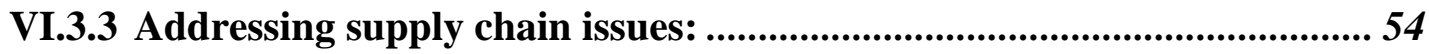

VI.3.4 Managing innovation appropriability: ...........................................55

VI.3.5 Managing knowledge mobility: .......................................................5

VI.3.6 Managing the long term sustainability of the network: ........................ 59

VI.3.7 Managing the stability of the network:..........................................60

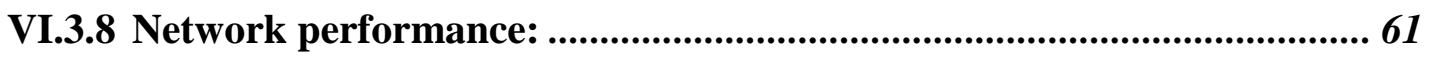

VI.4 2015 and onward: Consolidation and Expansion.....................................63 
VI.4.1 Developing a new business plan for the network:.................................. 64

VI.4.2 Understanding the impact on BOP farmers:.....................................66

VI.4.3 Recruiting new members to the network: ........................................6 68

VI.4.4 Introducing new line of products: ................................................69

VI.4.5 Continuous improvement of the supply chain: ...................................69

VI.4.6 Organizing the first closing event:..................................................... 71

VI.4.7 Securing additional funding for the network:.................................... 71

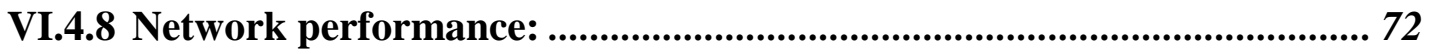

VI.4.9 Managing the network stability and sustainability: ............................. 74

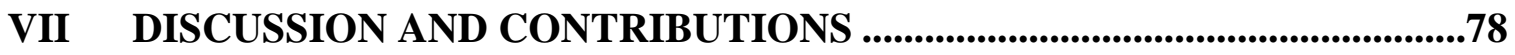

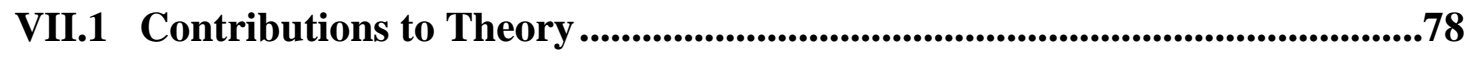

VII.2 Contributions to practice.........................................................................91

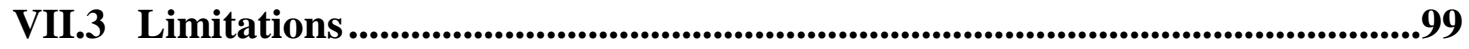

VII.4 Conclusion........................................................................................................100

VIII APPENDIXES ......................................................................................103

Appendix A: Name of supplier firms in Krishi Utsho network ...........................103

Appendix B: Detailed results of test on Coconut Oil Cake ...................................103

Appendix C: Customer impact results...................................................... 104

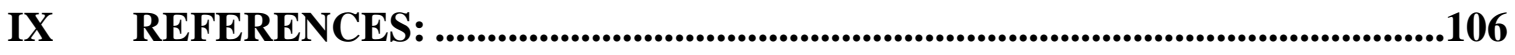

X VITA 


\section{LIST OF TABLES}

Table 1: Summary style composition of the proposed research ....................................

Table 2: key constructs in orchestration of innovation network ...................................16

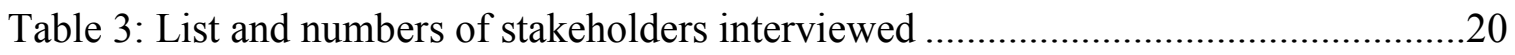

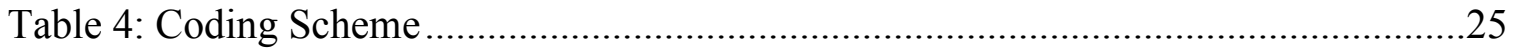

Table 5: Challenges and opportunities identified during the assessment .........................31

Table 6: Innovation Networking during the Ideation and Creation Stage ........................34

Table 7: Innovation Networking during the Development and Launch Stage .................50

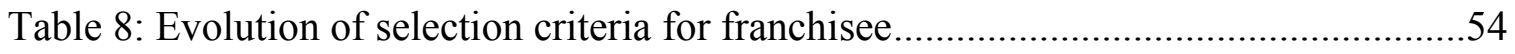

Table 9: Innovation Networking during the Growth and Reconfiguration Stage.............63

Table 10: Availability of inputs before and after Krishi Utsho ....................................67

Table 11: Innovation Networking during the Consolidation and Expansion Stage...........77

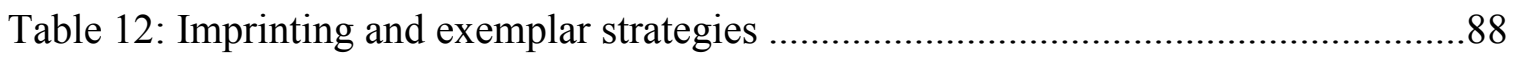




\section{LIST OF FIGURES}

Figure 1: Krishi Utsho's Business model ................................................................6

Figure 2: Network orchestration framework (Dhanaraj and Parkhe, 2006) .....................12

Figure 3: Visualization of the process that will be central to data collection ...................19

Figure 4: Approach to Data Analysis (adopted from Singh, 2011) ...............................22

Figure 5: Krishi Utsho logo, photo credit of Krishi Utsho .......................................... 34

Figure 6: Before conversion into Krishi Utsho, photo credit from author........................37

Figure 7: After conversion into Krishi Utsho, photo credit from author ..........................38

Figure 8: Franchisee's selection and conversion process modified by author.................41

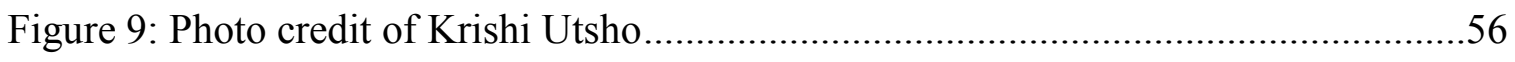

Figure 10: Household Income before and after Krishi Utsho.....................................67

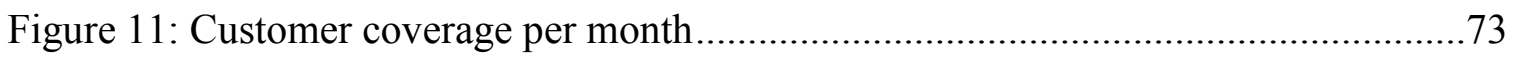

Figure 12: Franchisor Sales and Income in 2015 .................................................. 74

Figure 13: Adapted framework for network design and orchestration ..........................91 


\begin{abstract}
Designing and Orchestrating Embedded Innovation Networks: An Inquiry into Microfranchising in Bangladesh

By

Laté M. Lawson-Lartego

May 2016
\end{abstract}

Committee Chair: Lars Mathiassen

Major Academic Unit: J. Mack Robinson College of Business

Microfranchising has emerged as a potential strategy to rapidly scale up entrepreneurship within base of the pyramid (BOP) markets in order to contribute to poverty reduction and to increase economic growth. However, we know little about how such networks are designed and orchestrated in resource-scarce settings to co-create value with the different parties involved. To address this gap, we report a longitudinal case study of an emerging microfranchise network social enterprise, currently facilitated by CARE, a global humanitarian and development organization, to provide timely access to quality, affordable agricultural input and services for millions of small-scale poor farmers in Bangladesh. We draw on the orchestration of innovation network theory developed by Dhanaraj and Parkhe (2006) and the notion of network imprinting (Marquis and Tilcsik, 2013) to analyze the emerging microfranchise network in Bangladesh. As a result, we offer two types of contributions to theory and to practice. First, we offer a detailed account of how these theories are relevant and applicable to analyze and explain the emergence of microfranchise networks, and we present two key propositions to generalize to theory. Furthermore, we propose an integrated framework, combining the two theories for scholars and practitioners interested in designing innovation networks. Second, based on these empirical results and extant theory, we offer three main lessons for practitioners to advance 
the industry by designing and orchestrating microfranchise innovation networks in embedded contexts to achieve positive financial and social impacts.

Key words: Social enterprise, microfranchising, orchestration of innovation network, network imprinting, bottom of the pyramid, farmers, agriculture input and services. 


\section{INTRODUCTION}

With about half of the world population at the Base of the Pyramid (BOP) — which is estimated to be over 2.6 billion people living with less than $\$ 2$ a day (World Bank, 2014) and the decreasing aid investment, poverty reduction could no longer be treated only as a charity case. The seminal work done by Prahalad and Hammond in 2002 has attracted enormous attention from Multi-National Companies to the BOP as an opportunity to grow new markets and contribute to poverty reduction. Charitable organizations are also evolving their strategy to sustainably reduce poverty and multiply impact with marketbased solutions (Fowler, 2000). New business models have emerged in the BOP market, one such model is microfranchising. The term microfranchising differs from the traditional notion of franchising by its emphasis on generating public benefits that has the potential to reduce poverty and create social benefits for BOP rather than generating private wealth (Christensen, Parsons, \& Fairbourne, 2010). Nevertheless, to survive and generate the necessary financial resources for scaling, microfranchises retain a focus on economic growth and efficiency as a means of achieving their poverty alleviation goals (Kistruck, Webb, Sutter, \& Ireland, 2011).

Although there is an increasing interest in microfranchising and early stage research has brought attention to many of the potential benefits of microfranchising (Fairbourne, 2007; Gibson, 2007; Magleby, 2007), there is a gap in the literature analyzing how this model could be orchestrated as an innovation network to co-create value with BOP entrepreneurs and contribute to poverty reduction. Furthermore, emerging microfranchise networks assemble existing entrepreneurs with their past and current ties, practices and position into a brand new business model. Effective leveraging of the microfranchising 
model therefore requires an awareness of the imprinting that those entrepreneurs and firms come with to join the new business and strategies and tactics to manage and leverage the imprinting in order to achieve the new outcomes. Against this backdrop, we set out to understand how the orchestration of innovation network theory combined with the network imprinting concept can be used to study an emerging microfranchise network in the food and agriculture sector. Our study takes a step forward exploring how these theories could be extended, combined and adapted for scholars and practitioners interested in designing and orchestrating microfranchise innovation networks in resources scarce areas for poverty reduction and value co-creation. Overall then, the dissertation makes use of the style composition (Mathiassen et al., 2012) summarized in Table 1 below. The different elements of this research design will be motivated, described and further elaborated in the subsequent sections of this dissertation.

\section{Table 1: Summary style composition of the proposed research}

\begin{tabular}{|l|l|}
\hline $\begin{array}{l}\text { RQ: } \\
\text { Question }\end{array}$ & $\begin{array}{l}\text { How does an organization, in this case CARE, design and orchestrate an } \\
\text { embedded microfranchise innovation network to facilitate the timely provision of } \\
\text { affordable and quality agriculture inputs and services to BOP farmers in } \\
\text { Bangladesh? }\end{array}$ \\
\hline $\begin{array}{l}\text { P: Problem in the } \\
\text { real world }\end{array}$ & $\begin{array}{l}\text { With over 800 million people in the world going hungry every day, and with a } \\
\text { broken agriculture value chain unable to deliver quality and affordable input and } \\
\text { services to BOP farmers, how to develop and sustain a network of } \\
\text { microfranchisees and other institutions to offer uninterrupted, timely access to } \\
\text { quality, affordable agricultural input and services to BOP farmers in Bangladesh? }\end{array}$ \\
\hline AC: Area of concern & BOP and microfranchise literature \\
\hline F: Theoretical & $\begin{array}{l}\text { Orchestration of innovation networks } \\
\text { Network imprinting }\end{array}$ \\
\hline M: Methodology & $\begin{array}{l}\text { Longitudinal qualitative case study } \\
\text { C: Contribution }\end{array}$ \\
$\begin{array}{l}\text { Cp: Three lessons offered to improve the design and orchestration of } \\
\text { microfranchise innovation networks to achieve expected outcomes and long term } \\
\text { sustainability. } \\
\text { Ca: A detailed account of the design and orchestration of a microfranchise network } \\
\text { through the lens of orchestration of an innovation network theory and network } \\
\text { imprinting theory with three propositions to generalize to theory } \\
\text { Cfa: An integrated framework for designing and orchestrating microfranchise } \\
\text { networks for BOP engagement based on extant theory and drawing from empirical } \\
\text { evidence }\end{array}$ \\
\hline
\end{tabular}




\section{PROBLEM SETTING}

We chose the food and agriculture sector because of the pressing need to increase agriculture productivity in many developing countries around the globe, with a marketbased approach to provide over 800 million hungry people access to nutritious food (FAO, 2012), and to enable them to rise out of poverty. Bangladesh, in particular, is a country with a very high level of poverty, despite recent economic growth. Over $38 \%$ of the 160 million people are food insecure and live in extreme poverty. Agriculture continues to play a strong role in the economy, despite a downward trend, representing $15.89 \%$ of the country's GDP in 2014 (World Bank, 2014). Roughly 80\% of Bangladesh's population lives in remote rural areas, and $80 \%$ of these rural households make their living either as small-scale farmers or as landless cattle owners. Both groups play a prominent role in the nation's dairy sector, producing more than $90 \%$ of the country's milk. However, the formal dairy sector in Bangladesh has failed to integrate or benefit BOP farmers and landless dairy producers, giving them little incentive to increase production. Those producers also have poor access to the agricultural input and services they need (feed, fodder, medicine, vaccination, artificial insemination and other related input) because the input and service providers often do not serve the rural dwellers, or those who serve them are not in any sort of organized network and have a fragmented supply chain. As a result, outputs from the cattle from small-scale dairy farmers fall short of meeting the country's needs. In Bangladesh, 10 million dairy cattle, including 4 million cross-breeds, produce 2.82 million tons of milk. This is much lower than in the neighboring Pakistan, where only 5.5 million dairy cattle produce 25 million tons of milk (Hemme, 2010). This represents one liter of milk per cattle in Bangladesh compared to 25 liters per cattle in Pakistan. Milk demand, 
measured by per capita consumption, is increasing by $4 \%$ per year, which is higher than the growth in milk production $(3.6 \%)$. This has led to a continuous widening of the gap between milk supply and demand (Uddin et al. 2011). This same situation applies to other agriculture sectors, such as crop, fishery and agroforestry, in Bangladesh and around the developing world where BOP farmers are poverty-trapped due to a lack of timely access to affordable, quality agricultural inputs and services.

In an effort to address these constraints, CARE initiated a pilot initiative in Bangladesh in 2012 with the aim of creating a sustainable social enterprise called Krishi Utsho. The objective for Krishi Utsho is to provide timely access to the affordable, quality agricultural input and services needed by BOP farmers to increase their dairy outputs and to integrate them into the dairy value chain, but doing so in a financially sustainable manner. In order to achieve these dual objectives, Krishi Utsho is employing a franchising model known in the literature as Microfranchise (Fairbourne, 2007).

Using this microfranchising model, Krishi Utsho is seeking to integrate existing, although malfunctioning, individual micro-entrepreneurs' agro-input shop owners into a wellfunctioning, credible, cohesive and well-branded network. In this process, Krishi Utsho is creating multiple partnerships with private sector input supplier firms (such as feed manufacturers and pharmaceutical companies) and other types of firms in order to improve the function of the input supply chain. Krishi Utsho monitors the performance of the shop owners within the microfranchise network, assisting them with solutions to management problems, and providing them with tailored business management training and various cattle health services. Figure 1 depicts the emerging Krishi Utsho microfranchise network. So far, Krishi Utsho has integrated 110 microfranchisees of various sizes into the network 
with total sales of approximately $\$ 1$ million per year. Under this initiative, farmers have seen milk production increase at least $50 \%$, as well as an increase in family milk consumption and income. Krishi Utsho branded franchisee shops have also grown at a rapid rate and shop owners' sales and net incomes have increased by at least $50 \%$ over the past three years. The challenge for Krishi Utsho is to sustainably design and orchestrate this network and to continue to innovate in order to allow millions of BOP farmers' uninterrupted quality, and the affordable access to the agricultural inputs and services they need. In doing so, Krishi Utsho needs to address the imprinting challenge of the path dependencies of the network. 


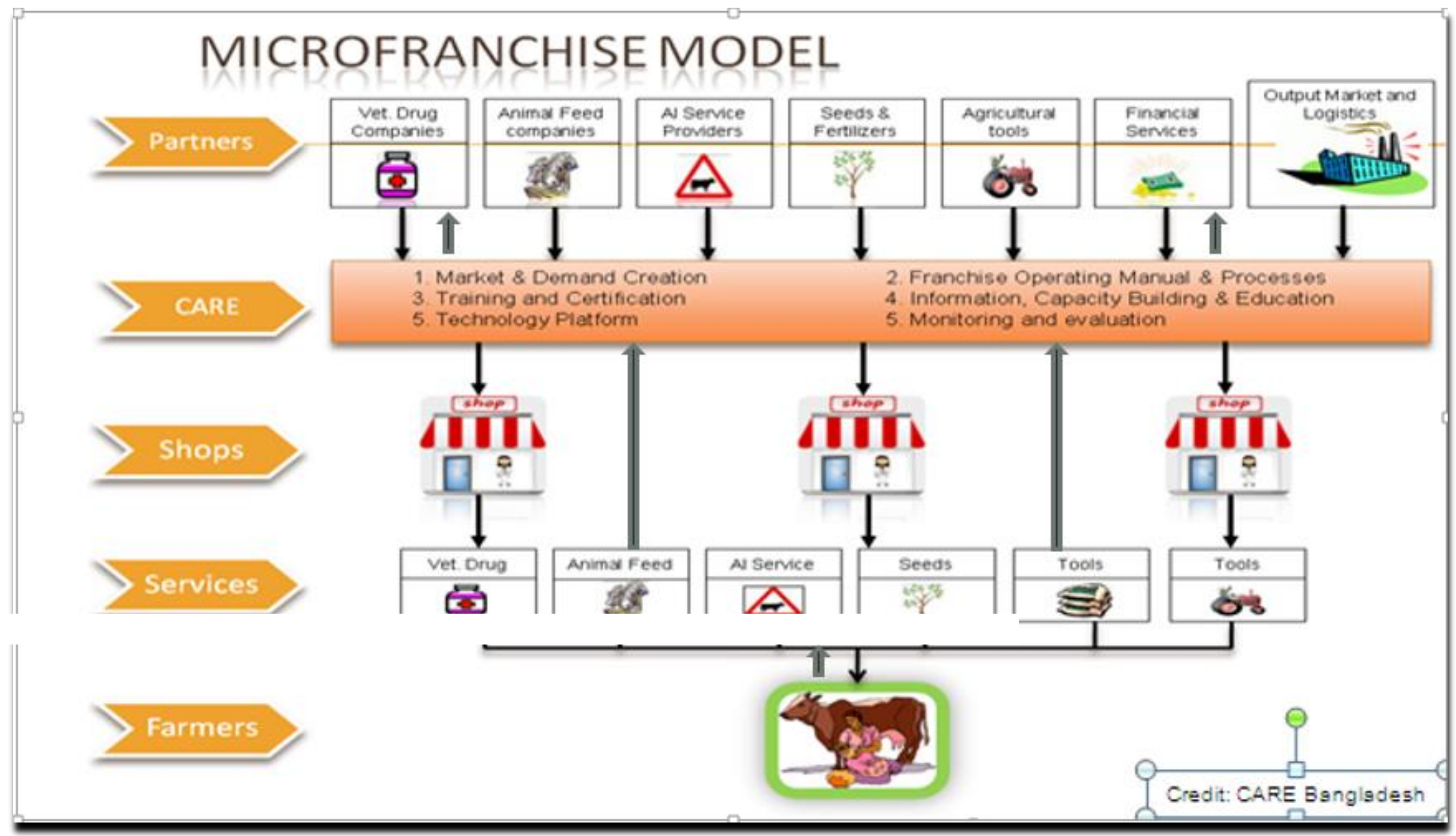

Figure 1: Krishi Utsho's Business model 


\section{THEORETICAL BACKGROUND}

As much as businesses have to continuously innovate to remain competitive in their market (Van de Ven 1986), global and national nonprofit organizations aiming to combat poverty and competing for limited donor resources are also re-inventing themselves to stay innovative and relevant. To innovate, nonprofit organizations have to forge new types of partnerships with commercial as well as non-commercial actors. Increasingly, many nonprofit organizations have also embraced the concept of social enterprise which consists of utilizing market based approaches and solutions to solve complex poverty issues, reduce social harms and advance public benefits (Rangan et al., 2008).

One such type of social enterprise is the microfranchise network. Microfranchise has emerged as an innovative business model with high potential to scale up entrepreneurship at the BOP to co-create value with those entrepreneurs and contribute to public goods and poverty eradication (Fairbourne, 2007). Microfranchising is a variant of the traditional franchising approach, which is a contractual arrangement in which one firm, the franchisor, licenses a business concept, operational system, or trademark to a second firm, the franchisee. For the franchisor, franchising is typically a growth strategy utilized to expand across geographic markets while overcoming agency concerns and capital constraints associated with internal growth (Combs \& Ketchen, 1999a, 1999b). For the franchisee, franchising offers the benefits of operating one's own business with the mitigation of risks, facilitated by being able to leverage the franchisor's proven brand and standardized business format (Kaufmann \& Dant, 1996; Kistruck et al., 2011).

While Microfranchising has many commonalities with the traditional franchising model, the intrinsic orientation to create social good and the wellbeing of the franchisees 
in the BOP market is one key difference between both models. The term "micro" also connotes a number of distinctions with the traditional franchise model. One such difference is the fact that the emerging model is being adapted to BOP market and tends to be at smaller scale (Fairbourne, 2007). For instance, initial investments by microfranchisees typically do not exceed more than $\$ 1,500$ (Lehr, 2008). Furthermore, microfranchisors often convert existing micro-entrepreneurs with their past ties and practices into a new network. The emergent business continues to evolve, improved, standardized, packaged and ready to be scaled up for rapid adoption by interested BOP entrepreneurs. This is the approach taken by CARE in Bangladesh in the agriculture and food sector to enable millions of BOP farmers to access affordable and quality agriculture input and services in a sustainable and timely manner. In doing so, CARE has to forge and orchestrate a number of partnerships upstream as well as downstream to co-create value.

Existing research on microfranchising focuses almost exclusively on the potential social benefits to the local communities, and even more so to the microfranchisee- the opportunities for job creation (Christensen et al.), the reduced risk from buying into a "proven business system" (Fairbourne), and the benefits of belonging to part of a “democratic network" (Magleby, 2007, p. 46). There is no existing research on how an intermediary entity such as CARE can design and orchestrate such networks of actors through the concept of microfranchise to innovate at the BOP market and to co-create value with various stakeholders involved. Furthermore, there is no empirical research on strategies and tactics used to manage and leverage the past and current tie of those entrepreneurs to achieve the outcome of the new network. 
Against this backdrop, our goal is to understand how does an organization, in this case CARE, design and orchestrate an embedded microfranchise innovation network to facilitate the timely provision of affordable and quality agriculture inputs and services to BOP farmers in Bangladesh. Specifically, we draw on the concept of orchestration of innovation network developed by Dhanaraj and Parkhe (2006) and combine it with the concept of network imprinting (Marquis and Tilcsik, 2013) to understand such phenomena. To gain empirical evidence, we conducted a longitudinal case study on the microfranchise network in Bangladesh.

\section{III.1 Theoretical Framework}

The orchestration of the innovation network framework developed by (Dhanaraj \& Parkhe, 2006) focuses on how a hub as coordinator can improve outcomes by facilitating interactions between the firms and institutions involved in a network. The idea here is that firms are part of a network to create or benefit from innovation, and there is a strong role needed from a central firm to manage the network and ensure that knowledge gets created and distributed in the network and its members benefit. This central firm, called the hub, is defined as one that possesses prominence (Wasserman \& Galaskiewicz, 1994) and power (Brass \& Burkhardt, 1993) gained through individual attributes and a central position in the network structure, and that uses its prominence and power to perform a leadership role in pulling together dispersed resources and the capabilities of network members (Dhanaraj \& Parkhe, 2006).

The network of focus for this framework is viewed as loosely coupled. This means that participant firms in the network retain some autonomy and their identity while remaining responsive and in some cases accountable to the network (Weick, 1976). Being 
able to orchestrate such a network to achieve the expected outcome is therefore critical. Dhanaraj and Parkhe define network orchestration as a set of deliberate purposeful actions undertaken by the hub firm as it seeks to create value, (expand the pie) and extract value (gain a larger slice of the pie) from the network (Dhanaraj \& Parkhe, 2006). In the particular context of innovation networks, "where knowledge is the chief currency and is dispersed," the first task of orchestration for the hub firm is to ensure that knowledge is mobile within the network. This is called knowledge mobility. Two other key processes are part of the orchestration of innovation network function: managing innovation appropriability and network stability. In addition to these functions, the hub firm has to ensure that the network is properly designed. Figure 2 helps visualize the network orchestration framework that is the theoretical backbone of our research (Dhanaraj and Parkhe, 2006). We discussed in depth in the next section a few important concepts relevant for our research.

\section{III.1.1 Network design}

Three important design issues are related to network design: membership, structure, and position (Dhanaraj \& Parkhe, 2006).

Network membership defines who can join or cannot join the network. It is a minimum agreement defined by the network members under the leadership of the hub firm. The size and diversity of the network and the value and knowledge potential to its members are all critical elements (Levén, Holmström \& Mathiassen, 2014).

Network structure is comprised of network density and autonomy. Network density, refers to the degree of formal and informal relations amongst members that keep the network together. A hub can change network density by developing existing relations, by establishing new promising relations, and by recruiting new organizations that already have 
relations with existing members. A hub can impact network autonomy through the way it recruits members and by designing structures that enable collaboration (Levén et al., 2014).

Finally, network position refers to the centrality, confidence and status ascribed to the hub by the network members. These qualities are primarily reflected in the network members' perception of the hub's performance as both network designer and orchestrator. Hence, the hub can impact its position by effectively communicating the virtues of the network and the value-adding role the hub is playing as designer and orchestrator of the network (Levén et al., 2014).

\section{III.1.2 Network orchestration:}

Network orchestration has to deal with three main processes: managing knowledge mobility, managing innovation appropriability, and managing network stability.

Knowledge mobility is defined as the ease with which knowledge is shared, acquired and deployed within the network. (Dhanaraj \& Parkhe, 2006). The hub firm has a central role to play in ensuring that any knowledge created is assessed for its relevance and is transferred in a timely fashion to different parts of the network where it is relevant. Managing innovation appropriability ensures that value is distributed equitably and perceived as such by network members. The hub can ensure innovation appropriability and an equitable distribution of value through trust, procedural justice, and joint asset ownership. While formal contracts are important, the strength of an appropriability regime rests more on social interaction between member firms. Principles of procedural justice like "bilateral communications, ability to refute decisions, full account of the final decisions and consistency in the decision-making process" (Dhanaraj and Parkhe, 2006, p. 663) are examples of how the hub can support knowledge mobility by strengthening 
innovation appropriability (Levén et al., 2014). Finally, ensuring network stability, even when the network is loosely coupled remains very important and strategic to avoid network disintegration. The hub firm can increase network stability by first enhancing the network reputation. This can be done through a common identity or strong branding. Second, the hub can fortify reciprocal behavior by being an effective promoter of collaboration in which network members can anticipate a future benefit by collaborating together in the present situation (Parkhe, 1993). Third, a hub can build robust relations by building multiplexity, by fostering multiple collaborations between members themselves and between members and hub firms (Dhanaraj \& Parkhe, 2006).

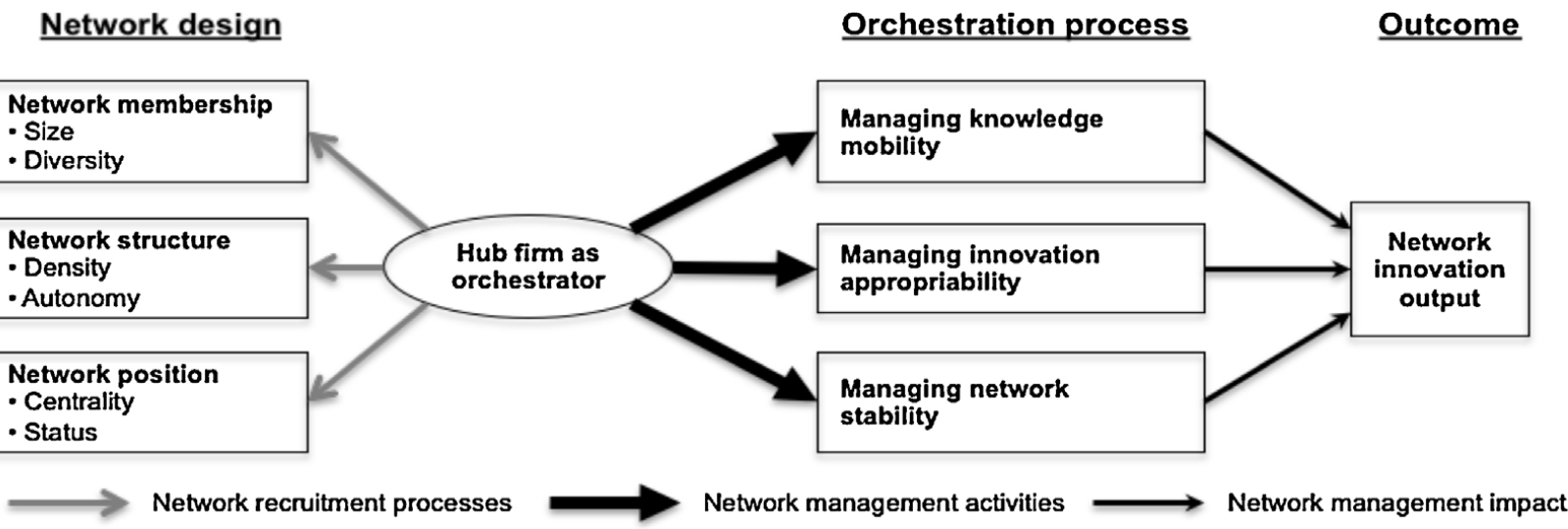

Figure 2: Network orchestration framework (Dhanaraj and Parkhe, 2006)

Current and future network members, including shops owners, supplier firms and other institutions who will integrate into the microfranchise network each come with their own imprint. This means each member of the network has pre-established social and business related ties and practices prior to joining the microfranchise network. In order to effectively design and orchestrate the microfranchise innovation network, CARE as the hub firm, should not ignore this imprinting phenomenon and should develop strategies and tactics to manage and leverage it. 
The concept of imprinting emerged more than a century ago in studies of animal behavior (Marquis and Tilcsik, 2013). Stinchcombe pioneered the concept in organizational studies in his classic essay of 1965 on "Social Structure and Organizations", although he did not use the term directly according to many authors including Lounsbury and Ventresca, 2002. Marquis and Tilcsik defined the term imprinting as a process whereby, during a brief period of susceptibility, a focal entity develops characteristics that reflect prominent features of the environment, and these characteristics continue to persist despite significant environmental changes in subsequent periods. Three essential concepts emerge from this definition:

- The existence of a temporally restricted sensitive period characterized by high susceptibility of environmental influence;

- The powerful impact of the environment during the sensitive period such that the focal entity comes to reflect elements of the environment at that time; and

- The persistence of the characteristics developed during the sensitive period even in the face of subsequent environmental changes.

Weaving the network imprinting into the orchestration of innovation network theory would give us an opportunity to understand how the past ties of the current and future members of the network would play out to achieve the goal of this new business model. As noted by Marquis and Tilcsik (2013), this analysis will allow us to understand the lingering influence of past network structures and positions. They suggested two areas of attention that we will also consider in addition to the key concepts presented in Dhanaraj and Parkhe's framework. 
1- The importance of past ties among network members and structural positions on the current microfranchise network

2- The network persistence, whereby the structure of a network bears imprint of conditions that prevailed during relevant sensitive period, such that network interactions are reproduced over time and across a number of actors (Ahuja et al. 2012).

Taking into account these two essential elements in our research would help us to understand how past ties, structural positions and network persistence could cast an influential shadow over the current and innovative approach CARE has introduced. This would also help to understand how the imprinting is managed and leveraged to enable hundreds of thousands of BOP farmers to timely access quality and affordable agriculture inputs and services in Bangladesh.

Table 2 summarizes key concepts in the orchestration of innovation network and network imprinting theory and the next sections present the research method, timelines, key contributions we expect to make and how our dissertation will be structured.

\section{THEORETICAL MOTIVATION}

Dhanaraj \& Parkhe (2006) developed a relevant framework for our research to analyze the microfranchise network that CARE is orchestrating in Bangladesh to provide timely access to affordable, quality input and services to BOP farmers. We think that theoretically it is important to test this framework within the microfranchise model to improve the understanding of how the network is built and orchestrated. However, we anticipate some modification of this framework due to several reasons that vary from a 
typical business where profit maximization is the main driver. Some of the differences we anticipate are specific to our research setting include:

- First, our research setting, in this case, the BOP context, is characterized by limited financial resources, weak human capacity, poor infrastructures and a weak legal framework.

- Second, the outcomes pursued by CARE as a social enterprise go beyond innovation output. Given the innovative nature of microfranchising as a new business model in the BOP space to standardize business practices and to reach scale and efficiency, CARE's goal is also to co-create values between the microfranchisees and the population they serve.

- Third, a characteristic of the microfranchise network is that the hub firm, in this case CARE, is not in profit maximization mode, although achieving financial sustainability is important. Therefore, CARE might orchestrate the innovation network in a different way from a pure business perspective.

- Finally, we anticipate the network imprinting to play a role that could influence how the network is designed and orchestrated. The network imprinting was not part of the orchestration of the innovation network theory proposed by Dhanaraj and Parkhe, 2006.

Given all the reasons provided above, our empirical study will help to contribute to answering the question: how does the network design and orchestration process differ from the one proposed by Dhanaraj and Parkhe, and what modification could therefore be proposed? 
Table 2: key constructs in orchestration of innovation network

\begin{tabular}{|c|c|c|}
\hline Themes & Concepts & Sub concepts \\
\hline \multirow{3}{*}{$\begin{array}{l}\text { Network } \\
\text { Design }\end{array}$} & Network membership & $\begin{array}{ll}- & \text { Network size } \\
\text { - } & \text { Network diversity }\end{array}$ \\
\hline & Network structure & $\begin{array}{ll}- & \text { Network density } \\
\text { - } & \text { Network autonomy } \\
\text { - } & \text { Ties among members }\end{array}$ \\
\hline & Network position & $\begin{array}{l}\text { Status ascribed to the hub by the network members such } \\
\text { as: } \\
\text { - Centrality } \\
\text { - } \quad \text { Confidence }\end{array}$ \\
\hline \multirow[b]{3}{*}{$\begin{array}{l}\text { Network } \\
\text { Orchestration }\end{array}$} & $\begin{array}{l}\text { Managing knowledge } \\
\text { mobility }\end{array}$ & $\begin{array}{ll}- & \text { Knowledge management absorption } \\
- & \text { Network identification } \\
- & \text { Inter-organizational socialization }\end{array}$ \\
\hline & $\begin{array}{l}\text { Managing innovation } \\
\text { appropriability }\end{array}$ & $\begin{array}{ll}- & \text { Trust } \\
- & \text { Procedural justice } \\
- & \text { Joint asset ownership }\end{array}$ \\
\hline & $\begin{array}{l}\text { Managing network } \\
\text { stability }\end{array}$ & $\begin{array}{ll}\text { - } & \text { Enhancing reputation } \\
\text { - } & \text { Lengthening the shadow of the future } \\
\text { - } & \text { Building multiplexity }\end{array}$ \\
\hline \multirow[t]{2}{*}{$\begin{array}{l}\text { Network } \\
\text { Performance }\end{array}$} & Hub firm & $\begin{array}{l}\text { Lead firm orchestrating network of loosely coupled } \\
\text { members. }\end{array}$ \\
\hline & $\begin{array}{l}\text { Network innovation } \\
\text { output }\end{array}$ & $\begin{aligned} & \text { Could be: } \\
& \text { - } \text { Technological innovation, } \\
& \text { - } \text { Financial returns, } \\
& \text { - } \text { Process improvement, } \\
& \text { - } \text { and positive impact on targeted population }\end{aligned}$ \\
\hline \multirow[t]{3}{*}{$\begin{array}{l}\text { Network } \\
\text { Imprinting }\end{array}$} & Past ties & $\begin{array}{ll}- & \text { Weak past tie } \\
- & \text { Moderate past tie } \\
- & \text { Strong tie }\end{array}$ \\
\hline & Structural position & $\begin{array}{ll}- & \text { Dominant position } \\
- & \text { Lower position } \\
- & \text { Bridging position } \\
\end{array}$ \\
\hline & Network persistence & $\begin{array}{cl}\text { Level of change in: } \\
-\quad \text { Behavior } \\
-\quad \text { Practice }\end{array}$ \\
\hline
\end{tabular}




\section{METHODOLOGY: LONGITUDINAL CASE STUDY DESIGN}

Grounded in an interpretative research philosophy, we decided to adopt a longitudinal in-depth case study method, based on a number of considerations. First, multiple data sources and theory-driven data analysis are key characteristics of case study research (Yin, 2003), and we have access to very rich data about the design and orchestration of the microfranchise network that CARE is leading in Bangladesh. Second, the case study method has a distinct advantage in situations when how or why questions are being asked about events over which the investigator has little or no control (Yin, 2003). Our investigation was driven by a question based on retrospective and current analysis of events that had, and still are, shaping how the microfranchise network is being developed. Finally we took an engaged scholarship approach drawing from Van de Ven (2007), which promotes a participatory form of research for obtaining the views of the key stakeholders to understand a complex problem or case. Our end goal was to promote knowledge that is more penetrating and insightful for both practice and theory.

\section{V.1 Data collection}

Our data collection approach sought to capture information from various perspectives within and outside the microfranchise network in Bangladesh and through various modes to (a) avoid biases resulting from social desirability or from using a single perspectives (Kistruck et al. 2015) and (b) develop a comprehensive empirical account and a framework to explain why and how CARE designed and orchestrated a microfranchise network to co-create value. We collected data in Bangladesh and in North America from various sources. Our data collection attempted to understand the baseline situation to 
uncover pre-existing conditions in terms of past ties, practices and positions before CARE introduced the microfranchise network. At its core, data collection focused on the activities and conditions under which the network has been designed and orchestrated, and on the challenges and results that have emerged during the process. We also kept in mind the end state that CARE, the network designer, and the orchestrator sought to achieve. Our data collection covered January 2010 through December 2015. This gave us nearly six years of process data for our research. Figure 3 depicts the various stages of the development of the microfranchise network. Those four stages became evident during our data analysis. We also made use of any relevant document and archival data collected by CARE and the Krishi Utsho network in Bangladesh, such as the business plan, proposals submitted for funding, progress reports, the baseline study, the market research report, meeting notes, the contract agreement, trip reports, monitoring and evaluation reports and other relevant documents. We also collected field observations. We secured approval from the Institutional Review Board of Georgia State University in May 2015.

We collected data in two waves to obtain an in-depth perspective of the network and to be able to thoroughly analyze the data. This enabled us to respond to our research question and to gain insights to develop a framework to contribute to practice and theory. The first field data collection took place in June 2015 in Bangladesh. The first data collection was in the form of semi-structured interviews targeted to the key constructs we have outlined in this research proposal. After coding and the first data analysis, we narrowed down the key questions we wanted to research further and conducted the second wave of data collection, mostly with the leadership of the Krishi Utsho network in Bangladesh and other key informants able to provide insights to inform our research. This 
iterative approach helped us to refine our questions and to ensure that we had rich and targeted data for our research.

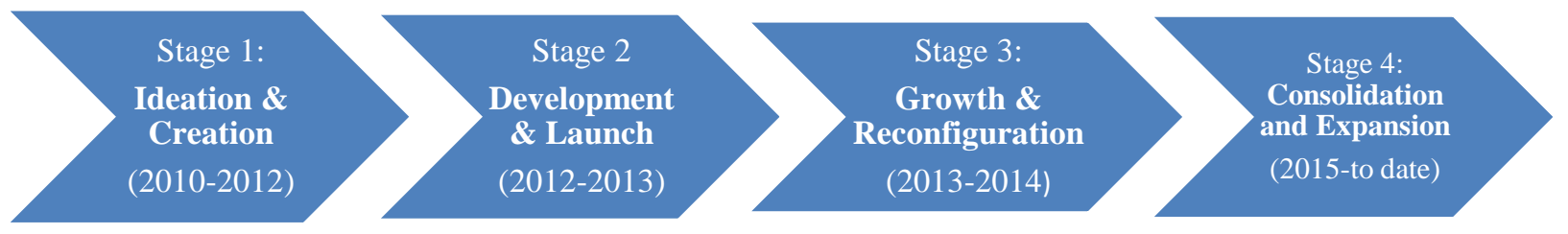

\section{Figure 3: Visualization of the process that will be central to data collection}

The study population is the key stakeholders of Krishi Utsho. We interviewed a total of 28 people. Three of them were interviewed again in the second wave. Seven of the people interviewed were Krishi Utsho employees, and two were ex-CARE staff who were involved at the very beginning of the network, at the Ideation and Creation Stage as well as the Development and Launch stage. We also interviewed one CARE Bangladesh employee. On the franchisees' side, we interviewed three franchisees from the Development and Launch Stage and four who joined the network in the Growth and Reconfiguration stage. On the supplier side, we interviewed all of the eight suppliers currently involved in the network. We interviewed high-level representatives, such as the CEO and the Regional Sales Directors for each supplier firm. A prominent financial institution in Bangladesh, that Krishi Utsho had attempted to finance the network with, was also interviewed. A representative of a competitor network of agro-dealer franchisees in Bangladesh was also interviewed. A shop owner with similar characteristics to the one that Krishi Utsho selected to join the network was also interviewed. Table 3 presents the list of various stakeholders we interviewed and the number of interviews we conducted with them. 
Table 3: List and numbers of stakeholders interviewed

\begin{tabular}{|l|l|l|l|}
\multicolumn{1}{|c}{ Category of interviews } & \multicolumn{1}{c|}{$\begin{array}{c}\text { \# of } \\
\text { interview: } \\
\text { Wave 1 }\end{array}$} & $\begin{array}{c}\text { \# of } \\
\text { Wave 2 }\end{array}$ & $\begin{array}{c}\text { \# of } \\
\text { hours }\end{array}$ \\
\hline CARE staff (current and ex) & 3 & 1 & $7 \mathrm{~h}$ \\
\hline Krishi Utsho staff & 7 & 2 & $13 \mathrm{~h}$ \\
\hline Franchisees & 7 & 0 & $7 \mathrm{~h}$ \\
\hline Suppliers & 8 & 0 & $8 \mathrm{~h}$ \\
\hline Competitions & 2 & 0 & $3 \mathrm{~h}$ \\
\hline Partner & 2 & 0 & $1 \mathrm{~h}$ \\
\hline Total \# of interviews & 1 & 3 & $39 \mathrm{~h}$ \\
\hline
\end{tabular}

All the first wave interviews were conducted in the field in Bangladesh. The second wave interviews were conducted through Skype, with interviewees in North America and Bangladesh. Each interview lasted about an hour, with a few exceptions. Given the qualitative nature of this case study, we are not concerned about generalization to a broader population.

The research team worked with the leadership of Krishi Utsho to select the research participants to be interviewed. The general manager of Krishi Utsho and his deputy were our main points of contact for the discussion and the selection of the research participants. Once the participants were selected and agreed upon between us, the researcher reached out to them via an official letter to notify them of their selection to participate in the study. We sent an official letter requesting the interviewees to participate in the study in no coercive manner. The letter clearly stated that participation was completely voluntary. The official letter from the researcher appended a letter from the general manager of Krishi Utsho explaining the agreement between Krishi Utsho and the researcher to conduct this study, and it stated the goal of the research, the expected outcomes and it thanked the 
participants in advance. The research participants all signed an informed consent form before they could be interviewed.

We reviewed all archival, process and research data available on Krishi Utsho. We also collected and analyzed any relevant secondary sources of information on Krishi Utsho and on the research question and theories of interest for this study. In total, we reviewed thousand pages of documents on Krishi Utsho and on the research questions and theories.

\section{V.2 Data analysis}

We followed Miles, Huberman and Saldana's (2013) advice to concurrently interweave data collection and data analysis from the start. We also followed their guidance on the three iterative steps in data analysis, including (1) data condensation, (2) data display, and (3) conclusion drawing/verification (Figure 4). Data condensation, also known as data reduction, is "the process of selecting, focusing, simplifying, abstracting and transforming the data that appears in the full corpus of written-up field notes, interview transcripts, documents, and other empirical materials" (2013, p12). To that end, we kept a complete repository of primary and secondary data, and we generated codes according to key constructs identified in the theoretical framing, developed themes, identified categories, and wrote analytical memos and summaries. Data condensation helped us to sharpen, sort, focus, discard, and organize data in such a way that final conclusions were drawn and could be verified.

Data display is "an organized, compressed assembly of information that permits conclusion drawing and action" (Miles et al., 2013, p12). To support this analysis step, we used graphs, tables, and flowcharts to visualize the most significant findings from our data. Using a graphic representation similar to the one used by Dhanaraj and Parkhe (2006) 
helped us understand how the microfranchise network is designed and orchestrated and how it is similar or different from the one presented in our theoretical framework. In the two steps above, we made good use of Nvivo software to condense, code, display and interpret our data.

The final data analysis step of drawing conclusions and verification, includes “identifying patterns, explanations, causal flows and propositions from available data" (Miles et al., 2013, p13). We held our conclusion lightly, maintaining openness and skepticism until we were confident our conclusion was verified thoroughly and consistent with our data and our findings.

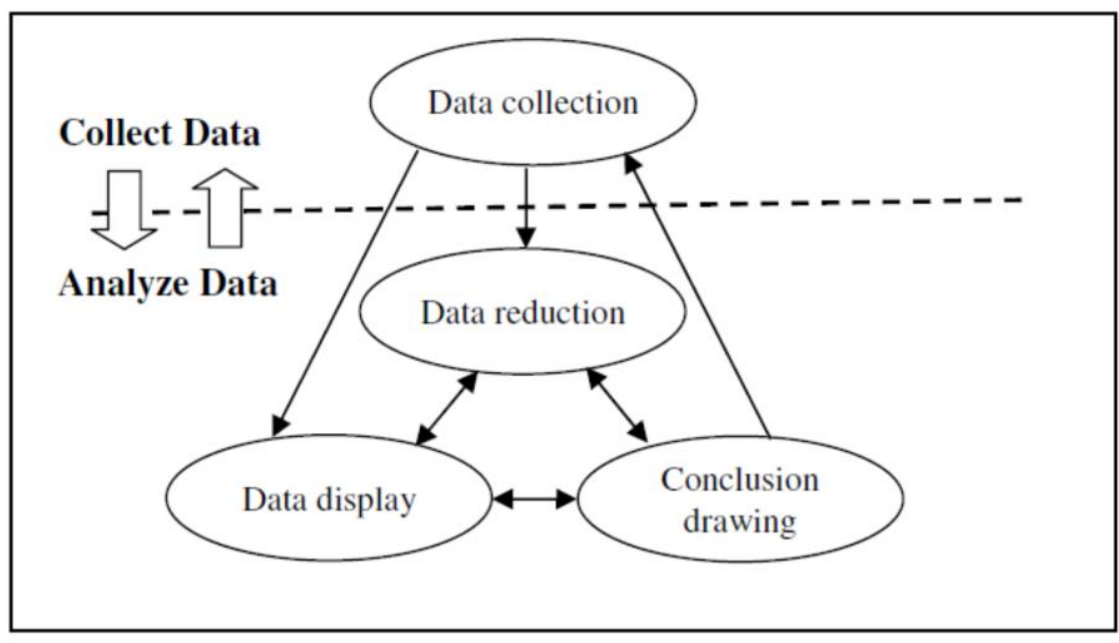

Figure 4: Approach to Data Analysis (adopted from Singh, 2011)

\section{V.3 Coding Data}

To code our data, we developed a coding scheme based on our theoretical framework, which in this case involved the orchestration of innovation network theory, as well as network imprinting theory. We also drew from the bottom of the pyramid and microfranchise literature, which is our area of concern, to inform our coding scheme. We 
borrowed from the six principles of coding proposed by Cousins et al. (2007) to develop and test our coding scheme. The six principles are:

1. Each quote must be self-contained and as brief as possible. In other words, the quote should be concise yet expansive enough that it does not require additional interpretation in order to code it.

2. Do not include all possible quotes. Code selectively to include quotes that:

a. speak directly to the theory, or

b. have high relevance to the case.

3. Strive for consistent coding practices.

4. Apply a 2-pass coding scheme:

a. $\quad 1^{\text {st }}$ pass: code among 4 high-level constructs (e.g. 1.0, 2.0, 3.0, 4.0)

b. $2^{\text {nd }}$ pass: assign low level codes (e.g. 1.1, 2.2, etc.).

5. Where applicable, use multiple codes.

6. Apply role code to the speaker only. For example, if one role speaks about another role (or another's view), this is captured by coding the speaker role only.

First, we worked closely with our dissertation principal advisor over the summer of 2015 on three occasions to identify, discuss, and agree upon an initial coding scheme (Miles \& Huberman, 1994) based on orchestration of innovation network and imprinting theories. We also included the bottom of the pyramid as well as a microfranchise stream of literature. The coding scheme we developed includes all the key themes, concepts and subconcepts found in the two theories. We provided detailed definitions of each sub-concept in Table 4. 
Second, after developing this initial coding scheme, we test piloted our coding scheme. My research advisor and I independently coded a sample interview from the empirical data we collected. We then discussed and fine-tuned our coding scheme and resolved any disagreements along the way. This process helped solidify our coding scheme and increased our confidence. 
Table 4: Coding Scheme

\begin{tabular}{|c|c|c|c|}
\hline Themes & Concept & Sub-concept & Definition \\
\hline \multirow{3}{*}{$\begin{array}{l}\text { Network } \\
\text { Design } \\
1.0\end{array}$} & $\begin{array}{l}\text { Network membership } \\
1.1\end{array}$ & $\begin{array}{l}\text { Network size } \\
\text { Network diversity }\end{array}$ & $\begin{array}{l}\text { Network membership defines the size and } \\
\text { diversity of the network and the value and } \\
\text { knowledge potential to its members. } \\
\text { Membership can be captured in rules about } \\
\text { who can and cannot join the network. }\end{array}$ \\
\hline & $\begin{array}{l}\text { Network structure } \\
1.2\end{array}$ & $\begin{array}{l}\text { Network density } \\
\text { Network autonomy }\end{array}$ & $\begin{array}{l}\text { Density is about the degree of formal or } \\
\text { informal relations amongst the members. } \\
\text { Autonomy refers to the degree to which } \\
\text { members can take actions without the } \\
\text { permission of someone in control of the } \\
\text { network. Autonomy impacts the degree to } \\
\text { which members can affect network structure. }\end{array}$ \\
\hline & $\begin{array}{l}\text { Network position } \\
1.3\end{array}$ & $\begin{array}{l}\text { Centrality } \\
\text { Status }\end{array}$ & $\begin{array}{l}\text { Centrality, confidence and status ascribed to } \\
\text { the hub by the network members. } \\
\text { These qualities are primarily reflected in the } \\
\text { network members' perception of the hub's } \\
\text { performance as network designer and } \\
\text { orchestrator. }\end{array}$ \\
\hline \multirow{3}{*}{$\begin{array}{l}\text { Network } \\
\text { Orchestration } \\
2.0\end{array}$} & $\begin{array}{l}\text { Managing knowledge } \\
\text { mobility } \\
2.1\end{array}$ & $\begin{array}{l}\text { Knowledge management } \\
\text { absorption } \\
\text { Network identification } \\
\text { Inter-organizational socialization }\end{array}$ & $\begin{array}{l}\text { The ease with which knowledge is shared, } \\
\text { acquired and deployed within the network. }\end{array}$ \\
\hline & $\begin{array}{l}\text { Managing innovation } \\
\text { appropriability } \\
2.2\end{array}$ & $\begin{array}{l}\text { Trust } \\
\text { Procedural justice } \\
\text { Joint asset ownership } \\
\end{array}$ & $\begin{array}{l}\text { Ensuring value created is distributed equitably } \\
\text { and perceived as such by network members. }\end{array}$ \\
\hline & $\begin{array}{l}\text { Managing network } \\
\text { stability } \\
2.3\end{array}$ & $\begin{array}{l}\text { Enhancing reputation } \\
\text { Lengthening the shadow of the } \\
\text { future } \\
\text { Building multiplexity }\end{array}$ & $\begin{array}{l}\text { Prevent network to become eroded, } \\
\text { disintegrated and ensuring network dynamic } \\
\text { stability }\end{array}$ \\
\hline \multirow[t]{2}{*}{$\begin{array}{l}\text { Network } \\
\text { Performance } \\
3.0\end{array}$} & $\begin{array}{l}\text { Hub firm } \\
3.1\end{array}$ & & $\begin{array}{l}\text { The performance of the lead firm orchestrating } \\
\text { the network. Key performance metrics are } \\
\text { timeliness and quality of services delivered by } \\
\text { hub firm to network members. }\end{array}$ \\
\hline & $\begin{array}{l}\text { Network innovation } \\
\text { output } \\
3.2\end{array}$ & & $\begin{array}{l}\text { This is the result of the network innovation } \\
\text { such as technological innovation, financial } \\
\text { returns, process improvement, and impact on } \\
\text { targeted population. }\end{array}$ \\
\hline \multirow[t]{3}{*}{$\begin{array}{l}\text { Network } \\
\text { Imprinting } \\
4.0\end{array}$} & $\begin{array}{l}\text { Alternate Network } \\
4.1\end{array}$ & $\begin{array}{l}\text { Weak tie } \\
\text { Moderate tie } \\
\text { Strong tie }\end{array}$ & $\begin{array}{l}\text { This includes past and current ties, formal and } \\
\text { informal. }\end{array}$ \\
\hline & $\begin{array}{l}\text { Structural position } \\
4.2\end{array}$ & $\begin{array}{l}\text { Dominant position } \\
\text { Lower position } \\
\text { Bridging position }\end{array}$ & $\begin{array}{l}\text { This is the position of the network members in } \\
\text { alternate network. }\end{array}$ \\
\hline & $\begin{array}{l}\text { Network persistence } \\
4.3\end{array}$ & $\begin{array}{cc}\text { Level of change in: } \\
- & \text { Behavior } \\
- & \text { Practice } \\
\end{array}$ & $\begin{array}{l}\text { Level of change (behavior and practice) } \\
\text { between previous network and new network } \\
\text { established }\end{array}$ \\
\hline \multirow[t]{3}{*}{$\begin{array}{l}\text { Content } \\
5.0\end{array}$} & $\begin{array}{l}\text { BOP } \\
5.1\end{array}$ & $\begin{array}{l}\text { Poor farmer } \\
\text { Illiterate } \\
\text { Marginalized } \\
\text { Vulnerable } \\
\end{array}$ & $\begin{array}{l}\text { People living at the base of the economic } \\
\text { pyramid. They are usually the poor making } \\
\text { less than } \$ 2 \text { per day }\end{array}$ \\
\hline & $\begin{array}{l}\text { Microfranchising } \\
5.2\end{array}$ & $\begin{array}{l}\text { Microfranchisors } \\
\text { Microfranchisees }\end{array}$ & $\begin{array}{l}\text { A variant of franchising but with focus on } \\
\text { achieving social impact as well as scaling up } \\
\text { entrepreneurship at the base of the pyramid }\end{array}$ \\
\hline & $\begin{array}{l}\text { Speaker } \\
5.3\end{array}$ & $\begin{array}{l}\text { CARE/Krishi Utsho staff, } \\
\text { suppliers, } \\
\text { Franchisees or shop owners } \\
\text { Partners, and Others }\end{array}$ & These are the people interviewed. \\
\hline
\end{tabular}


Third, we discussed how to use our coding scheme and coded a sample of interviews in order to further refine our coding scheme and reach the acceptable level of inter-coder reliability (using Cohen's).

Fourth, my advisor and I manually coded three samples of our interview transcripts and compared notes and calculated the inter-coder reliability. We coded transcripts of the interview from a Krishi Utsho staff, a franchisee and a supplier. In our first attempt, we reached an inter-coder reliability of 57\%. After further refinement of the coding schemes and two other attempts, we increased the inter-coder reliability to $90 \%$ which is above the $88 \%$ level recommended by Cohen. With this high level of inter-coder reliability achieved, we fine-tuned our coding scheme. The final coding scheme developed (Table 4) was then created in Nvivo 10. Each of the transcripts was imported into Nvivo 10 and coded according to the scheme. Any contextual information that did not fit the theoretical framework was also identified. 


\section{ANALYSIS AND RESULTS}

In this chapter we report the analysis of our empirical data as well as all the secondary data. We organize this chapter in four sections following the four temporal stages identified during the analysis of our data. We summarize the findings following our theoretical framework in a table after each stage.

\section{VI.1 2010-2012: Ideation and Creation}

The idea of creating a microfranchise network to provide timely access to quality and affordable agriculture input and services to the dairy BOP farmers in Bangladesh emerged in late 2010, two years after CARE started implementing the Strengthening the Dairy Value Chain (SDVC) project with funding from the Bill and Melinda Gates Foundation. The SDVC project aims at improving the livelihoods of 35,000 rural BOP farmers, who are small holder and landless households in nine districts of north and northwest Bangladesh, by enhancing their participation in and profit from the dairy value chain.

\section{VI.1.1 Challenges faced by BOP farmers:}

To achieve the goal of the five year SDVC project, which later was extended for another four years (2008-2016), CARE had to find innovative solutions to ensure that BOP

farmers have timely access to quality and affordable dairy input and services on a sustainable basis. The microfranchise network came about after a number of trial and errors attempted by CARE to solve the systemic constraints faced by the BOP farmers in Bangladesh. BOP dairy farmers particularly needed access to four types of inputs: (1) quality products such as feed and medicines for their livestock; (2) services such as animal 
health care and artificial insemination; (3) long-term services such as improved breed development, and (4) financial services.

\section{VI.1.2 CARE's early trial and errors}

CARE attempted many solutions to address the issues. One significant attempt was training community veterinarians-which CARE baptized as Livestock Health Workers (LHWs). These LHWs are community members with a high school degree who are trained on animal health issues and act as the first line of response before a professional veterinarian can be reached. They provide service on fee basis and carry feed and other animal health products that BOP farmers could avail. CARE also trained women in the community who sell door to door to be part of the dairy input distribution. A special threewheeled bicycle was commissioned to enable women to transport feed, but they could not sell enough volume to keep them interested in the new venture. Many other approaches were used by CARE to solve the systemic issues faced by BOP farmers, but none of them worked as expected. According to Kevin McKague and Siddiquee Muhammad (2014), "CARE attempted multiple, simultaneous initiatives to bring feed and medicines to farmers, but their early attempts met with little success. In the first two years of the project, all of CARE's experiments failed to make quality balanced feed rations available and accessible to smallholder farmers."

The failure of the trials conducted by the SDVC project staff did not discourage them from continuing to look for other possible ways to provide timely access to quality and affordable input and services to the BOP farmers. In the words of the CARE USA Senior Technical Advisor who provided technical assistance to the project in Bangladesh, 
"as we began to train more producers, there was increase in demand... we quickly found that entrepreneurs were stepping in opening shops near our project intervention areas. Some of them are input shop owners; others are LHWs who we trained. Hence, we ended up with a large universe of players who are suddenly interested in selling input to BOP farmers in our project area." This was a good indication that a market was developing organically based on project efforts. This spurred attention and discussion among CARE staff.

\section{VI.1.3 Early stage assessment and results:}

CARE conducted a detailed assessment of the emerging model to understand the opportunity and how it could be leveraged. As stated by the Senior Technical Advisor, "we undertook a very detailed assessment of the input suppliers. We mapped out their strengths and weaknesses. We covered over 150 livestock input providers. From this, we decided to hone in on a specific model closer to the behavior we would like to promote. Part of the model we had in mind was to develop a standard protocol for efficiency, quality, aggregation, branding and common marketing platform."

Initially though, CARE did not think of a franchise model. The assessment uncovered four major challenges that the emerging input suppliers faced. The first challenge was low quality of the feed and medicine. Many input providers abused their customers and were driven by higher profit. In the words of one franchisee member of the network, "many practitioners lure farmers with different low quality products. I try to convince farmers about the quality of my products. The price is higher, but the product is

better." The national and multinational companies in the agriculture input supply chain in 
Bangladesh also recognized this low quality product issue as one of their top challenges. One multinational company executive in the agriculture input business indicated that "many local companies just don't care about the quality of their products and the long term value of their companies. Most of them have unethical practices and offer cheap products for low quality to farmers. Worse, the Government does not have a quality control system in place." Addressing this low quality issue is part of the Krishi Utsho's vision as confirmed by the Manager of the network, "our vision is very simple. It is making quality agro-input products accessible to marginalized farmers in Bangladesh." The second challenge was lack of trust. As a result of the low quality products which dominated the market, there was a lack of trust between BOP farmers and the input providers since the BOP farmers are, in majority, illiterate and cannot differentiate quality feeds and medicine from those which are counterfeited. The third challenge was a fragmented supply chain, especially for feed and other non-medical products between the input providers at the community level and the private sector firms with inefficiency and lack of economies of scale. Finally, the fourth challenge was professionalization and long-term viability of the small-scale shops as they often lacked the adequate working capital, training in bookkeeping, basic business management, customer service and marketing.

At the same time, the CARE team found that there were opportunities that could be leveraged to address the major constraints and ensure timely provision of quality and affordable agriculture input and services to BOP farmers. One important opportunity that could be leveraged was the fact that CARE is embedded in the local communities, has a well-known brand which makes CARE a trustworthy player with the BOP farmers, the input suppliers, the shop owners and the society at large. Another opportunity was the 
recent creation and spin off of a similar social enterprise in Bangladesh by CARE and Danone called "Jita", which is a network of sales women going door to door to sell fast moving consumer goods using a hub and spoke model and a franchise-type approach to brand all the sales women in the same fashion and to standardize their operations. At the same time, CARE USA, which is the legal entity on which the office in Bangladesh depends, also created a separate for profit entity called CARE Enterprise Inc. as a holding company for social enterprises CARE creates around the world. The combination of these two ventures inspired the CARE SDVC project team to create a sustainable mechanism to provide quality and affordable input to BOP farmers outside of the life of the SDVC project. As final and obvious opportunity, there was a growing demand among BOP farmers for quality products and the goal pursued by CARE in its SDVC project was to double the income of the selected BOP farmers. Table 5 summarizes challenges and opportunities uncovered during the assessment.

\section{Table 5: Challenges and opportunities identified during the assessment}

\section{Identified challenges}

- Low quality agriculture input and services

- Lack of trust between BOP farmers and community input suppliers

- Fragmented supply chain, especially for feed and non-medical products

- Lack of professionalization and long term viability of shop owners due to inappropriate working capital, weak capacity of shop owners in management, marketing and customer services

\section{Identified opportunities}

- CARE's embeddedness in local market and good reputation

- Recent creation of a social enterprise spinoff entities by CARE in Bangladesh and CARE Enterprise Inc. by CARE USA

- Growing demand for quality agriculture input among BOP farmers

- CARE's mandate to double the income of dairy BOP farmers and extend a timebound project

\section{VI.1.4 Ideating and creating the early stage business model:}

The better understanding of the challenges and opportunities by CARE's staff generated brainstorming and ideation of a business model that could be put in motion. As recounted by the Deputy Manager of the network who joined CARE around the same time the network was created, "we were thinking of mechanism to deliver timely and quality 
input to the BOP farmers and to be able to cover operational costs and make some profit. From that idea, there were few options that were in front of CARE: establish our own shops or adopt the JITA hub-spoke model. So after evaluating every idea, we found that the franchise network would be most effective for a business environment like Bangladesh. Because in that case what Krishi Utsho has to do is to show competitive advantage over others, so it has to establish some control mechanism over the franchisees and then be a social enterprise which can run on its own." The Senior Technical Advisor of CARE USA was the most influential person in inspiring the project team and other stakeholders in CARE to consider the franchise model. He had prior experience from conducting an indepth assessment of a similar microfranchise model in the health sector in Kenya and he had also contributed a book chapter on the model.

Hence, in early $2011 \mathrm{CARE}$ decided to create a microfranchise pilot within the SDVC project. CARE submitted a business value proposition and a funding request to a small family foundation in April 2011 in Atlanta, USA to complement funding from the Bill and Melinda Gates Foundation provided to the SDVC project. CARE also submitted an application to the MAP program of the Ross School of Business of the University of Michigan in late 2011 to get support from MBA students to further study and conceptualize the franchise model given this was the first time CARE embarked on such venture and its novelty in the BOP context in Bangladesh. Both proposals submitted by CARE were approved which gave the CARE team the impetus to start a small pilot within the SDVC project.

The CARE team took a "learning by doing" approach to design and orchestrate the microfranchise network. The study conducted by the MBA students from the University of 
Michigan was very helpful in analyzing the landscape; hearing from the potential franchisees and suppliers and the BOP farmers; and, helping to refine the microfranchise concept. As a result, the CARE team carefully considered how to design the microfranchise network so it was scalable from products and services portfolio as well as geographical expansion perspectives.

Designing a brand and selecting a name that sent a strong message to farmers in Bangladesh about the quality and reliability of the network was also part of the early activities. The CARE team, with the help of professional consultants, designed nine different logos with different names, collected feedback from more than 200 farmers and shops owners, and refined the logos and names focusing on the ones that represented the ideal of what farmers wanted to see in the network. The selected logo is an iconic symbol of trust to signal to the market that the microfranchise network cares strongly about quality and reliability in a crowded market place where counterfeited animal products and medicines are the norm. The logo was also chosen because it would be difficult to imitate, which was an important consideration in a country with few protections on intellectual property. The branding adopted by the CARE team with input from potential franchisees also meant to signal that the shops are part of a larger infrastructure that goes beyond their individual footprint. The name Krishi Utsho in Bengali, which is the national language of Bangladesh, means "Agri-source". The name symbolizes a place where BOP farmers can find a variety of quality agriculture products and services, not only for livestock. As represented on the logo, there are fish, poultry, crop and other types of agriculture input along with livestock on the logo. 


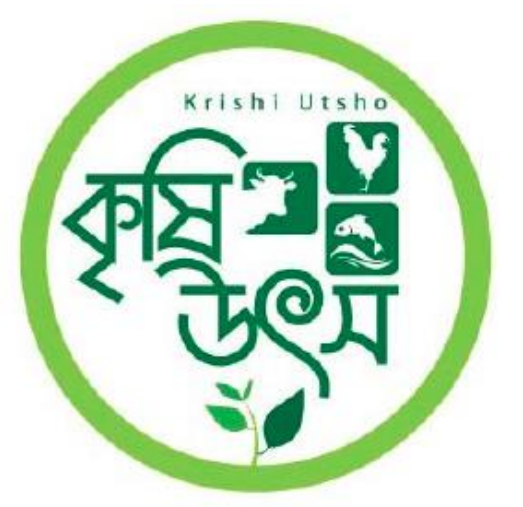

Figure 5: Krishi Utsho logo, photo credit of Krishi Utsho

The key network design, network orchestration, network performance and network imprinting characteristics of this first episode are summarized in Table 6.

Table 6: Innovation Networking during the Ideation and Creation Stage

\begin{tabular}{|c|c|c|c|}
\hline $\begin{array}{c}\text { Network } \\
\text { Design }\end{array}$ & Network Orchestration & Network Performance & $\begin{array}{l}\text { Network } \\
\text { Imprinting }\end{array}$ \\
\hline $\begin{array}{l}\text { - Initial assessment as } \\
\text { basis for network } \\
\text { design } \\
\text { - Better understanding of } \\
\text { challenges faced by } \\
\text { BOP farmers and } \\
\text { opportunities for } \\
\text { innovative solutions } \\
\text { - Development and } \\
\text { approval of value } \\
\text { proposition and } \\
\text { funding proposal } \\
\text { - Development of logo } \\
\text { and branding }\end{array}$ & $\begin{array}{l}\text { - There was no } \\
\text { network } \\
\text { orchestration at this } \\
\text { stage }\end{array}$ & $\begin{array}{l}\text { - First goal was timely } \\
\text { access to quality and } \\
\text { affordable livestock } \\
\text { input and services for } \\
\text { BOP farmers } \\
\text { - Second goal was } \\
\text { financial viability of } \\
\text { the network and its } \\
\text { members }\end{array}$ & $\begin{array}{l}\text { - Lack of trust } \\
\text { between BOP } \\
\text { farmers and } \\
\text { suppliers (firms and } \\
\text { shop owners) } \\
\text { - No prior experience } \\
\text { in designing and } \\
\text { orchestrating a } \\
\text { microfranchise } \\
\text { network at CARE. } \\
\text { - Input shop owners } \\
\text { and suppliers not } \\
\text { organized in any } \\
\text { formal network } \\
\text { - LHWs network was } \\
\text { tapped to be part of } \\
\text { the microfranchise } \\
\text { network }\end{array}$ \\
\hline
\end{tabular}

\section{VI.2 2012-2013: Development and Launch}

Based on a strong logo and branding, a tested value proposition, and approved funding for the Krishi Utsho microfranchise network, the SDVC Project Management tasked a team of ten people within the SDVC project staff to further develop the concept 
and launch the network in 2012. Hence, staying true to the "learning by doing" approach, the SDVC team did not wait to develop a fully-fledged business plan and to secure all the required funding before launching a small pilot under the auspices of the SDVC project. Accordingly, the team mobilized all resources and assets they could get to support the development and launch of the network.

\section{VI.2.1 Recruiting the first fifteen franchisees:}

The first task was the selection of the first fifteen shops among the over 150 shops surveyed and convert them as franchisees as part of the Krishi Utsho microfranchise network. The team thought fifteen shops was a reasonable number to start with and learn from to demonstrate proof of concept. The team made an important decision to start the pilot in Bogra and Rangpur districts which are affluent dairy hubs in Northern Bangladesh. Both were also an important geography in the SDVC project. This decision made it somewhat easier for the SDVC team to narrow down the list of shops. Other criteria used to select the first shops were:

1. Have an existing outlet in the targeted geographical location

2. Be a trained livestock health worker

3. Carry feed and medicine in demand by the targeted BOP farmers

4. Shop located in an easy proximity to BOP farmers participating in the SDVC project

5. Interest in joining the microfranchise network and being compliant of its rules.

Krishi Utsho continued to refine its value proposition for the prospective franchises as well as for suppliers, the BOP farmers and current and future funders in the development and launch stage. Most specifically for franchisees, Krishi Utsho's proposal was four fold. First, facilitate a better access to a wide range of quality and cost-effective agriculture input 
and services suppliers, not only for dairy livestock, but also fishery, poultry, crop protection and seed, financial services and agriculture equipment. Second, strengthen the input and services supply chain to make it more efficient and inclusive and drive down cost to ensure competitive prices to BOP farmers. Third, invest continuously in training and knowledge sharing to enhance the technical capacity of the franchisees to provide quality services to BOP farmers and to professionally manage their business. And finally, build and grow a strong customer base for the franchisees to increase their sales volume and profit.

Once the shop owners were selected, the SDVC team conducted a baseline study to further assess their understanding and practice of key concepts including business promotion, record keeping, basic business operations, inventory management, quality standards, distribution channels and linkages with agro-input suppliers and their readiness to be converted. This information helped generate a business profile of each of the sampled candidates and fed into Krishi Utsho's capacity building plan. The selected shops were then classified in three categories: category A was shops with great potential who can convert within one to two month; category B shops met most of the criteria and could convert in less than three months; and, category $\mathrm{C}$ shops needed up to six months to convert. Once the shops were selected, they were included in the network, even without being branded, and Krishi Utsho started doing business with them. This built their capacity to get ready for conversion and assessed their readiness via a formal assessment. As testified by one of the franchisees, "I was working in the old shop. My level was not good. Krishi Utsho took time to see how I was improving. This was the testing period. It is like gold when you take time to understand its purity. Similarly, Krishi Utsho took the time to get to know me and assess if I can join the network." Figure 6 depicts the selection and 
conversion process of candidate franchisees that Krishi Utsho followed. The shops also had to come up with some financial commitment to invest in improving their business, increase their inventory with the anticipated growing demand, and comply with the layout and branding protocol. In many instances, the shops had to move to another more appropriate store to meet the franchise format introduced by Krishi Utsho (see photos below).

Working alongside the franchisees, the SDVC team used the opportunity to get a better understanding of key products in demand by the BOP farmers, key suppliers of the shops, and categories of products. Quality standards were an important consideration for the SDVC team to ensure that only products on the shelves of the franchisees met the required quality because of the major concerns expressed by the BOP farmers and mistrust uncovered during the design phase. The SDVC team also used the opportunity to get to know the suppliers of the shops, to develop a data base, and to start building relation with some of them at the district level as well as at their respective headquarters. This enabled the SDVC team to develop an engagement plan with the major suppliers.

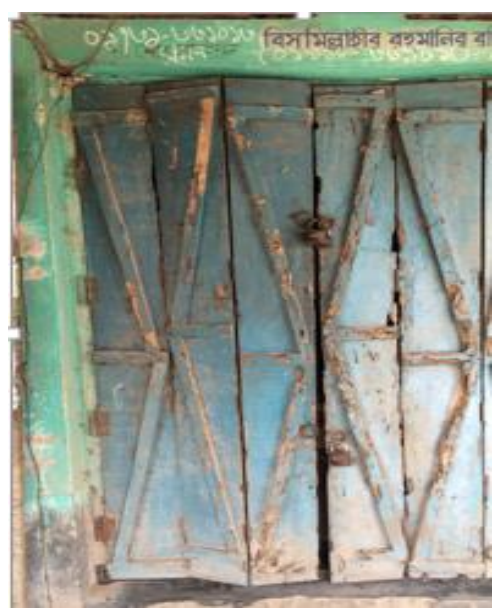

Figure 6: Before conversion into Krishi Utsho, photo credit from author 


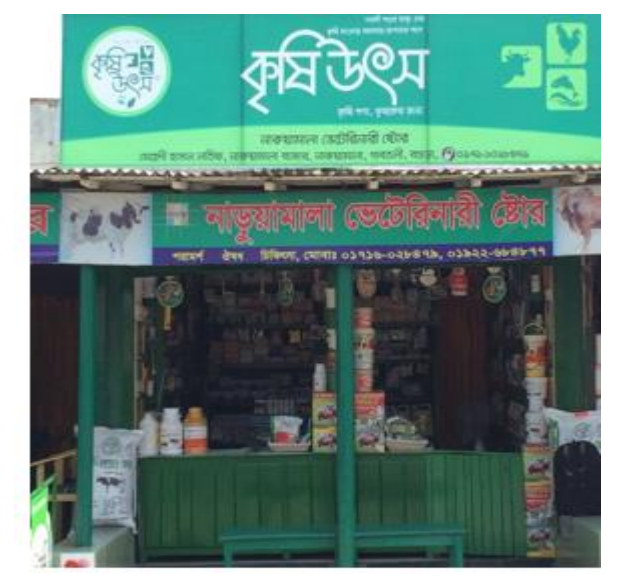

Figure 7: After conversion into Krishi Utsho, photo credit from author

\section{VI.2.2 Recruiting supplier firms:}

Given the low quality issue in the sector and the high commitment by Krishi Utsho to quality standards, the hub firm had to meticulously identify and recruit top brand firms that could act as suppliers of products and providers of services to the network. To select those suppliers, the SDVC team developed criteria to meet the multiple goals pursued by the network. They were: (1) quality of the products; (2) firm's reputation; (3) firms 'ability to provide services like veterinary training to franchisees, and financial incentives such as commission to the hub firm; and (4) franchisees' ability to get product at a competitive price. Ultimately, the SDVC team, acting on behalf of Krishi Utsho as the hub firm, also kept in mind the interest of the BOP farmers. They used a very detail due diligence process to select the top reputable national and multinational firms to become members of the network as suppliers and providers of services. The team collected publically available information on the firms and when needed, with the help of CARE Corporate Engagement Department in Dhaka, the team conducted independent laboratory tests to ensure that the 
quality of the product is up to standard. The team specifically took this approach with the feed companies and relied mostly on rating conducted by government entities and others industry bodies with animal medicinal products.

Conversely, building trust and making a strong value proposition with suppliers were also very important as most of them, especially the animal medicine firms already had a very robust distribution channel in place and conducted business with many of the shops and other competitors such as pharmacies in the same area covered by Krishi Utsho. The SDVC team had to make the case that new demand is being generated with BOP farmers who were trained by CARE as part of the SDVC project and were now aware of the need for quality product. The team also had to demonstrate that many new shops had emerged as a result of the increased demand for quality products. Arguing for efficiency gains and cost reduction for the suppliers by virtue of working with Krishi Utsho was also part of the negotiation process. To convince medicine and feed firms to agree to join the network, the SDVC team emphasized during the negotiations that the franchisees were committed to uphold the highest quality standards and that they would not prescribe expired medicines or counterfeited products. The team traded carefully to protect the new emerging opportunity the network was creating. This fear was shared by the Manager of the network in these terms: "suppliers and manufacturers are bigger than Krishi Utsho. We are careful they don 't grab our business. "Without a proof of concept, however, it was difficult for Krishi Utsho to recruit suppliers into the network. Nevertheless, with CARE's reputation in Bangladesh and the value proposition developed, the SDVC team managed to recruit three reputable national animal medicine firms as well as one feed company. One success in the negotiation was the agreement the team secured with a feed company to meet 
all the required quality standards of the network, to brand the feed with Krishi Utsho logo and make smaller packages to meet the purchasing power of the BOP farmers. 
Step 1: Pre-screen and in-depth survey of a pool of shops franchisees in targeted geographies

- Value proposition from Krishi Utsho and discussion of shop's interest to join the network

- Pre-screen to select a pool of shops who meet most of the criteria

- In-depth assessment to narrow down the list of shops who meet the selection criteria

Step 2: Second round of assessment \& rating of the shops

In-depth assessment of the shops and rating, A, B and C

Conversion plan developed based on rating

Exit of shops who do not meet the criteria or classified A, B or C

Step 3: Development and implementation of training and coaching plan based on shop's rating

Training provided by Krishi Utsho on microfranchise operation, business management and technical skills

Tailored coaching plan developed and implemented

Step 4: Final assessment of readiness for conversion to franchisee

Performance assessment based on training and coaching plan

Determination of shop's readiness to convert

\section{Step5: Conversion into branded Krishi Utsho franchisee}

Physical change of the shop and branding: painting in the distinct green and white franchise color, installing external and internal signage, and displaying Krishi Utsho branded posters and information boards.

Inauguration of the branded shops

\section{Figure 8: Franchisee's selection and conversion process modified by author}

\section{Initial launch and early stage orchestration of the network:}

To launch the network at its initial stage, the SDVC team had structured it to balance the autonomy of the network members while ensuring adherence to the rules of the game and the long term vision of the network. For instance, the SDVC team adopted a flexible conversion franchise model which allowed franchisees to continue to buy products from their current suppliers as long as they conformed to the established quality standards.

Franchisees were only selling medicine products prior to joining the network. They also carried other medicinal products such as vitamin, concentrate and premix. The team was 
conscious that it could not substitute immediately all functions fulfilled by the suppliers in the network and the extra services they were providing such as veterinary services and valuable knowledge on product handling and disease detection. One main reason for this flexibility was that many medicine firms had and still have well-developed and robust distribution channels in place and have had prior relation with the franchisees. This flexibility kept the formal and the informal tie that existed between the suppliers and the franchisees in place. Franchisees also had the latitude to purchase medicine products from other firms beside the three recruited by the hub firm so long as the quality standards were met. Some franchisees indicated, however, that they would be happy to procure all their medicines from the hub firm. This is illustrated by one franchisee "I am completely willing to buy everything at 100\% at some point from Krishi Utsho.” The shelf space occupied by Krishi Utsho during the launch period for medicine products ranges between $10 \%$ and $20 \%$ according to the Manager of the network. This flexibility from Krishi Utsho was its way to signal to the network members that its priorities were creating increasing value.

\section{VI.2.3 Getting the first fifteen shops ready for conversion:}

The priority for Krishi Utsho at the Development and Launch stage was to work with the fifteen selected shops to get them ready to convert into the branded Krishi Utsho franchise network. Getting them ready involved training and coaching on topics ranging from microfranchise business operation, business management and technical knowledge in animal care and treatment. The training was offered individually as well as collectively. The later gave the opportunity to the candidate franchisees to get to know each other and develop stronger ties. 
The SDVC team also leveraged the technical expertise from the medicine firms who are members of the network, especially from their veterinarians, to provide technical training to the franchisees on various issues such as disease diagnosis, drug prescription, and treatment. As stated by one team member, "two things happened; franchisees can learn together with the expert how to diagnose disease and this also improved the demand side." In addition to the training, Krishi Utsho also requested the veterinarians to offer advice on best products that the franchisees should carry given the types of diseases in their community. One rule imposed by Krishi Utsho was to request the veterinarian to prescribe only the best products available in the market, not only from the veterinarian's firm. This procedure helped to build a range of products available in the network that BOP farmers could avail. It also helped to make knowledge mobile between medicine companies in the network, the franchisees and the hub firm. Hence, the network emphasized management of knowledge mobility as the success of the pilot hinged on the professionalization of the franchisees and the quality and the range of products they could offer the BOP farmers.

\section{VI.2.4 Creating demand for quality:}

In addition to focusing on the franchisees, the hub firm also extended its reach to the BOP farmers by organizing a weekly animal health fair in select communities in the vicinities of the fifteen franchisees. The hub firm was deliberate in inviting veterinarians from its member medicine firms in the network as well as veterinarians from the local government animal health department. BOP farmer communities received training and information on how to take better care of their dairy livestock. Feed preparation and administration, vaccination and de-worming campaigns were also organized during the health fair which gave the opportunity to the franchisees and the medicine and feed 
companies to promote their products and the Krishi Utsho microfranchise network. These weekly events were successful in raising the awareness of the BOP farmers to demand and access higher quality products and services for their dairy livestock. This generated increased business for the franchisees and the network. The event also provided the opportunity to Krishi Utsho to listen to BOP farmers in order to make the network more effective in meeting their needs.

One concrete opportunity that the network created to the BOP farmers was the integration between Krishi Utsho and the milk collection points with a view to offer payment facilities to farmers who cannot purchase the product in cash. BOP Farmers therefore had access to the products on credit and could pay back the franchisees when they received payment for their milk on a weekly basis. This innovation introduced by the hub firm created value not only for the BOP farmers but also for the dairy industry and the network itself. This increased the trust and the loyalty of the BOP farmers and the dairy collection points towards the network.

\section{VI.2.5 Structuring the network:}

From a contractual perspective, the hub did not formalize the relationship with the network members through any formal contract. The relation was informal. At launch, the hub prioritized the education of the franchisees and convinced them to accept and apply the terms and the quality standards of the network over legality. The hub aimed to achieve a proof of concept to facilitate diffusion of the network instead of locking its members in a legally binding relation at that early stage. In any case, it can be a daunting venture to enforce contracts in an embedded and poor setting such as rural Bangladesh with weak rule 
of law (de Soto, 2000). With the suppliers, the hub had a mixed approach. With some suppliers such as the feed company, it has formalized the relation through a contract. With the medicine company, the hub only had a letter of collaboration in place.

\section{VI.2.6 Getting the supply chain right:}

Getting the supply chain right was another important objective the network pursued at this early stage as many franchisees faced difficulties with timely access to the right quality inventories to serve their customers. However, given the well-developed distribution system that many medicine firms already had in rural Bangladesh, Krishi Utsho decided to let its franchisees continue to buy directly from them provided the quality standards were adhered to. This statement from one representative of a top medicine company in Bangladesh illustrates very well the situation: "with the advent of Krishi Utsho, we have not yet made any big change in our delivery system. Sometime we deliver through Krishi Utsho, but in a large extent we still continue to do business as usual directly with the shops." Nevertheless, the hub firm started to develop its in house supply chain system by setting up a small warehouse close to the franchisees in order to fill the supply gaps that some of them faced. The volume of medicine carried by the hub firm was very minimal at the early stage. However the branded feed with the Krishi Utsho logo was a new product and needed a more robust distribution system. Krishi Utsho managed the early stage warehouse system with challenges given the high standard CARE's policy regarding warehouse compliance in Bangladesh. To comply with CARE's rules, Krishi Utsho would have to make a substantial investment which it could not afford. 


\section{VI.2.7 Early stage challenges:}

Orchestrating the network at this early stage posed other additional challenges that the hub firm had to manage to maintain its stability. The challenges were three folds, out of which one was completely outside the control of the network. The first one was working capital. To convert, the franchisees needed an investment of about $\$ 3000$ on average. For many franchisees, this investment was difficult to fund. Although very small, this is a typical constraint found in the BOP market (Lehr, 2008). Having a healthy working capital became even important as demand started to grow and the franchisees and the franchisor needed to carry enough inventories to satisfy the demand. The credit facility to BOP farmers introduced by the network also added to the working capital issue. Unfortunately, the network did not have requisite financial resources to address the working capital issue, nor were the financial institutions in Bangladesh interested in financing the franchise network given its early stage and lack of proof of concept and scale. Krishi Utsho had to come up with some creative solutions, such as negotiating longer supplier credits with medicine and feed firms with some mixed results.

The second challenge was the low quality products. Although the awareness was raised for BOP farmers to demand higher quality products, many medicine and feed companies continued to dump counterfeited products in the market and offered higher margin to franchisees and the competition. This perverse incentive did not help the end consumers with the right products to treat or prevent diseases for their animals which, in many cases, are the main source of their cash revenue. Krishi Utsho had to step up its efforts to continue to educate the franchisees and the BOP farmers and work alongside the top brand companies to increase the margin to the franchisees. 
The third challenge was the political unrest. Early 2013 involved more than three months of political turmoil in Bangladesh with road blockades which paralyzed the entire supply chain not only for the Krishi Utsho business but also the entire economy in Bangladesh. BOP farmers could not sell their milk as dairy companies could not go to remote areas to collect milk. Franchisees could not get their inventories. This represented a serious threat to the emerging network. Krishi Utsho had found some creative way to get some minimum inventory directly and through its suppliers to the franchisees over the weekend and during night time when the situation allowed. Business was reduced to more than $3 / 4$ of the normal turnover.

\section{VI.2.8 Managing early stage imprinting:}

As mentioned above, the Krishi Utsho network was characterized by a significant level of imprinting that the hub firm had to manage carefully to demonstrate a proof of concept to be able to expand and create value. The imprinting of the network could be categorized in two, the positive ones that the hub firm strived to leverage to create value for its members and the negative ones that the hub firm managed with difficulties to get rid of. This also involved consideration of the level of relation or tie that existed between the network members prior to their joining the Krishi Utsho network. Three levels of ties were found among the members of the network, high, medium and weak.

A positive imprinting that Krishi Utsho leveraged included the existing strong tie between the franchisees and the suppliers. Because the suppliers were already doing business with the franchisees before they joined Krishi Utsho, this helped to maintain a smooth flow of the inventory from the medicine companies to the selected franchisees. A second positive leveraging of the imprinting was the strong tie that existed between the 
franchisees prior the establishment of the network since the majority of them were trained as LHWs by CARE and were part of the informal LHW association facilitated by CARE. This strong tie helped Krishi Utsho convey its value proposition to the association and its members and convince them to join the network.

On the flip side, it was difficult to change poor practices, especially as related to the fact that many franchisees were selling poor quality animal health products. The unprofessional management of the shops was another difficult habit that the new network struggled to change on the get go. For instance, many franchisees were not used to keeping record of financial transactions or maintaining customer registers. This made it difficult for the network to track the business performance of the franchisees and of the network as a whole.

\section{VI.2.9 Early performance:}

Despite all the challenges faced at its beginning, the network was able to show a strong performance that helped to build momentum among its stakeholders. First, in January 2013, Krishi Utsho was promoted for the first time in public during the 'Agro Technology Fair 2012' held at Bangladesh Agricultural University (BAU), Mymensing. This helped to increase the profile of the network and get attention from the government, businesses as well as donors. Second, on the business management front, the network designed a number of tools, including a mobile phone based application to enable data collection and analysis to monitor and manage the business performance of the franchisees and the network as a whole. Third, in August 2012, the SDVC team converted all the initial fifteen shops into a branded network of Krishi Utsho Microfranchise in Bangladesh. 
Fourth, in September 2012, Krishi Utsho made its first sale of about $500 \mathrm{~kg}$ worth of branded dairy cow feed to the franchisees. Fifth, nine months after the conversion of the shops into a branded franchise network, the fifteen franchisees showed on average a 50 percent increase in sales revenue. All the franchisees were able to break-even within twelve months of their conversion.

The key network design, network orchestration, network performance and network imprinting characteristics of this second episode are summarized in Table 7. 
Table 7: Innovation Networking during the Development and Launch Stage

\begin{tabular}{|c|c|c|c|}
\hline $\begin{array}{c}\text { Network } \\
\text { Design }\end{array}$ & Network Orchestration & Network Performance & $\begin{array}{l}\text { Network } \\
\text { Imprinting }\end{array}$ \\
\hline $\begin{array}{l}\text { Network membership: } \\
\text { - Development of criteria } \\
\text { and value proposition } \\
\text { for the selection of } \\
\text { initial shops and } \\
\text { suppliers } \\
\text { - Categorization of shops } \\
\text { in categories A, B and } \\
\text { C } \\
\text { - Fifteen shops selected } \\
\text { and converted into the } \\
\text { microfranchise network } \\
\text { in August } 2012 \\
\text { - Three medicine } \\
\text { companies and one } \\
\text { feed company selected } \\
\text { as suppliers to the } \\
\text { network } \\
\text { Network structure } \\
\text { - Krishi Utsho adopted a } \\
\text { flexible conversion } \\
\text { franchise model } \\
\text { Informal relation } \\
\text { between the hub and } \\
\text { the franchisees } \\
\text { Network Position: } \\
\text { Increased trust between } \\
\text { BOP farmers, milk } \\
\text { collection points and } \\
\text { the network because of } \\
\text { the three-way payment } \\
\text { system introduced }\end{array}$ & $\begin{array}{l}\text { Managing knowledge } \\
\text { mobility: } \\
\text { - Training and } \\
\text { coaching of } \\
\text { franchisees } \\
\text { - Organization of a } \\
\text { weekly animal health } \\
\text { fair event to educate } \\
\text { BOP and promote the } \\
\text { network } \\
\text { Knowledge } \\
\text { distributed by } \\
\text { leveraging the } \\
\text { expertise of medicine } \\
\text { and feed companies } \\
\text { as well as public } \\
\text { sector veterinarians } \\
\text { Managing innovation } \\
\text { appropriability: } \\
\text { - Introduction of a } \\
\text { three-way credit } \\
\text { facility for customers } \\
\text { which co-created } \\
\text { value for BOP } \\
\text { farmers, the network } \\
\text { and the dairy industry } \\
\text { Managing network } \\
\text { stability: } \\
\text { - Managing early stage } \\
\text { challenges to } \\
\text { maintain network } \\
\text { up with some } \\
\text { challenges } \\
\text { cability (working } \\
\text { product from } \\
\text { competition and } \\
\text { political unrest) } \\
\text { - }\end{array}$ & $\begin{array}{l}\text { - Krishi Utsho was } \\
\text { publically promoted in } \\
\text { January } 2013 \text { at the } \\
\text { "Agro Technology } \\
\text { Fair" } \\
\text { - Converted the first } \\
\text { fifteen fully branded } \\
\text { franchisees in August } \\
\text { 2012 } \\
\text { - First sale of feed to } \\
\text { the franchisees in } \\
\text { September } 2012 \\
\text { - Krishi Utsho } \\
\text { developed an IT-based } \\
\text { performance } \\
\text { management system } \\
\text { - Franchisees increased } \\
\text { on average their sale } \\
\text { by } 50 \text { percent within } \\
\text { nine months of joining } \\
\text { the network } \\
\text { - Franchisees reached } \\
\text { break-even point } \\
\text { within twelve months } \\
\text { of joining the network }\end{array}$ & $\begin{array}{l}\text { Alternate network: } \\
\text { - Krishi Utsho } \\
\text { leveraged the } \\
\text { positive and strong } \\
\text { tie that existed } \\
\text { between the } \\
\text { franchisees and } \\
\text { suppliers to ensure a } \\
\text { smooth supply chain } \\
\text { - Krishi Utsho } \\
\text { positively leveraged } \\
\text { the informal } \\
\text { association of the } \\
\text { LHWs to convey its } \\
\text { value proposition and } \\
\text { recruit them to the } \\
\text { network } \\
\text { Network persistence: } \\
\text { - Krishi Utsho } \\
\text { struggled to change } \\
\text { the bad franchisee } \\
\text { habit of carrying and } \\
\text { selling low quality } \\
\text { products } \\
\text { - Krishi Utsho } \\
\text { struggled to } \\
\text { introduce } \\
\text { professional business } \\
\text { management } \\
\text { practices to the } \\
\text { franchisees } \\
\text { - Krishi Utsho } \\
\text { struggled to meet the } \\
\text { high standard } \\
\text { CARE's policy } \\
\text { regarding warehouse } \\
\text { compliance. }\end{array}$ \\
\hline
\end{tabular}

\section{VI.3 2013-2014: Growth and Reconfiguration}

The strong performance demonstrated by the network gave the SDVC team confidence to press towards growing the network. The performance of the franchisees was particularly important to demonstrate proof of concept. The fifteen franchisees contributed 
to spreading the news about Krishi Utsho and how it transformed the way they do business.

This led to a high demand for becoming engaged among other agro-input shop owners in rural and peri-urban Northern Bangladesh. To capture the increasing demand and to continue to orchestrate the network, the team made some important decisions and took specific actions.

\section{VI.3.1 Formalizing the management of Krishi Utsho:}

The recruitment of an experienced Managing Director and the appointment of a dedicated team to focus only on growing and expanding Krishi Utsho were part of the SDVC team's strategic decision. The Managing Director, recruited in May 2014 after a long search and some adjustment to CARE HR policy, came from a leading telecommunication company in Bangladesh with 11 years of professional and management experience in supply chain, marketing and finance. He holds an MBA degree from a reputable university in Bangladesh. The dedicated team of eight was assigned these core functions: operations management; sales and distributions; business development; administration and finance management; information system; and, performance management. Enrolling this level of human resources into the hub to support the growth and the reconfiguration of the network was enabled by another grant received from the small Family Foundation out of Atlanta in 2014 and the second phase of funding received by the SDVC project from the Bill and Melinda Gates Foundation.

The Manager of the SDVC project had to bargain hard with the Human Resource (HR) Department and the leadership of CARE Bangladesh to be able to recruit the new Managing Director at a competitive salary which was outside of CARE's salary scale but 
comparable with the private sector market. This was an important persisting imprinting that the SDVC team had to deal with. The small Family Foundation out of Atlanta as well as the CARE USA team supported the case made by the SDVC team and convinced the CARE Bangladesh leadership to make the exception in the salary scale in order to bring the new Krishi Utsho Manager on board. Changing the job titles of the Krishi Utsho staff to give them a more commercial connotation contrary to development titles they carried was and remains a negotiation the hub is conducting with the CARE Bangladesh HR Department.

\section{VI.3.2 Recruiting additional members to the network:}

The new leadership of Krishi Utsho and the dedicated team added new franchisees and suppliers to the network. They also expanded the customer base and added new features and products to the network. Before adding new candidate franchisees though, the new Krishi Utsho leadership reflected on the success and challenges from the Development and Launch stage and made some changes to enable the network to expand on a stronger footing. One such change was the revision of the criteria for the selection of the candidate franchisees. The criteria were refined based on the experience gained and the lessons learnt from the first batch of franchisees who were converted into the network between 2012 and 2013. In the word of the Deputy Manager of the network, "in the first phase we did not find many interesting shops given our narrow geographical focus and lack of experience. We had to choose from the sample available to us, but the sample was with lower capability. In that sense we got only few business men. In the second phase, we reviewed our criteria and expanded the geographies to identify good potential shops, this helped very much... The sample was very good as a result." As testified by a franchisee that was 
converted into the network in this phase, Krishi Utsho used the following criteria to select him: "Honesty, sincerity, honorability and popularity in the community, ability to adjust to Krishi Utsho's business policy, ability to help the people, especially illiterate people and shop geographically well positioned in the market place." The Deputy Manager of the network who is also in charge of the operation and the expansion of the network added: "We consider personal trait and character, business transaction record with suppliers, cash position, credit worthiness, customer base and relation, supplier relation, investment capacity, specific experience in the business, background and education, linkage with different association, interest to work with Krishi Utsho and positive references from others."

These criteria were validated in Krishi Utsho's documents. Table 8 summarizes how the criteria evolved between the Development and Launch stage and the Growth and Reconfiguration stage. Personal character, strategic position of the shops in the market place, track record with suppliers, and the financial capability for additional investment were some of the criteria added to select the second batch of franchisees. By the end of 2014, Krishi Utsho counted forty eight franchisees in conversion and fifteen franchisees fully branded. 
Table 8: Evolution of selection criteria for franchisee

\begin{tabular}{|c|c|}
\hline $\begin{array}{l}\text { Criteria for franchisees' selection - Developme } \\
\text { and Launch stage } \\
\text { (2012-2013) }\end{array}$ & $\begin{array}{l}\text { Criteria for franchisees' selection - Growth and } \\
\text { Reconfiguration stage (2013-2014) }\end{array}$ \\
\hline $\begin{array}{l}\text { 1. Have an existing outlet in the targeted } \\
\text { geographical location }\end{array}$ & $\begin{array}{l}\text { Be honest, sincere, honorable and } \\
\text { maintain a good reputation in the }\end{array}$ \\
\hline Be a trained livestock health worker & community \\
\hline $\begin{array}{l}\text { 3. Carry feed and medicine in demand by the } \\
\text { targeted BOP farmers }\end{array}$ & $\begin{array}{l}\text { Shop strategically well positioned in the } \\
\text { market place }\end{array}$ \\
\hline $\begin{array}{l}\text { 4. Shop located in an easy proximity to BOP } \\
\text { farmers participating in the SDVC project }\end{array}$ & $\begin{array}{l}\text { Have a positive business track record with } \\
\text { suppliers }\end{array}$ \\
\hline $\begin{array}{l}\text { 5. Interest in joining the microfranchise } \\
\text { network and being compliant of its rules. }\end{array}$ & $\begin{array}{l}\text { 4. Be credit worthy and have financial } \\
\text { resources to invest to expand the business } \\
\text { 5. Have a strong customer base and positive } \\
\text { customer relation } \\
\text { 6. Have an experience in conducting agro- } \\
\text { input supply business } \\
\text { 7. Interested to join the Krishi Utsho } \\
\text { network and to serve BOP farmers } \\
\text { 8. Receive positive references from others }\end{array}$ \\
\hline
\end{tabular}

As for the suppliers, Krishi Utsho did not make any drastic change to the criteria or the process used in the Development and Launch stage. It, however, added three additional reputable medicine firms which brought the total number of medicine firms in the network to six. One firm is a multinational company with headquarters outside Bangladesh and the other five are Bangladeshi Headquartered, but with operations in several countries in Asia and Africa. Together the six companies control over $80 \%$ of the animal health market in Bangladesh. Krishi Utsho also added a couple of feed firms as suppliers. In total, by the end of 2014, Krishi Utsho had nine suppliers as part of its network (See Appendix 1 for details).

\section{VI.3.3 Addressing supply chain issues:}

An important change introduced by the network was outsourcing the supply chain management. Given the growth of the network and the challenge the network was up against in complying with the high standard and restrictive policy of CARE's internal warehouse and the cost associated with it, Krishi Utsho recruited a third party firm to 
manage the supply chain on behalf of the network. The thinking of the leadership team was that a third party provider would not need to comply with CARE's internal policy and could manage the supply chain more cost-effectively than having it in house. This was reflected in the words of the Managing Director of OSS, the third party firm recruited: "The major challenge for Krishi Utsho is that CARE's policy is very restrictive. It slows down the expansion of the business. OSS can help since it does not have this policy issue to support the whole network." Another rationale was that the team did not have requisite expertise yet and that it was important to start on solid ground to support the learning that comes with supply chain management. The third party company was recruited in early 2014 after a competitive bid and was given the mandate to set up warehouses at strategic locations and manage the procurement and distribution of the inventories from the selected suppliers to the franchisees. In the words of the Managing Director of the third party firm, "OSS is a supporting partner of Krishi Utsho. We help with warehousing, stocking, procurement, distribution, payment, in brief supply chain management." As of the end of December 2014, OSS was serving 56 fully branded and in conversion franchisees with 4 warehouses and a team of service personnel in each warehouse. OSS became an important player in the network helping to ensure a smooth inventory management and supply chain of the network. OSS also contributed to inject new ideas and innovation into the network given its technological background as a firm. One such influence was the promotion of a mobile phone based application to ensure timely inventory management.

\section{VI.3.4 Managing innovation appropriability:}

An important innovation introduced and promoted by the network was a product known to some dairy farmers but not commercialized in Bangladesh. In the quest for 
satisfying BOP farmers who complain about low fat content of their milk, which is one of the important factors in determining milk price in addition to volume and quality, Krishi Utsho was always searchingfor scalable solutions.

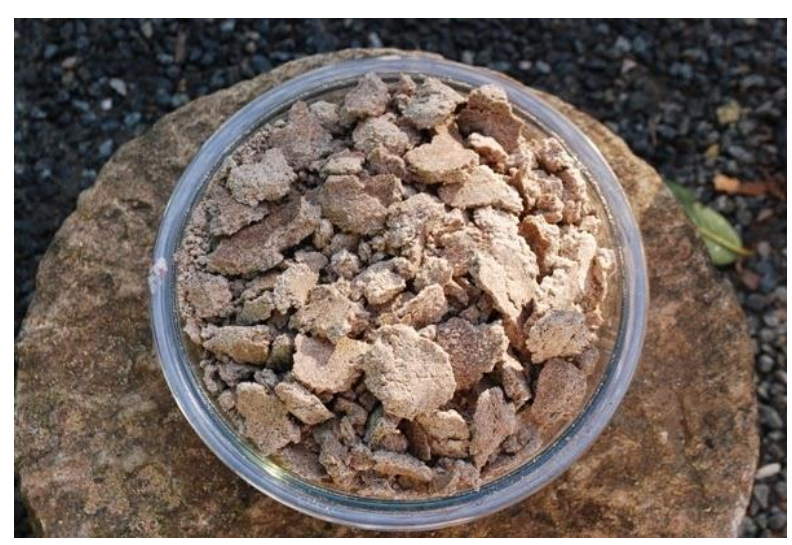

\section{Figure 9: Photo credit of Krishi Utsho}

Coconut oil cake came about as one such solution as a natural product with $8-12 \%$ oil or fat content. It is a by-product during production of virgin coconut oil which becomes coconut flour if pulverized or finely ground. It has more than one year of shelf life if stored at room temperature. In fact, some farmers and a veterinarian who did business with Krishi Utsho in a Northern district called Pabna were aware of the virtue of coconut oil cake in increasing milk fat content, but this knowledge was not widespread in Bangladesh. They suggested to Krishi Utsho the idea of commercializing the product to make it available to all dairy farmers in Bangladesh. A Krishi Utsho sale staff brought the idea to the attention of Krishi Utsho's leadership in one of their monthly meeting. Krishi Utsho investigated the product and found that there is indeed a potential market for such product given the demand from BOP farmers to increase their milk fat content to fetch a better market price. Krishi Utsho decided to do a pilot test of the product with few dairy farmers along with a laboratory test. The result was positive as the fat content of the milk produced increased by 
$3.5 \%$ in average. This represented a significant improvement as the maximum fat content of dairy in Bangladesh is $4.6 \%$. The detailed results of the test conducted by Krishi Utsho are found in Appendix 2. Krishi Utsho also conducted a study to assess the demand, which was projected to be close to 20 tons per month. It also assessed the supply of quality coconut oil cake and its cost-benefit analysis. Krishi Utsho found a leading firm who manufactures "Parachute" coconut oil in Bangladesh who was willing to supply top quality coconut oil cake to the network. Krishi Utsho further developed an additional partnership with a third party firm called Rosa Trade to procure, package, brand and distribute the product to the Krishi Utsho network through the OSS warehousing. As of end of December $2014,70 \%$ of the franchisees in the network sold the coconut oil cake as one of their fast moving products. This statement from the Director of Rosa Trade captured very well the excitement about the new product introduced by Krishi Utsho: "I found that the product helps to increase milk quality. Krishi Utsho can become symbol of quality. It will be an important symbol to the farmers. My projection is that after 2 years, I can carry about 100t/month."

The introduction of the coconut oil cake and the branded feed were two iconic products that the franchisees procured $100 \%$ from Krishi Utsho. The introduction of both products in the network contributed to increase the profile and the centrality of Krishi Utsho as hub firm. This also contributed to increase the brand trust of the network as the franchisees and BOP farmers were not used to these two quality products before the advent of Krishi Utsho. The process followed by Krishi Utsho in introducing the coconut oil cake and to some extent the branded feed demonstrated the openness from Krishi Utsho's leadership and staff to new ideas and suggestions that could create value to the entire 
network. This statement from the Managing Director of Krishi Utsho captured the value the network places on innovation: "We always welcome innovative ideas, because we have technical people as shop owners, livestock health worker and local agronomists on the ground. They always have some innovative ideas which do not always come through formal education but through their own experience. We always welcome those ideas. If we found any new idea, first of all we have to pilot those, if successful, as we are not planning to start our own manufacturing at this time, we can go to suppliers or manufacturers with that idea to make the product for us."

\section{VI.3.5 Managing knowledge mobility:}

In addition to the training, coaching and weekly animal health fair, which were carried over to the Growth and Reconfiguration stage to promote knowledge distribution and mobility in the network, Krishi Utsho instituted a quarterly meeting with all its franchisees (fully converted and the ones in conversion) to take stock of the progress of the network, conduct refresher training, and discuss any topic of interest for the franchisees. This created the space for the franchisees to get to know each other, to build a strong identity and social capital, to share experience, learning and tips among each other, to voice their concerns, and make recommendations and suggestions to the hub firm. As witnessed by one franchisee, "We discuss many different things and exchange ideas on how to carry and develop our business." Furthermore, Krishi Utsho organized monthly staff meetings to discuss progress, set targets, and plan ahead.

For the first time, Krishi Utsho organized an annual retreat for its staff in November 2014 to ensure that all the staff members were clear about the vision and mission of Krishi Utsho, how it is different from the SDVC project, and to strategize and plan. As witnessed by the 
Deputy Manager of the Network who was involved since the beginning of the network, "The retreat refreshes us to work in new manner." These various meetings created opportunities for the staff to share knowledge and information among themselves. The franchisees also maintain an informal network among themselves and with Krishi Utsho sale staff who visit them on a daily basis. Krishi Utsho listened closely to the BOP farmers who are the ultimate customers of the network. The weekly animal health fair described above is one such mechanism that the network used to receive feedback from the BOP farmers and to disseminate knowledge and information. The network also leveraged the opportunity they had through the SDVC project to collect feedback from the SDVC staff on what the BOP farmers are saying about the network. In addition, Krishi Utsho collected feedback from other players such as milk collectors and chilling plant managers who collaborated with the SDVC project.

\section{VI.3.6 Managing the long term sustainability of the network:}

To ensure the stability of the network and to stay true to its vision of becoming a self-sustained social enterprise, Kristi Utsho introduced in this Growth and Reconfiguration stage a royalty fee for its franchisees. Krishi Utsho kept the annual fee very minimal at this early stage to allow all the franchisees to be able to pay. The fee was set at about $\$ 65$ equivalent of local currency per year. The fee is subsidized as it did not reflect the full cost of the service the hub firm provided to the franchisees. Krishi Utsho educated the new batch of franchisees as well as the first generation on the rationale of the fees and set the effective date for the fee for the year 2015 . 
In addition to the royalty fee, Krishi Utsho also researched ways to get financial institutions in Bangladesh interested in the network to help address the working capital issue which concerned both franchisees and the hub firm. Many franchisees ranked the working capital as their concern number one at this stage of the development of the network. To address this issue, Krishi Utsho commissioned a number of studies on the subject and held negotiations with several financial institutions. Unfortunately, none of them were able to come up with a suitable solution. One key issue was the high interest rate, up to $20 \%$ per year with tangible collateral, charged by banks and microfinance institutions in Bangladesh. As a temporary solution, Krishi Utsho continued to negotiate supplier credit with its supplier firms to allow the franchisees to have between 30 to 60 days to pay back their inventories. But not all suppliers were amenable to this type of supplier credit. Krishi Utsho even had to deal with resistance from some supplier representatives who would prefer to control the terms of the partnerships with Krishi Utsho at the regional level instead of having Krishi Utsho operate at the national level because of their bonus system. In fact, the sale executives from the supplier firms were incentivized to deal directly with the franchisees instead of selling in bulk to Krishi Utsho.

\section{VI.3.7 Managing the stability of the network:}

An important challenge that surfaced during this stage was motivating women to become franchisees and to stay in the network. This challenge was mostly due to social and cultural norms in Bangladesh because of the traditional role assigned to women as housewives and caretakers of the household. This limits women mobility in their communities. As a result, very few women are engaged in business and in the market place. Few also have the financial means to invest in such business. Their workloads as wives are 
other constraints women faced, especially if their partners are not in agreement with them to engage in economic activities outside of the homestead. Krishi Utsho ended up spending a lot of time with interested women, intermediating with their families and providing one on one coaching. The success rate for women franchisees has, however, been very limited so far with only two female franchisees among the over forty five franchisees in the network as of December 2014.

Getting BOP farmers to demand and buy quality products also remained a challenge that the network continued to deal with at this stage. This issue was exacerbated by the reduction in milk price which prevented farmers from buying quality input given their low purchasing power. Further, the counterfeited products that the competitions continued to sell with a high resemblance to genuine products did not help farmers to make informed buying decision. All these factors constituted a serious threat to the stability of the network. To address these challenges, Krishi Utsho continued to work with its suppliers, the government and the franchisees as well as to collaborate with the SDVC Project to increase the absorptive capacity of the BOP farmers and advocate for quality standards in the agroinput business.

\section{VI.3.8 Network performance:}

Despite all the challenges, Krishi Utsho displayed strong performance during this stage of its development. The strong results came once again from the franchisees that were able to increase their sale by $85 \%$ on average compared to the previous year. The number of BOP farmers served by the network increased by $56 \%$ to over 17,000 . Moreover, the hub firm as franchisor was also able to double the commission it derived from its intermediation to help finance its operational cost. It is important to note, however, that the 
network remained highly subsidized by philanthropic money. The volume of products sold by the hub firm also increased drastically. For instance, for the feed which the hub firm introduced in September 2012 with about $500 \mathrm{Kg}$ sold, as of end of the year 2014, the hub firm was able to sell 400,000 Kg worth of branded feed. The hub firm also successfully introduced the coconut oil cake as a new branded product in late 2014 with a promising high demand from BOP farmers. The number of total franchisees grew to forty eight, out of which fifteen were fully branded in the previous Development and Launch stage; the number of suppliers to the network grew from four in the previous stage to nine in this stage; and, the staffing of the hub also grew from eight to ten fulltime dedicated staff serving the growing network. The hub firm was also successful in reducing the financial dependency of the franchisees for their branding.

The key network design, network orchestration, network performance and network imprinting characteristics of this Growth and Reconfiguration stage are summarized in Table 9. 
Table 9: Innovation Networking during the Growth and Reconfiguration Stage

\begin{tabular}{|c|c|c|c|}
\hline $\begin{array}{c}\text { Network } \\
\text { Design }\end{array}$ & Network Orchestration & Network Performance & $\begin{array}{l}\text { Network } \\
\text { Imprinting }\end{array}$ \\
\hline $\begin{array}{l}\text { Network membership: } \\
\text { - Revision of } \\
\text { franchisees' selection } \\
\text { criteria based on } \\
\text { lessons from the } \\
\text { previous stage } \\
\text { - Three additional } \\
\text { medicine companies } \\
\text { and two feed } \\
\text { companies added to the } \\
\text { network } \\
\text { - Introduction of royalty } \\
\text { fee for new batch of } \\
\text { franchisees } \\
\text { Network position: } \\
\text { - Network centrality } \\
\text { increased due to the } \\
\text { successful introduction } \\
\text { of the coconut oil cake } \\
\text { and the branded feed }\end{array}$ & $\begin{array}{l}\text { Managing knowledge } \\
\text { mobility: } \\
\text { - Training and } \\
\text { coaching of new } \\
\text { franchisees } \\
\text { - Quarterly meeting } \\
\text { between franchisees } \\
\text { and hub firm to } \\
\text { discuss progress and } \\
\text { share knowledge } \\
\text { - Informal feedback } \\
\text { between franchisees } \\
\text { and hub firm staff } \\
\text { Managing innovation } \\
\text { appropriability: } \\
\text { - Introduction coconut } \\
\text { oil cake to address the } \\
\text { low milk fat content } \\
\text { issue for BOP } \\
\text { farmers } \\
\text { Managing network } \\
\text { stability: } \\
\text { - Outsourcing of the } \\
\text { supply chain } \\
\text { management to } \\
\text { address CARE's } \\
\text { restrictive policy } \\
\text { - Recruitment of a } \\
\text { Managing Director } \\
\text { and appointment of a } \\
\text { dedicated Krishi } \\
\text { Utshotwoam teaisees in the } \\
\text { challenge given social } \\
\text { norms } \\
\text { affordable working } \\
\text { capital with financial } \\
\text { institutions } \\
\text { - }\end{array}$ & $\begin{array}{l}\text { - The franchisees } \\
\text { increased their sale by } \\
85 \% \text { on average } \\
\text { - The hub firm doubled } \\
\text { its commission as } \\
\text { contribution to its } \\
\text { operational cost } \\
\text { - The network increased } \\
\text { its reach by } 56 \% \text { to a } \\
\text { total of } 17,000 \text { BOP } \\
\text { farmers } \\
\text { - Krishi Utsho added an } \\
\text { additional } 33 \text { in } \\
\text { conversion } \\
\text { franchisees, bringing } \\
\text { the total number to } 48 \\
\text { - } 5 \text { new firms joined the } \\
\text { network as suppliers } \\
\text { and sub-contractors }\end{array}$ & $\begin{array}{l}\text { Network persistence: } \\
\text { - Krishi Utsho } \\
\text { continued to struggle } \\
\text { changing the negative } \\
\text { habit of franchisees } \\
\text { carrying and selling } \\
\text { low quality products } \\
\text { - Krishi Utsho } \\
\text { continued to struggle } \\
\text { introducing a } \\
\text { professional business } \\
\text { management } \\
\text { practices to } \\
\text { franchisees } \\
\text { - CARE HR was not } \\
\text { initially flexible to } \\
\text { accommodate the } \\
\text { salary of the Hub } \\
\text { Manager }\end{array}$ \\
\hline
\end{tabular}

\section{VI.4 2015 and onward: Consolidation and Expansion}

The first quarter of 2015 was a challenging start of the year that threatened the stability of the Krishi Utsho network with a political turmoil between the two main political 
parties in Bangladesh with nationwide protests and traffic blockades and many violent and fatal attacks on the public. The country and its economy were paralyzed for the most part of the first quarter of the year. According to one leading source of news, the Dhaka Tribune (www.dhakatribune.com), the World Bank estimated that the political unrest cost the country up to $\$ 2.20$ billion. Many lives were also lost. Krishi Utsho's business was impacted as it was the case in 2013 due to the road blockade and the difficulties of moving goods around. "This was horrible for us. Farmers could not sell their production, they could not buy input. It was a huge loss, especially for perishable products such as dairy," said the Deputy Manager of the network. However, based on lessons learnt from the similar situation in 2013, the Krishi Utsho team managed to maintain minimum operations, moving goods to franchisees from willing suppliers during night times and over the weekend when situations allowed. Krishi Utsho also leveraged the technology capabilities of its third party supply chain management firm to introduce an IT enabled mobile phone payment system. Further, Krishi Utsho innovated by organizing franchisees into group to promote their products at a single point in the community where BOP farmers could easily gather and where franchisees could carry their products to allow BOP farmers to make their purchase. These innovative actions taken by the hub firm contributed to increase its centrality and the trust from franchisees and BOP farmers as a credible network designer and orchestrator who committed to stay true to its mission and vision despite adverse and difficult situations.

\section{VI.4.1 Developing a new business plan for the network:}

Although paralyzed by the political unrest during the first quarter of 2015, Krishi Utsho used the slowdown of the business to consolidate its learning and achievements 
through development of a business plan for continued expansion of the network to create value for all the stakeholders involved. The three year experience through the previous stages of the network and the "learning by doing" approach used by Krishi Utsho helped to refine its understanding of the network and to confidently make realistic assumptions and financial projections about the future of the network. To develop the business plan, Krishi Utsho conducted a number of studies including a market assessment and detailed discussions with franchisees, suppliers, competitions and other key stakeholders of the network. The business plan process allowed the network to clarify and re-affirm its mission, vision and value proposition. Its mission statement found in its business plan reads as follows: "our mission is to be the preferred shopping destination for agro input products and services for all smallholder farmers in Bangladesh. We will uphold this mission by selling quality agro inputs in the market and providing excellent service to customers. We will be a leader in the agro input industry by serving marginalized populations in rural Bangladesh. Krishi Utsho's aim is to increase the yield and quality of farmer livestock outputs and ultimately improve the economic livelihoods of rural farming households. Krishi Utsho will advocate for women empowerment by selecting women franchisees to join the network." Our interview with the franchisees and Krishi Utsho's staff demonstrated a high level of understanding of this mission. The business plan also afforded the opportunity to clarify the path of the network to become an independent spin-off social enterprise under CARE Enterprise Inc. Further, it made assumptions about its financial viability with a break even anticipated in the fiscal year 2019. As a result, Krishi Utsho projects to have 270 franchisees in the network by 2022, to expand geographically and start offering a range of additional product such as poultry, horticulture and fishery. Ultimately, 
the business plan constituted a road map for the network. In addition, it allowed the hub firm to estimate the resources it needed to achieve its ambitious goals and it represented an important negotiation, marketing and fundraising tool for the network.

\section{VI.4.2 Understanding the impact on BOP farmers:}

The Consolidation and Expansion stage was also marked by a detailed assessment Krishi Utsho conducted to understand the social and economic impact of the network on BOP farmers as part of its customer base. The impact assessment was designed and implemented in house and covered 400 BOP farmers in various geographies in Northern Bangladesh, namely Bogra, Sirajganj, Ranpur and Pabna. The survey was designed to compare the before and after impact on a range of socio-economic indicators. The major indicators on which data were collected included among others cost of input, time savings, income of the BOP household, food security and women empowerment status. Overall the result was very positive with marked impact on cost and time savings for BOP farmers. On average, the introduction and orchestration of the network decreased the time and cost spent by BOP farmers to access agro-input, notably, feed, medicine and vitamins by $50 \%$. The frequency of visit to franchisees by BOP farmers increased from 2.8 to 3.7 times per week as a result of the closer proximity. The survey also revealed a $31 \%$ increase in the household income of the BOP farmers, from an average of an equivalent of $\$ 175$ per month to $\$ 230$. The food security status of the BOP farmers assessed through their expenditure on food items such as wheat, rice, fish, meat and vegetable increased between 10 and $15 \%$. The empowerment status of women, specifically as related to women's influence on household decision making over economic matters increased steadily from $45 \%$ before to $85 \%$ after the introduction of Krishi Utsho (the SDVC project also contributed significantly to these last 
two indicators as Krishi Utsho was operating in the same geographies). These positive impacts demonstrate how effective the network is in co-creating tangible value for BOP farmers in Bangladesh. Appendix 3 has further impact data from the survey conducted by the Krishi Utsho team

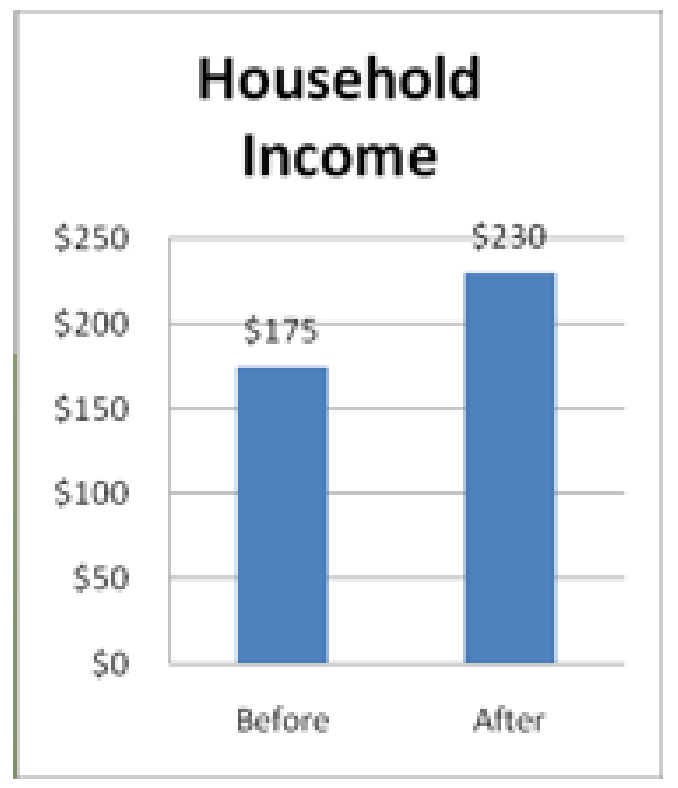

Figure 10: Household Income before and after Krishi Utsho

Table 10: Availability of inputs before and after Krishi Utsho

\begin{tabular}{|c|r|r|r|r|r|r|}
\hline \multirow{2}{*}{ Indicator } & \multicolumn{2}{|c|}{ Availability of Inputs } & \multicolumn{2}{c|}{ Medicine } & \multicolumn{2}{c|}{ Vitamin } \\
\cline { 2 - 7 } & Before & \multicolumn{1}{|c|}{ After } & Before & \multicolumn{1}{c|}{ After } & Before & \multicolumn{1}{c|}{ After } \\
\hline Distance Travelled (KM) & 2.28 & 0.98 & 2.59 & 1.67 & 2.65 & 1.79 \\
\hline Time 5pent for Travel (Min.) & 28.21 & 12.12 & 28.07 & 15.55 & 27.39 & 16.89 \\
\hline Cost of Travel (BDT) & 66.36 & 5.69 & 20.25 & 8.27 & 17.97 & 9.10 \\
\hline
\end{tabular}




\section{VI.4.3 Recruiting new members to the network:}

Staying true to the roadmap developed early in the year, Krishi Utsho continued to recruit new candidate franchisees to expand the network. This time, Krishi Utsho also started to expand the network in the southern part of the country. To go south, Krishi Utsho partnered with a consortium of organizations under the leadership of a local renowned development organization called DAM. CARE is also part of the consortium that is implementing an agriculture development project with funding from the US Government. The aim of the agriculture project is aligned with the mission pursued by Krishi Utsho which is to offer BOP farmers a timely access to a range of quality and affordable agriculture input and services to boost agriculture productivity, achieve food and nutrition security and reduce poverty. This partnership offered a "win-win" opportunity for Krishi Utsho to extend its network to the Southern part of the country and to start a small pilot with five candidate franchisees selected to go through the recruitment process described in Figure 6. As a niche product for the South, Krishi Utsho selected animal feeding concentrate given the prominence of livestock fattening and commercialization in that part of the country. Krishi Utsho is also in discussion with a number of companies who may be interested in joining the network in the south. The negotiation was in its early days by the time we concluded our data collection. At the same time, Krishi Utsho continued to recruit other candidate franchisees in the northern region of the country where it has its foundation. The informal LHW association facilitated by the SDVC project continued to be a good platform for information sharing and for identifying potential franchisees. As of the end of December 2015, Krishi Utsho had 112 branded and in-conversion franchisees in the network. This number includes fifteen additional fully branded franchisees that Krishi 
Utsho inaugurated in June 2015. The inauguration was an opportunity to invite the surrounding community members as well as the Head of the Livestock Department from the District Government Offices to promote the network. This made the total number of branded franchisees to twenty-eight because two branded franchisees in the earlier stage dropped out from the network. The main reasons for the attrition were that the two franchisees were no longer able to meet the standard set up by the hub firm and went out of business. Eighteen other candidate franchisees are identified to be branded in early 2016.

\section{VI.4.4 Introducing new line of products:}

On the products and services front, Krishi Utsho conducted a market demand assessment to understand other products BOP farmers are interested in and could buy. Based on the assessment and several feedbacks received from the franchisees themselves, Krishi Utsho decided to introduce aquaculture products into the network. Hence, Krishi Utsho selected four different products for further laboratory and field tests. Three suppliers of aquaculture and Tamim Agro, an existing supplier firm in the network, are the manufacturers of the products under testing. The results of the test are still pending. Poultry products are next in line, but Krishi Utsho prefers taking a stepwise approach in introducing new products in the network to minimize risks.

\section{VI.4.5 Continuous improvement of the supply chain:}

Reducing waste and making the network efficient continued to be the focus of Krishi Utsho in this stage. In addition, having a better handle on the supply chain management instead of relying heavily on a third party firm was a continuous concern for Krishi Utsho given how vital this aspect is for the stability of network. To that effect, Krishi Utsho held 
several brainstorming and discussion meetings with OSS, the third party supply chain manager, the franchisees, and the supplier firm members of the network. As a result, Krishi Utsho finally made the decision to do away with expensive warehouses and to experiment with a stack point model. The stack points are designed to be strategically located in close proximity of a cluster of franchisees in order to minimize logistics cost and increase speed in moving inventories. Stack points are smaller version of warehouses, are easier to manage, and have a much lower operation cost. As of December 2015, five stack points are established with only one warehouse maintained. The three other warehouses were closed. Krishi Utsho also negotiated with the suppliers to deliver smaller quantities directly to the stack points. The Feed firm Tamim Agro was particularly supportive of the new modality and is working with Krishi Utsho to promote the new stack point model. OSS still played a role in the supply chain management, but this time its role was reconfigured and somewhat reduced. OSS now handles the transactions with the suppliers and maintains the inventory of the stack points. OSS also continued to handle all the banking transactions associated with the new modality as well as the leasing of the stack points given the fact that Krishi Utsho is still a project within CARE and do not yet have the legal status to operate its own bank account and other administrative tasks given CARE's onerous compliance standards. However, Krishi Utsho decided to play a larger role and is now in charge of products delivery to the franchisees' outlets and payment collection through its sales executives. This new modality has proven quite effective with an expected reduction of $40 \%$ of the supply chain cost. Krishi Utsho also continued to leverage the IT capability of OSS for the supply chain management of the network. 


\section{VI.4.6 Organizing the first closing event:}

A significant activity organized by Krishi Utsho in June 2015 was a "closing event" to mark the end of its fiscal year. This was the first time Krishi Utsho organized such an event as an opportunity to recognize, motivate and reward best performing franchisees in the network. Krishi Utsho also used the same opportunity to dialogue with the franchisees about the vision of the network, the plan for the new fiscal year, the quality standards and its expansion plan and to promote learning amongst the franchisees. The event also afforded the opportunity to the hub firm to collect any remaining payment from the franchisees. The event was organized in each of the four districts currently covered by the network in the northern part of the country, which are Bogra, Sirajganj, Rangpur and Pabna. The hub firm rewarded two categories of performance. In total eight franchisees were selected and rewarded, four in the category of bestseller with the highest revenue and customer service and the other four in the category of best franchisees with the highest financial transactions and payment record with the hub firm. The closing event was very successful and generated a high level of enthusiasm and awareness amongst the franchisees. It also contributed to increase the position of the hub firm in relation to the franchisees. The Managing Director of the network was very pleased with the outcome and promised to repeat it every year and to open it to other stakeholders of the network, specifically the supplier firms.

\section{VI.4.7 Securing additional funding for the network:}

The new business plan developed by the network helped crystalize the financial resources the network needed to expand and for Krishi Utsho as a hub firm and franchisor to reach breakeven and spin off as an independent social enterprise. To mobilize the 
financial resources, Krishi Utsho prioritized receiving additional grants to build up its equity base before mobilizing external commercial funding such as equity and debt. In that regard, Krishi Utsho developed and submitted a number of proposals to various philanthropic organizations. One lead donor that Krishi Utsho pursued aggressively in this stage was the Embassy of the Kingdom of Netherland in Bangladesh who is interested in the agriculture sector development for BOP farmers to achieve food and nutrition security and end poverty. Hence, Krishi Utsho visited with the Embassy on many occasions to present the network and its new business plan. As a result of the sustained cultivation effort, Krishi Utsho was invited by the Embassy to submit a proposal for grant funding in May 2015. After several months of review and negotiations, Krishi Utsho finally got an official letter from the Embassy on October 17, 2015 notifying the approval by the Ambassador of a grant of $\$ 1.3$ million to the network. This was exciting news for Krishi Utsho and CARE as this new grant, the largest in Krishi Utsho's history, was exactly what the network needed to expand and execute its newly developed business plan. In the words of the Manager of the Network, "this new grant will help us execute our business plan and become a fully fledge social enterprise. We are very grateful to the Embassy of Netherland."

\section{VI.4.8 Network performance:}

This last stage in the life of the Krishi Utsho has proven another success with a strong network performance. The new financial resource mobilized from the Embassy of Netherland in Bangladesh gave a strong momentum to the Krishi Utsho team to gain the confidence to continue to design and orchestrate the network to co-create value for all involved. 


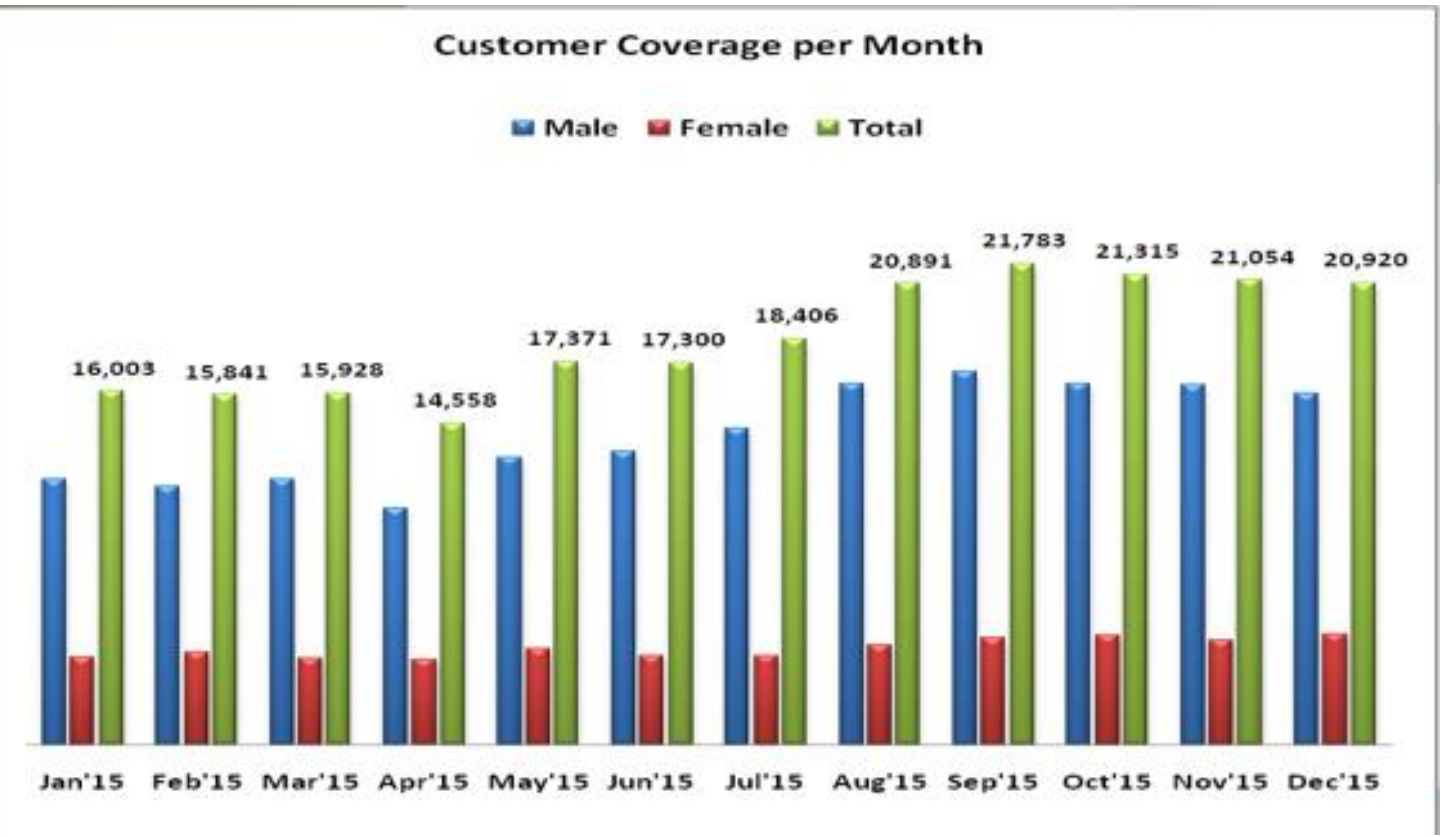

Figure 11: Customer coverage per month

The strong positive result from the impact assessment was another key ingredient to demonstrate how value is being created and captured by BOP farmers who are the ultimate target of the network. As in the previous stages, the franchisees continued to demonstrate a strong financial performance. For this stage, the franchisees increased their annual sale by $34 \%$. The hub firm also increased its commission by 2.1 times allowing it to cover part of its operation costs. Over 20,000 customers were served by end of December 2015 , which is an increase of $17 \%$ compared to the previous stage. The network also realized significant cost reduction in its supply chain management of up to $40 \%$. Forty six candidate franchisees were added to the network bringing the total number to hundred and ten, out of which twenty eight were fully branded. Two franchisees unfortunately dropped out in this stage, bringing the total number of drop out to four. The main reason for the drop out is franchisee behavior contrary to network standards. One was involved in politics 
and abandoned the management of the shop while the second one was involved in gambling, using the financial resources of its business.

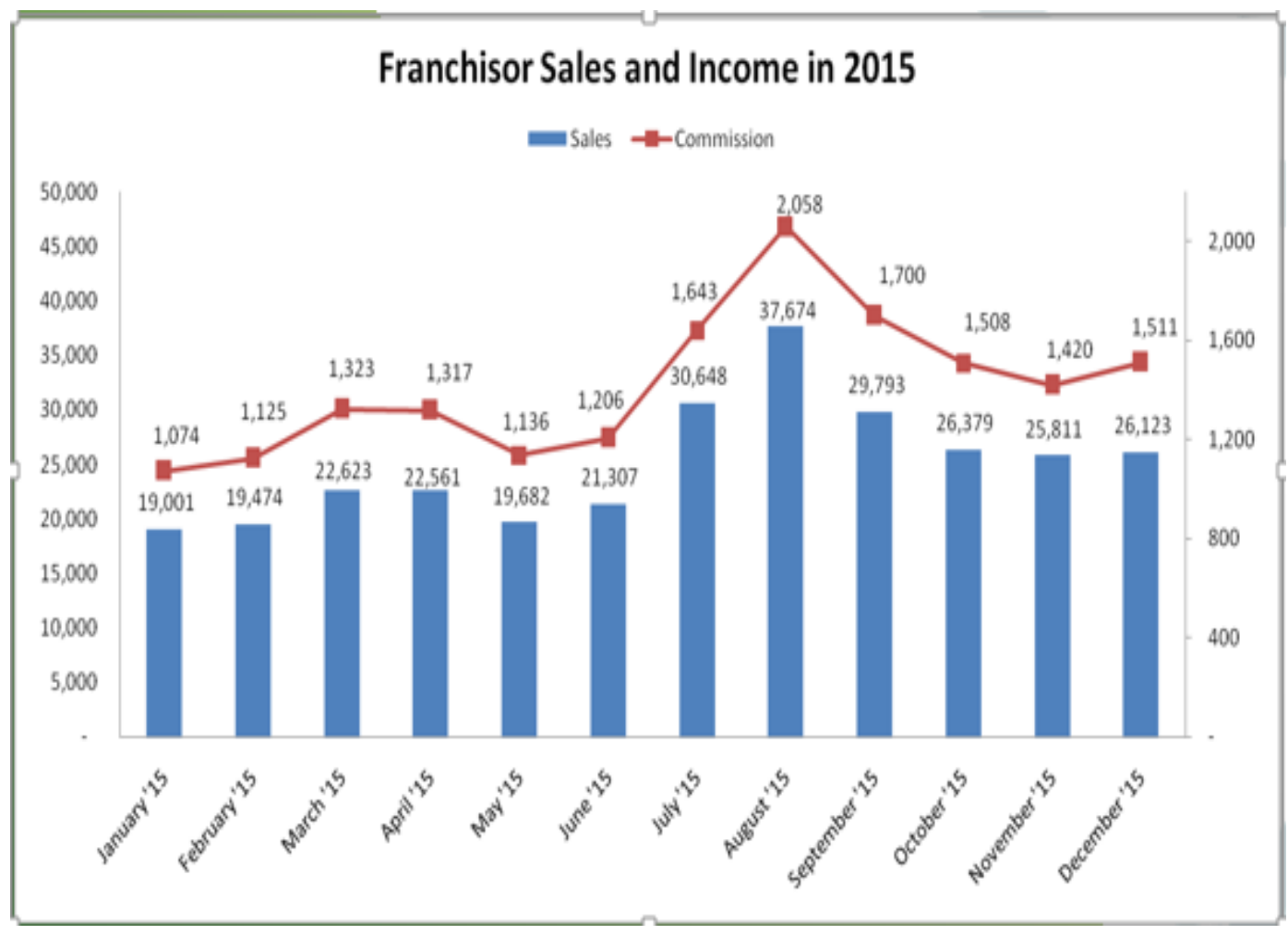

Figure 12: Franchisor Sales and Income in 2015

\section{VI.4.9 Managing the network stability and sustainability:}

Despite the successful year 2015, Krishi Utsho continued to face important challenges which threaten the stability of the network and its ability to create sustained innovation outcome for its stakeholders. The network negative imprinting described above, such as the poor adherence to quality and management standards by the franchisees and their lack of adequate working capital, are specific examples. The continued competition in the market, especially from low quality medicines firms dumping the market and luring franchisees with cheap quality product reinforced this behavior. The hub firm was spending the bulk of its time to address these challenges through continuous refresher training, 
coaching and knowledge exchange among suppliers and franchisees. The hub firm also used the opportunity of the organization of some franchisees in informal network such as the LHW association to identify champion franchisees to exert peer pressure on other lagging franchisees and to continuously communicate about the standards of the network. Demand creation for quality products and services amongst BOP farmers was another challenge the hub firm and the members of the network addressed through the weekly animal health fair and other customer education such as marketing campaigns.

Another important challenge was the lack of understanding of the mission and the end goal of Krishi Utsho by the majority of the suppliers. This confusion came from the fact that Krishi Utsho did not yet have a high brand visibility with many of the suppliers, and the later still associated the network with a typical time-bound development project of CARE. Many sales managers and representatives interviewed at the regional level cannot articulate Krishi Utsho's mission, vision, and its long-term plan to become an independent financially viable and impactful social enterprise contrary to the franchisees. With the exception of the feed firms, the medicine firms have a well-developed distribution network in Bangladesh and they did not yet comprehend the full value proposition of Krishi Utsho. They are also part of a number of professional associations in the country such as the Animal Health Association and the World Poultry Science Association at the national and regional levels. As a result, although they do business with the network, their sense of belonging to the Krishi Utsho network is not as strong as the franchisees. Hence, they treat Krishi Utsho as any other wholesale buyer. This also affects the financial negotiation between Krishi Utsho and the medicine companies and some of the resistance we described above. The weak rule of law in Bangladesh and the fact that there was no contract signed 
between Krishi Utsho as franchisor and the franchisees are other challenges that could affect the stability of the network. In the word of a senior staff of the network, "one threat that I see is if the franchisees become well organized in their association, they can link up directly with the companies we work with today. This could create a direct conflict." This has not manifested yet, but a risk worth pointing out.

The key network design, network orchestration, network performance and network imprinting characteristics of this fourth episode are summarized in Table 10. 
Table 11: Innovation Networking during the Consolidation and Expansion Stage

\begin{tabular}{|c|c|c|c|}
\hline $\begin{array}{c}\text { Network } \\
\text { Design }\end{array}$ & Network Orchestration & Network Performance & $\begin{array}{c}\text { Network } \\
\text { Imprinting }\end{array}$ \\
\hline 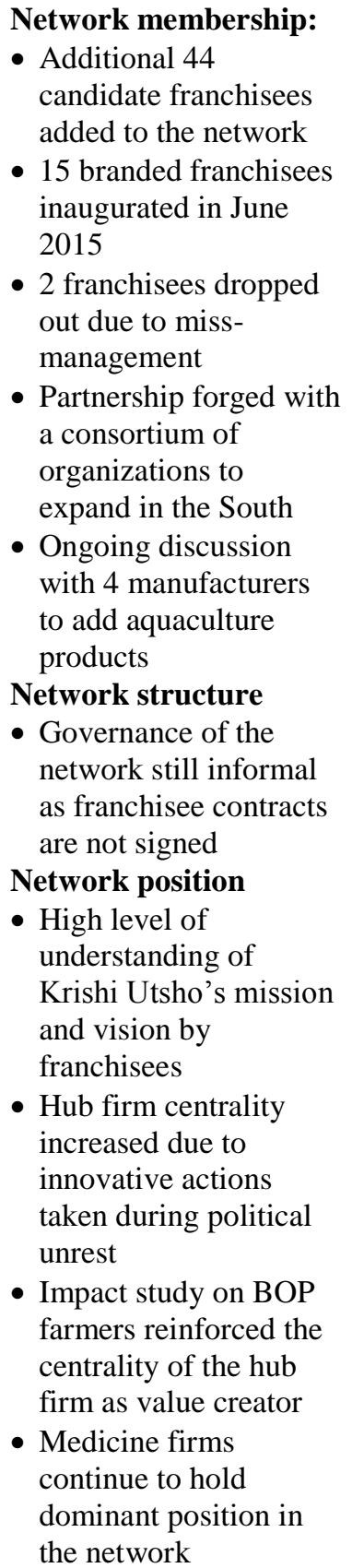 & 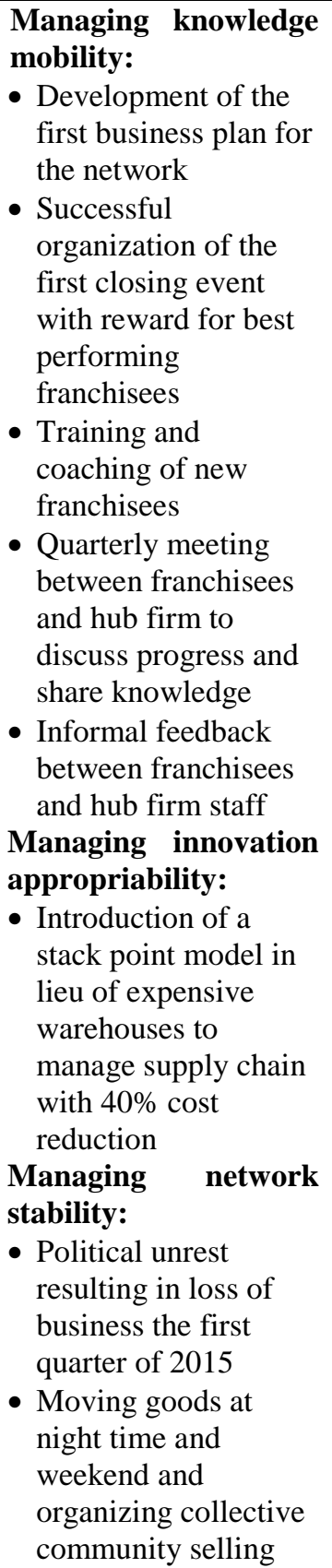 & $\begin{array}{l}\text { - The franchisees } \\
\text { increased sale by } 34 \% \\
\text { on average } \\
\text { - The hub firm multiply } \\
\text { its commission by } 2.1 \\
\text { to contribute to its } \\
\text { operational cost } \\
\text { - The network increased } \\
\text { its reach by } 17 \% \text { to a } \\
\text { total of } 20,000 \text { BOP } \\
\text { farmers } \\
\text { - Reduction of } \\
\text { operation cost of the } \\
\text { supply chain } \\
\text { management by } 40 \% \\
\text { - Impressive impact on } \\
\text { BOP farmers } \\
\text { demonstrating how the } \\
\text { network is co-creating } \\
\text { value for its primary } \\
\text { stakeholders }\end{array}$ & $\begin{array}{l}\text { Network persistence: } \\
\text { - Krishi Utsho } \\
\text { continued to struggle } \\
\text { to change the bad } \\
\text { habit of the } \\
\text { franchisees in } \\
\text { carrying and selling } \\
\text { low quality products } \\
\text { - Krishi Utsho } \\
\text { continue to struggle } \\
\text { to introduce } \\
\text { professional business } \\
\text { management } \\
\text { practices to } \\
\text { franchisees } \\
\text { - Krishi Utsho } \\
\text { leveraged the } \\
\text { informal association } \\
\text { of the franchisees to } \\
\text { exert peer pressure } \\
\text { and communicate } \\
\text { quality standards } \\
\text { - Supplier firms } \\
\text { organized in other } \\
\text { network and have a } \\
\text { lower sense of } \\
\text { belonging to Krishi } \\
\text { Utsho } \\
\text { - CARE overshadowed } \\
\text { Krishi Utsho as an } \\
\text { aspiring independent } \\
\text { social enterprise. }\end{array}$ \\
\hline
\end{tabular}




\section{DISCUSSION AND CONTRIBUTIONS}

Drawing upon Orchestration of Innovation Network (Dhanaraj \& Parkhe, 2006) and Network Imprinting (Marquis and Tilcsik, 2013) as theoretical framework and based on a longitudinal case study that covered over five years of rich data, this research has explored how CARE designed and orchestrated a microfranchise network to facilitate the provision of timely access to quality and affordable agriculture input and services to BOP farmers in Bangladesh. We have demonstrated how the microfranchise network evolved over time through four stages and how the design and orchestration played out. We have also highlighted the imprinting of each network member and other key stakeholders and how these path dependencies altered the way the network was designed and orchestrated to achieve outcomes. In the following, we articulate and discuss the consequential contributions to theory and practice.

\section{VII.1 Contributions to Theory}

Microfranchising is increasingly gaining in popularity as an effective business model in the BOP context. The microfranchise literature has, however, dealt mostly with the potential benefits of microfranchising (Fairbourne, 2007; Gibson, 2007; Magleby, 2007). Economic growth and efficiency as means of achieving poverty alleviation goals (Kistruck, Webb, Sutter, \& Ireland, 2011) have been studied extensively in the literature. The reduced risk from buying into a "proven business system" (Fairbourne, 2007), and the benefits of belonging to part of a "democratic network" (Magleby, 2007, p. 46) are other issues highlighted in the literature. Kistruck et al. (2011) also conducted studies contrasting the traditional franchising system to microfranchising in the BOP context looking at three 
key performance drivers that research suggests are associated with franchising: overcoming agency concerns, reducing resource scarcity, and leveraging brands and standardizing operations.

The literature is, however, silent on how microfranchise models emerge and materialize through design and orchestration of innovation networks aimed at co-creating value with BOP entrepreneurs. Furthermore, such microfranchise-based innovation networks engage BOP entrepreneurs and firms with past and current ties and practices into a new network. Rather than dealing with this important issue separately, BOP theory could benefit from bringing together the imprinting and the orchestration of innovation network perspectives into an integrated theoretical and practical understanding. Hence, based on our empirical findings and extant literature, we suggest a number of propositions that the BOP, microfranchise and innovation network literatures may use to improve the processes by which microfranchise-based innovation networks are designed and orchestrated to realize the win-win potential in emergent BOP markets. Following, we develop two propositions to contribute to the BOP and microfranchise literature and an integrated framework to contribute to the network innovation literature in general.

\section{The importance of decentralization and management of innovation and knowledge in microfranchise network:}

Traditional franchising typically involves a tight coupling of franchisees that subscribe to a certain business format and are committed to follow strict guidelines and standards. Creating a unified network with rather clear identity, it is a recipe for scaling up a proven business model to create economic growth and meet customers' expectations. However, the achieved degree of unity and standardization may cause problems, since it 
suppresses variety and, thus, innovation (Pratt \& Foreman, 2000). In these traditional arrangements, continuous innovation and knowledge are driven from the top (the franchisor) with little room for the franchisees to contribute knowledge and innovate themselves. A study conducted on McDonald's network in Germany found that due to the sustained and tight strategic leadership of the network by the headquarters and its regional representatives, the identity of the McDonald's network seems to interpenetrate the identities of the franchisees and their outlets to an extent that leaves the outlets with requisite identity adoption rather than opportunities for identity creation (Rometsch \& Sydow, 2003).

In contrast, we argue that the studied microfranchise network, which emerged on the premise of achieving social goal at scale while creating a scalable platform for small and independent entrepreneurs to expand their business, had room to co-create innovation and knowledge to achieve intended results. This is particularly important given the difficult social issue many microfranchise networks aim to solve within a fragmented and weak institutional context (Kistruck, 2011). As such, associating the BOP population themselves and using the knowledge and creativity of small and micro entrepreneurs in the BOP market and all the other actors involved have considerable potential for knowledge and innovation co-creation to achieve success (Simanis \& Hart, 2008). We therefore posit that microfranchise networks operating in difficult environment and with their main goal of creating social value would more benefit from decentralizing and adapting knowledge and innovation in contrast with traditional franchise networks operating in stable and developed environment and with the main motive of maximizing shareholder values. 
The burgeoning microfranchise literature is, however, silent on the knowledge and innovation co-creation and the orchestration role that the hub firm plays to achieve the objective of the network. As stated above, we argue that to be successful, decentralizing, adapting and managing knowledge and innovation are important part of microfranchise network. Microfranchising in itself represents an innovation which is a departure from traditional enterprise development in the BOP market which considers every single small and informal business owner as entrepreneurs. Microfranchise has offered a business framework to organize those micro-entrepreneurs and to enable them to access organized supply chain and capacity which they otherwise struggle to access given many institutional voids in developing markets (Fairbourne, 2007). Hence, our study suggests that the innovation network literature is a fertile ground to leverage new insights into microfranchise literature. Orchestration of innovation framework developed by Dhanaraj and Parkhe (2006) and many subsequent empirical studies conducted by scholars such as Ojasalo (2008), Busquets (2010), Nambisan and Sawusing (2011), and Leven et al. (2014) have demonstrated the value addition that is derived from managing innovation appropriability and knowledge mobility as part of the network orchestration function of the hub firm.

Our case study revealed how BOP farmers, the microfranchisees and the suppliers were given the space by the hub firm within the network to make suggestions and innovate. As an example, our empirical results demonstrated that the coconut oil cake, although used in some part of Bangladesh, was not a commercial product. Krishi Utsho as a hub firm demonstrated its openness to the idea and suggestions made by the microfranchisees and the BOP farmers and took on itself to further investigate the viability and efficacy of the 
product to contribute to solve an important milk quality issue BOP farmers were confronted with. Our analysis demonstrates how the hub firm valued the creativity and suggestions coming from the network members and how it further investigated the potential of the new product and launched it in the market. As a result of this openness to innovation and feedback from the network members, the coconut oil cake is now becoming a top performer product for Krishi Utsho.

Ensuring knowledge mobility between various network members, in our study between supplier firms and microfranchisees on technical topic such as animal health product's prescription, disease detection and technical advice to customers among others, proved to be a useful and cost effective way to manage knowledge mobility towards achieving the intended quality standard. The hub firm did not have to develop all the expertise in house. It effectively leveraged the expertise and capabilities of other network participants, in this case the suppliers, to educate the microfranchisees. Our evidence also revealed that in addition to leveraging the supplier firms, the hub firm worked with the public sector animal health department to have them train the microfranchisees and BOP farmers on animal health issues. The hub firm also decentralized the knowledge sharing and assured knowledge mobility through the weekly health fair it organized for the BOP farmers and in which both the government department and the private supplier firms participated. The BOP population who is customer of the network was empowered to contribute to knowledge and innovation to achieve the goal of the network. However, the hub firm played a strong coordination role to ensure that knowledge generated and shared are adding value to the network instead of disengaging itself from this role. This was demonstrated by the fact that the hub firm used the weekly health fair to listen to the 
concern of BOP farmers and collected their suggestions on how to continuously improve the network. The three way innovative payment system that the hub firm established between the microfranchisees, the milk collectors and the BOP farmers is a good illustration of this. Engaging BOP population in designing and applying strategies to solve BOP issues while creating value for business is in line with the mutual value creation in the BOP literature which London et al. (2010) and many scholars have advocated. Furthermore, our findings are in line with the adaptation to knowledge templates in BOP markets and the role of social interaction between BOP entrepreneurs and technical experts who understand the "why behind each practice", in this case the hub firm itself but also the supplier firms and the government veterinarian offices, to result in improved performance (Sutter et al., 2014).

Hence, we argue that microfranchise networks have a lot to learn from innovation networks theory. The hub firm, the microfranchisor, has a strong role to play to manage knowledge mobility and innovation appropriability within the network (Dhanaraj and Parkhe). It has to create the appropriate environment to unleash the potential of the network members, including the BOP population, to generate innovation and knowledge, to collaborate and form multiplex relationships in order to co-create value. Thus, a "table with four legs" analogy could be used to illustrate the important role we see for each category of the network actors, in this case the hub firm (1), the microfranchisees (2), the suppliers and any other key actors (3) and the customer themselves such as BOP farmers (4) to be actively involved and incentivized to create knowledge and innovation and to share them among the network members when appropriate. However, given the difficult BOP context characterized by weak human, social and financial capitals and institutional void, 
knowledge and innovation can leak easily, and as demonstrated by Sutter et al. (2014), social interaction among BOP entrepreneurs themselves without an intermediation from an expert broker could be presumptive. It is therefore primordial for the hub firm to continuously educate network members, forge a fruitful relationship, set a robust rule of engagement and manage knowledge creation and mobility as well as innovation appropriability effectively to achieve the financial and social impact goals of the network. Hence, we posit that:

Proposition 1: Microfranchise-based innovation networks will more likely enable co-creation of value when the hub firm decentralizes and orchestrates knowledge and innovation management and enables broad participation.

The importance of identifying and managing imprinting in microfranchise-base innovation networks:

While the origins of an organizational identity lie in the decisions and actions taken at the time of creation, the identity forms and solidifies over time in a somewhat pathdependent process (Albert \& Whetten 1985). As defined by Marquis and Tilcsik (2013), members of networks and associated stakeholders all develop characteristics that reflect prominent features of their formative environment which persist despite significant environment changes in subsequent periods. Subsequent research suggests that imprinting may have long lasting effects upon the strategies, strategic choices, and operating practices of firms (Bamford, Dean, \& McDougall, 2000; Kriauciunas \& Kale, 2006). As such, organizational imprints establish powerful behavior guidelines that affect organizational choices and performance. If imprints are critical to firm behaviors and choices, then achieving competitive advantage and above normal returns may be dependent on organizational imprints (Kriauciunas \& Shinkle, 2008). 
Hence, it is extremely important to understand the imprints of each prospective and current member, in this case microfranchisees, the microfranchisor itself and any other stakeholders associated with the network such as suppliers, financial services providers and BOP population. In the case of the microfranchise-base innovation network, Krishi Utsho, imprinting affected the behavior, culture, business model or ways of doing business, membership in formal and informal network, perception and aspirations, motivation and incentive systems of the network members. We revealed that some imprints were positive while others were negative. Strategies should aim at managing both and managers should design and orchestrate microfranchise innovation networks accordingly. The positive imprinting is an asset to leverage to achieve the goal of the network while the negative one should be managed carefully in order to reduce damaging impact on the network's outcomes.

Our empirical evidence revealed a number of examples to illustrate both negative and positive imprints of the network members. For instance, selling poor quality products to BOP farmers was one negative imprint of the microfranchisees joining the Krishi Utsho network. Lack of trust between BOP farmers and the microfranchisees was another negative imprinting revealed in our empirical study. The microfranchisor did put a lot of effort and investment to reduce this imprinting and forge new paths for the microfranchisees to adopt quality norms and use the best in class customer services strategies. On the other hand, the hub firm leveraged the informal network that already existed between the franchisees as they were part of the livestock health workers association to drive home its value proposition and recruit prospective microfranchisees. Krishi Utsho also used peer pressure to discourage malpractice in the network. Both are 
good example of how the hub firm leveraged the positive imprinting of some of the network members. Another example of how the hub firm leveraged the positive imprinting was by organizing weekly animal health fairs to educate customers and bring them closer to the microfranchisees to build trust.

Understanding the imprints and categorizing them will help to develop strategies and tactics to manage them. It will also contribute to decision making for a more effective design and orchestration of the network. For instance, once Krishi Utsho had a better understanding of the imprinting of the microfranchisees, it refined a set of selection criteria to recruit the new cohort of prospective microfranchisees into the network in the Growth and Reconfiguration stage. Our empirical evidence also revealed that once the hub firm had better understood that the animal health supplier firms did not have the vested interest to change their business model given their well-developed distribution channel, it started to diversify its supplier firms with new ones willing to change and adapt their business model to Krishi Utsho.

We also argue that imprinting affects network structure and network position in the design process and should be carefully managed. Our evidence demonstrated that the imprinting of the franchisees and the BOP context which is characterized by weaker formal institutional environments and weak rule of law (de Soto, 2000) makes the governance of the network unpredictable and informal. Although Krishi Utsho drafted a franchise contract, it has not signed it yet because of the inability to enforce contract in rural Bangladesh. Another reason was the fact that many microfranchisees were not used to signing and respecting formal contract. Krishi Utsho is therefore investing its limited resources to educate the microfranchisees to understand the importance of signing and 
respecting contract before signing it with them. As a result, Krishi Utsho had to anticipate any risks the weak structuring of the network may create and needed to be pro-active in managing it. One example from our evidence of this is the fact that a microfranchisee revealed his intention to go to the same supplier firms and buy in bulk and sell to other microfranchisees in the network. This thought impedes on the essence of what Krishi Utsho as a hub firm and microfranchisor is doing for the network.

In addition to network structure, imprinting affects the network position. Our evidence revealed many instances of this phenomena. One example was the lack of understanding of the mission and the end goal of Krishi Utsho by the majority of the supplier firms. This confusion came from the fact that Krishi Utsho did not yet have a high brand visibility with many of the supplier firms, and the later still associated the network with a typical time-bound development project of CARE. As a result, many decisions and actions from the supplier firms, especially the animal medicine firms undermine the positioning of Krishi Utsho as the hub firm. A concrete illustration is that sale managers from the supplier firms at the regional level competed with Krishi Utsho and positioned themselves directly with the microfranchisees to be able to derive higher sale in order to capture higher bonus for themselves. This highly undermined the position of Krishi Utsho in the network.

Drawing on our case analysis and extant literature, Table 11 highlights some imprinting in BOP context and some exemplar strategies to manage them, especially in the agriculture sector, which designers of microfranchise network should be aware of. In conclusion we posit that: 
Proposition 2: Microfranchise-based innovation networks will more likely enable co-creation of value if the hub firm considers and appropriately manages the imprinting of participants during the network design and orchestration

\section{Table 12: Imprinting and exemplar strategies}

\begin{tabular}{|c|c|c|c|}
\hline Stakeholders & Positive Imprints & Negative Imprints & Management strategies for hub firm \\
\hline Microfranchisees & $\begin{array}{l}\text { Membership in } \\
\text { informal network }\end{array}$ & $\begin{array}{l}\text { Poor adherence to } \\
\text { quality standards }\end{array}$ & $\begin{array}{l}\text { Leverage informal network } \\
\text { membership to recruit members } \\
\text { into the microfranchise network. } \\
\text { Use of peer pressure to achieve } \\
\text { adherence to high quality standard }\end{array}$ \\
\hline $\begin{array}{l}\text { Microfranchisor / } \\
\text { Hub firm }\end{array}$ & $\begin{array}{l}\text { Strong mandate } \\
\text { focused on } \\
\text { creating value for } \\
\text { BOP population }\end{array}$ & $\begin{array}{l}\text { Lack of business } \\
\text { culture to sustain a } \\
\text { microfranchise } \\
\text { innovation network } \\
\text { outside of } \\
\text { philanthropic funding }\end{array}$ & $\begin{array}{l}\text { The mandate on BOP population is } \\
\text { an asset to maintain to avoid } \\
\text { mission drift of the microfranchise } \\
\text { innovation network } \\
\text { Recruit staff with business } \\
\text { experience and make room with } \\
\text { specific processes within large } \\
\text { NGO's operation to incubate and } \\
\text { successfully spin-off social } \\
\text { enterprise }\end{array}$ \\
\hline Suppliers & $\begin{array}{l}\text { Well-developed } \\
\text { supply chain in } \\
\text { BOP market }\end{array}$ & $\begin{array}{l}\text { Lack of } \\
\text { understanding of BOP } \\
\text { context and value co- } \\
\text { creation }\end{array}$ & $\begin{array}{l}\text { Select suppliers who understand } \\
\text { and committed to the goal of the } \\
\text { microfranchise network and willing } \\
\text { to adapt their business practices to } \\
\text { co-create value }\end{array}$ \\
\hline BOP farmers & $\begin{array}{l}\text { Eager to improve } \\
\text { farming as } \\
\text { business, women } \\
\text { are particularly } \\
\text { very receptive to } \\
\text { change }\end{array}$ & $\begin{array}{l}\text { Lack of trust toward } \\
\text { agro-input industry }\end{array}$ & $\begin{array}{l}\text { Include BOP farmers, especially } \\
\text { women, as part of the value co- } \\
\text { creation to harness their best ideas } \\
\text { to innovate and create value }\end{array}$ \\
\hline
\end{tabular}


The combination of innovation network theory and network imprinting theory offers a comprehensive lens for empirical inquiry into design and orchestration practices and related outcomes in innovation networks.

While the orchestration of the innovation network framework (Dhanaraj \& Parkhe, 2006) and the imprinting theory (Marquis and Tilcsik, 2013) were relevant to analyze our case study and shed insights, scholars have looked at both separately. We argue that it is by looking at the two together that we gain richer insights into the process of designing and orchestrating innovation networks to co-create value.

Through our evidence, we uncovered how each member joined the network with its imprints and how the imprints affected the network membership, thereby altering how the network was designed and orchestrated. Thus, to make the innovation network effective in achieving its outcome, it is important to be deliberate about understanding imprinting upfront and to design strategies and tactics to manage it. Furthermore, designing and orchestrating an innovation network in a BOP context has different end goals. Although achieving financial sustainability is important, maximizing profit is not often a key driver. Achieving positive social impact is equally important. Our empirical evidence revealed that the goal pursued by CARE through the Krishi Utsho microfranchise network was to allow BOP farmers' timely access to affordable, quality agricultural input and services to increase their production, income and well-being.

Hence, we propose a combined framework of designing and orchestrating innovation networks, keeping in mind the BOP context. We position the imprinting as antecedent of the network design and orchestration activities, but also as a constant factor that alters the innovation network design and orchestration. Figure 7 presents our proposed extended framework, based on theory and our empirical evidence. We consider carefully 
the circumstances in the BOP market and made some changes to the framework. In addition to having the imprinting as an antecedent that needs to be carefully identified and managed for each member of the network, including the hub firm itself and the end customers (in our case, BOP farmers), we made three modifications. The first modification is managing network sustainability as part of the network orchestration activities. We argue for sustainability instead of stability, given the fact that many networks in the BOP context tend to be short term, informal and donor dependent. While network stability is important, especially in a politically unstable environment, the nature of innovation network is constant change and disruption which ideally allows for constant innovation. Instability of the network is not bad in itself as long as the hub continues to competently manage the entire network and co-create value. However, not achieving a long term sustainability and remaining dependent on donor funding as it is the case for Krishi Utsho can jeopardize the long term viability of the network. We further elaborated on this argument below. Second, we added network imprinting management as part of the orchestration function, as discussed above. Continuous management of imprinting once the network members are selected is an important management activity to minimize negative imprinting and to leverage positive ones to achieve the outcome of the network. Third, we changed the initial network innovation output by two important network outcomes in the context of the BOP market. We advocate for financial sustainability because of the dependency of many BOP ventures on donor funding (Karamchandani, Kubzansky, \& Lalwani, 2011; London \& Hart, 2004) and the need to achieve financial independence in order to allow for scale and replication. Furthermore, we advocate for social impact as part of the network outcome. Innovation output in itself is not enough, and the network should create value for society. 
This is in line with the intent of the BOP venture to create at least a double bottom-line, achieving profit and positive change in people's life. Increasingly, many management scholars are also advocating for shared value creation between business and society (Porter \& Kramer, 2011), which is a well-founded argument in our view.

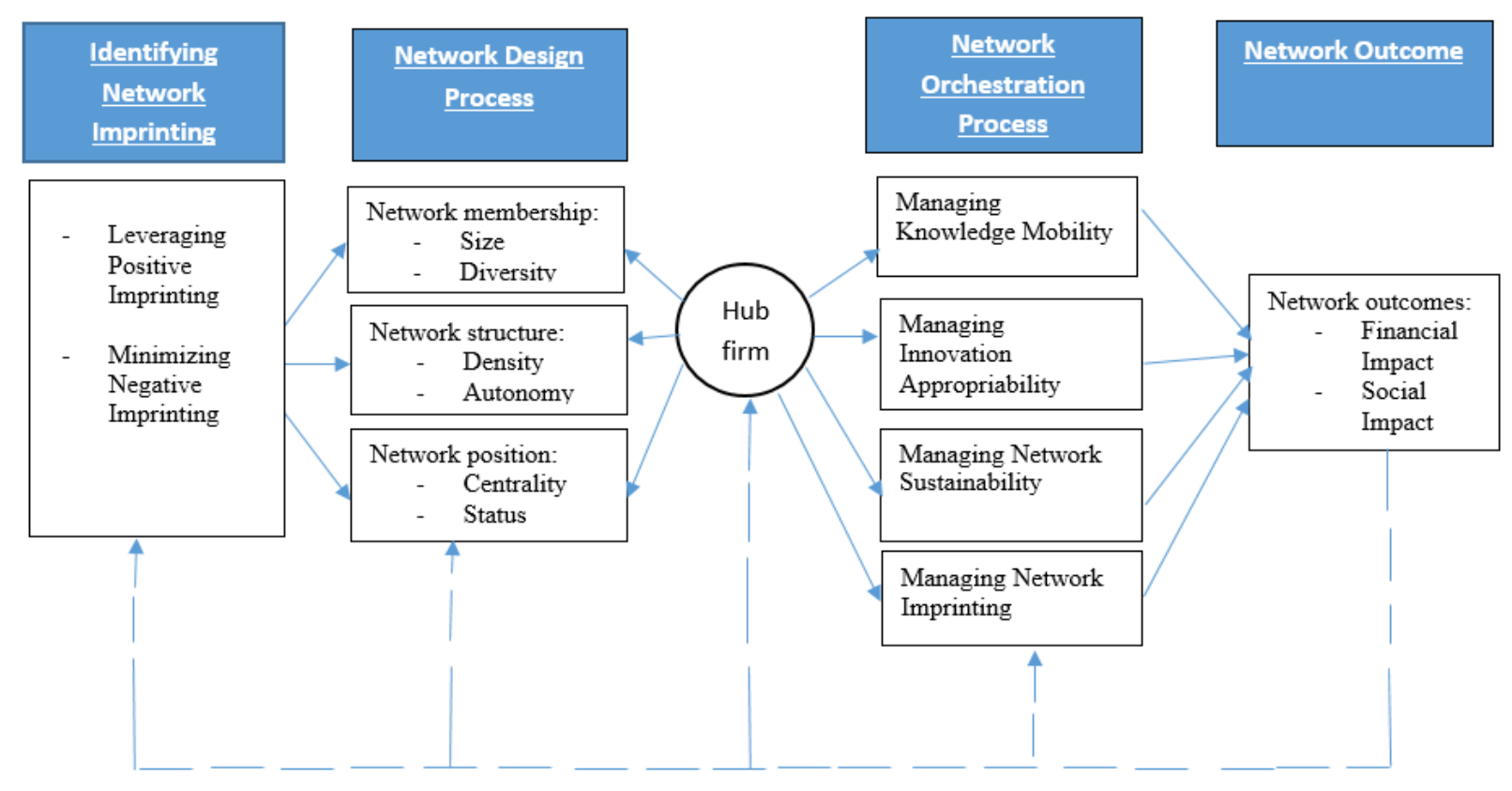

Figure 13: Adapted framework for network design and orchestration

\section{VII.2 Contributions to practice}

The empirical results demonstrated the relevance of the theoretical framework for the design and orchestration of the microfranchise network in Bangladesh. Our study also revealed a number of insights and opportunities for CARE and Krishi Utsho in the emerging microfranchise social enterprise. Against that backdrop, we present three lessons we hope CARE and other practitioners in similar situations can learn from our research. 
Lesson 1: CARE and Krishi Utsho will more likely achieve their intended goals if they continuously assess and appropriately manage the imprinting of network participants.

Network imprinting theory (Marquis and Tilcsik, 2013) plays out prominently in the way a microfranchise innovation network is designed and orchestrated. Our analysis found that Krishi Utsho had mixed results in assessing and appropriately managing the imprinting of all the network participants. We highlight three important imprints that Krishi Utsho and CARE should understand and continue to manage appropriately, in order to expand the network and co-create value between the participants, including BOP farmers.

First, Krishi Utsho needs to continue to assess and manage the imprinting of the candidate microfranchisees that are recruited to join the network. An important negative imprinting that surfaced from our findings is quality of animal health products. In fact, the animal health industry in Bangladesh, especially animal medicine and vaccinations, is not strongly regulated and enforced. As a result of this institutional void and the lack of customer formal education, which is associated with the BOP population (London et al, 2014), many firms abuse the situation and sell counterfeited products in the market. Therefore, many microfranchisees had the perverse incentive to sell counterfeited products that procure them higher revenue. Thus, they found it very difficult to change behavior as they joined the microfranchise innovative network. Krishi Utsho used a number of strategies and tactics, as revealed in our finding such as education, imposing a quality standard rule, and peer pressure, among others, to reduce this negative imprinting and to build the reputation of the network and its brand. The learning gained by Krishi Utsho should continue to help refine the selection criteria and the induction of new 
microfranchisees into the network. Krishi Utsho should also be able to gain in efficiency as it continues to develop and streamline its network design and orchestration processes.

Second, our findings revealed that many animal health firms who supplied the Krishi Utsho network already had a robust distribution chain in place in rural Bangladesh. This represents an important imprinting on the new business model. Our discussion with the representatives of those supplier firms revealed that they were not ready to modify their business model, given their strong market position and their lack of understanding of Krishi Utsho's end goal. In fact, this imprinting explained why the supplier firms did not recognize their participation in the Krishi Utsho microfranchise innovation network as strategic. The implication for Krishi Utsho is to revisit its relationship with those suppliers. Perhaps when Krishi Utsho is able to demonstrate an economy of scale, an important market share and efficiency, it may be in a position to renegotiate its current relationship with the animal health product supplier firms. Another opportunity for Krishi Utsho is to start afresh with other suppliers who are not currently selling to BOP farmers. But again, assessing and understanding the imprinting of those new suppliers and how it could be managed would still be an important consideration for Krishi Utsho. Indeed, the microfranchise innovation network has ample opportunity to introduce other lines of products that are not currently sold through the network, but are in demand by BOP farmers. The relationship with two animal feed companies and the positive results achieved to date with the branded feed with Krishi Utsho's logo, and the new coconut oil cake, provide evidence of an ability to fulfil previously unmet demand, and a track record on which Krishi Utsho can build. Poultry, fisheries, agricultural equipment, financing, and IT are many other opportunities Krishi Utsho could develop with other suppliers to forge 
mutually beneficial partnerships. Krishi Utsho needs to consider carefully if any of the new supplier firms are willing to alter their imprinting to do business with the network and cocreate value.

Finally, our findings revealed that CARE itself was heavily imprinted as an incubating entity of the Krishi Utsho microfranchise innovation network. CARE is a seventy-year-old nonprofit global organization with large-scale humanitarian and longterm poverty reduction programs in Bangladesh and in over ninety other countries. CARE's brand recognition and reputation served Krishi Utsho well, as revealed by our empirical evidence. An example is the trust the CARE brand commanded with BOP farmers, given CARE's history of over sixty years in Bangladesh. The same is true of the franchisees themselves, as CARE provided entrepreneurial assistance to many of them through the Dairy Value Chain Project funded by the Bill and Melinda Gates Foundation. Another important advantage Krishi Utsho derived from its association with CARE was the philanthropic funding it was able to mobilize to initiate and develop the microfranchise innovation network. Without this funding, the network would have struggled to grow, given its novelty and social mission. On the other hand, Krishi Utsho faced important imprinting challenges as a startup incubated within a large humanitarian and development organization with no prior experience in developing a microfranchise innovation network. This had implications for the design, orchestration and performance of the network as revealed in our findings. One example is the fact that Krishi Utsho was forced to outsource the supply chain management of the network to a third party firm due CARE's onerous warehouse policy that was not adapted for the startup operations of Krishi Utsho. This added complexity and cost to the innovation network. Another piece of empirical evidence 
is that CARE's traditional and nonprofit human resource policy inhibited Krishi Utsho from using a market-based commercial approach to hire competent staff who are remunerated based on performance targets. This slowed down the operations, and it took over a year to hire a managing director of the network with experience in supply chain and business management. A lesson learnt from this process is the need for a better awareness within nonprofit leadership, aiming to incubate social enterprises. They may consider developing parallel processes for a social enterprise startups. This may help resolve some of the operational challenges faced by Krishi Utsho.

Lesson 2: CARE and Krishi Utsho will more likely have sustained impact if they systematically experiment with and gradually transition to financially self-sustained strategies and practices with social impact on BOP farmers.

Ensuring network stability, especially in a very fragile political environment is extremely important, and our findings revealed that Krishi Utsho demonstrated relevant attributes in this regard. However, in an innovation network, change is constant and disruption helps to push the envelope for innovation creation. Ensuring financial sustainability and positive social impact is therefore more important for BOP ventures than only ensuring stability. As found by many researchers and as argued earlier, organizations engaged in BOP ventures have struggled to achieve financial sustainability in order to create new business models suitable for the BOP environment (Karamchandani, Kubzansky, \& Lalwani, 2011; London \& Hart, 2004). Krishi Utsho did, however, prove that the microfranchise business model is attractive to BOP micro-entrepreneurs who converted to become microfranchisees. Within a year, many were able to break even and become profitable. On average, they increased their sales revenue by $50 \%$ more than similar micro-entrepreneurs who had not yet fully converted to the network. This 
achievement encouraged many other micro-entrepreneurs to join the network. Achieving financial sustainability is equally crucial for Krishi Utsho as a hub firm and microfranchisor for many reasons.

First, while philanthropic funding is helpful, given the dire poverty context in which Krishi Utsho is operating, the continuity of this type of funding is not guaranteed. In fact, many scholars and pundits argue against relying only on philanthropist funding, given the unstable, short-term project focus of such sources. They argue for more long-term patient capital instead (Easterly, 2006; Woodworth, 2007). Additionally, they argue that microfranchisee and consumer awareness of donor involvement can hinder the economic success of BOP endeavors (Kistruck \& Beamish, 2010). Second, we posit that a social business such as Krishi Utsho should be able to achieve a certain level of financial independency in order to be able to continue to expand the network, innovate, and create value. As of the end of December 2015, the network is only able to cover $25 \%$ of its operation costs through the revenue it generates. The remaining amount is covered by philanthropic funding. Third, we argue that achieving financial independence will give confidence to CARE and any other organizations interested in BOP population and microfranchising to replicate and scale-up the Krishi Utsho business model, elsewhere and in other industries.

Achieving financial sustainability without the social impact intended on the BOP population is meaningless, given the mandate of Krishi Utsho as a social enterprise. Fortunately, the survey conducted by Krishi Utsho, on the BOP farmer's customers in 2015, demonstrated many indications of a positive impact. Streamlining the impact measurement process as part of the routine business operations and leveraging 
technological platforms, such as mobile phones, could be an opportunity for Krishi Utsho to explore. Developing a robust and cost effective customer management relationship system is another opportunity Krishi Utsho needs to consider after collecting timely feedback from its customers, in order to continuously improve its operations and impact on BOP farmers.

Lesson 3: CARE and other development organizations will more likely leverage microfranchise models if they design and orchestrate their efforts as emergent innovation networks.

Our study focuses on how a microfranchise network may be designed and orchestrated to co-create value, given the gap in BOP and microfranchising literature. Because networks are often studied from structural, relationship and outcome perspectives (Cook \& Whitmeyer, 1992), using the innovation network theory (Dhanaraj and Parkhe, 2006) offers relevant insights for practice, not only for CARE, but for many other organizations interested in developing a microfranchise network to co-create value within a BOP population. As posited by Dhanaraj and Parkhe, for an innovation network to be designed and orchestrated, there is a need for a central actor called the hub firm. In this case, CARE, through Krishi Utsho fulfilled the hub firm role as network designer and orchestrator. Krishi Utsho demonstrated several of the attributes that Dhanaraj and Parkhe identified with a hub firm, such as the prominence and power position within the network, and being a leader and connector, influencer and value creator. In particular, Krishi Utsho placed a strong focus on its value creator role, not only for the network members, but also for the BOP farmers who are the "raison d'être" of the creation of the microfranchise network. 
From a design perspective, Krishi Utsho artfully identified and recruited the first cohort of microfranchisees and evolved the process over time, based on lessons learnt. As our evidence pointed out, Krishi Utsho maintained a low attrition rate among the microfranchisees. Only four microfranchisees dropped out, with the total number of microfranchisees increasing from the initial 15 to 110 . Krishi Utsho also demonstrated an increasing understanding of how to grow its supplier firms as members of the network. Our findings demonstrated that Krishi Utsho engaged in a delicate balancing act to structure the network membership and to position itself as a central player despite the challenges that it faced with the animal health supplier firms. From a network orchestration standpoint, our empirical evidence suggests Krishi Utsho demonstrated orchestration of innovation network characteristics, such as managing knowledge mobility and innovation appropriability throughout the network. We provided some concrete examples of this in our previous sections. Krishi Utsho also managed to stabilize the network, especially in times of crisis, such as during the political turmoil which paralyzed the economic activities of the entire country in 2013 and 2015.

While the findings support the case that Krishi Utsho has demonstrated effective orchestration of the network, there was no deliberate framework or playbook by which the orchestration took place. Most of the orchestration was trial and error, given the lack of prior experience within CARE and within the industry. Thus, the rigorous process suggested by Dhanaraj and Parkhe in the orchestration of innovation networks, with some adaptation to the BOP context, could help streamline the orchestration process. For instance, there was no deliberate innovation development process in place to stimulate the members of the network, the BOP farmers, or anyone else, to suggest, innovate, or to be 
rewarded to grow the network to co-create value. The lack of such processes creates the potential for unauthorized imitation which can stifle and weaken innovation appropriability (Sakakibara, 2002; Teece, 2000), especially in the context of institutional voids that characterize BOP markets with weak legal institutions (Kistruck et al., 2013). CARE and other organizations that are interested in designing and implementing a microfranchise network could, therefore, make use of the orchestration of innovation network framework.

\section{VII.3 Limitations}

Although this dissertation contributes new knowledge and insights to advance the knowledge and practice of microfranchising to engage the BOP, the study has few limitations. First, we used a single qualitative case study that may limit our ability to draw rich insights to inform our contributions to theory and practice. Ideally, we would have liked to research other similar microfranchise innovation networks from various industries (consumer goods, health, financial services, etc.), orchestrated by other actors, such as private corporations and non-governmental organizations such as CARE. Further studies could also look at the end goal of such networks, whether it is profit, positive social impact, or a combination of the two. Therefore, this represents an opportunity for further study to test some of the propositions as well as the new integrated framework combining the imprinting and network innovation we developed. Second, our study was qualitative in nature, which presents some limitations to generalize to a larger population of microfranchise innovation networks. Our propositions are, however, generalizable to theory. Our lessons also offer important insights to improve the design and orchestration of innovation networks. Nevertheless, it might be useful to conduct quantitative or mixed 
method research to further test our propositions and the new integrated framework to draw additional conclusions.

Third, a good part of our data was recalled by the participants. This may be subjected to forgetting as people's memory fails. We, however, triangulated the data obtained and made use of the extensive literature available on our case to remain as much as objective as we can.

Fourth, another limitation of this study may be some personal biases, given my position as a CARE employee and my involvement in advising the team in Bangladesh during the design and orchestration of the Krishi Utsho innovation network. However I remained as objective and impartial as possible. I used several methods, such as triangulating the information I gathered, engaging the practitioners themselves to review my result section and collecting several feedbacks from many others researchers, including my committee members. Although a limitation, this was an opportunity for us to draw from our personal experience to access data and insights that might otherwise be difficult for an outside researcher. In addition, the engaged scholarship promoted by Van de Ven (2007), among other scholars, advocates for this type of practitioner/researcher as part of the new wave of applied research that uses scientific knowledge to influence practice, and vice versa.

\section{VII.4 Conclusion}

Our study examines how innovation networks are designed and orchestrated in an embedded context. We studied an emerging microfranchise innovation network that CARE 
is facilitating in Bangladesh to provide timely access to quality agricultural input and services to thousands of BOP farmers.

Our results revealed four main stages in the design and orchestration processes that were matched-up with the orchestration of the innovation network, as well as network imprinting theories. We found very interesting insights to contribute to the gap in the literature and to the practice on how such innovation networks are designed and orchestrated in a BOP context. Imprinting manifested prominently in our findings, and we highlighted the need to identify it up front and to manage it during the design and orchestration of the innovation network.

We also highlighted two categories of imprinting, both negative and positive, and the important role the hub firm plays in managing it, leveraging the positive imprints to achieve the goal of the network, while minimizing the damaging impact of the negative imprints.

We also found that microfranchise networks are indeed innovation networks and could benefit from using the framework developed by Dhanaraj and Parkhe (2006) to better manage knowledge mobility and innovation appropriability. Furthermore, we demonstrated how network imprinting theory and the orchestration of innovation network theory could be combined as an integrated framework to inform the design and orchestration processes.

We argued that imprinting should be an antecedent function of the innovation network, as well as continuous management activities as part of the orchestration process. We also suggested a few additional variables to be added to the framework, such as 
managing for sustainability, in addition to stability and creating a double bottom line financial and social impact, as part of the innovation outcome. We argued for these additions, given the entrenched societal issues that such innovation networks try to achieve.

Finally, we contributed several lessons for practitioners at CARE and other organizations interested in designing and orchestrating innovation networks in an embedded context. We argued that our findings could well be applicable to the context of other developed countries.

As such, considering the gap in the literature and the infancy of microfranchising as a tool to fight poverty and contribute to economic development, our study advances knowledge and practice, and is a source of inspiration for further research. 


\section{APPENDIXES}

\section{Appendix A: Name of supplier firms in Krishi Utsho network}

\begin{tabular}{|c|c|c|}
\hline Input & Input Supplier & $\begin{array}{l}\text { Establishment } \\
\text { of Partnership }\end{array}$ \\
\hline \multirow{4}{*}{ Feed } & Tamin Agro Industries Ltd. & \multirow{7}{*}{$2012-13$} \\
\hline & Fatema Feed & \\
\hline & ACI Godrej Agrovet & \\
\hline & Private Ltd. & \\
\hline \multirow{6}{*}{ Medicine } & Chemist Agrovet Ltd & \\
\hline & $\begin{array}{l}\text { The ACME Laboratories } \\
\text { Ltd. }\end{array}$ & \\
\hline & Opsonin Pharma Ltd. & \\
\hline & $\begin{array}{l}\text { Square Pharmaceuticals } \\
\text { Ltd. }\end{array}$ & \multirow{3}{*}{$2013-14$} \\
\hline & Renata Ltd. & \\
\hline & Novartis (BD) Ltd. & \\
\hline
\end{tabular}

\section{Appendix B: Detailed results of test on Coconut Oil Cake}

\begin{tabular}{|c|c|c|c|c|c|c|c|c|c|c|c|}
\hline \multirow[b]{2}{*}{ Day } & \multirow{2}{*}{$\begin{array}{c}\text { Body } \\
\text { Weight }\end{array}$} & \multirow{2}{*}{$\begin{array}{c}\text { Age } \\
\text { of } \\
\text { Calve } \\
s \\
\text { (day) }\end{array}$} & \multirow{2}{*}{$\begin{array}{l}\text { Green } \\
\text { Grass }\end{array}$} & \multicolumn{4}{|c|}{$\begin{array}{c}\text { Consumption (Qty) } \\
\text { Concentrate Provided }\end{array}$} & \multicolumn{2}{|c|}{$\begin{array}{c}\text { Milk Production } \\
\text { (Qty) }\end{array}$} & \multicolumn{2}{|c|}{$\begin{array}{l}\text { Effect on Fat } \\
(\%)\end{array}$} \\
\hline & & & & $\begin{array}{l}\text { Rice } \\
\text { bran }\end{array}$ & $\begin{array}{l}\text { Wheat } \\
\text { Bran }\end{array}$ & Others & $\begin{array}{l}\text { Coconut } \\
\text { Oil Cake }\end{array}$ & $\begin{array}{l}\text { First } \\
\text { Half }\end{array}$ & $\begin{array}{l}\text { Second } \\
\text { Half }\end{array}$ & $\begin{array}{l}\text { First } \\
\text { Half }\end{array}$ & $\begin{array}{c}\text { Seco } \\
\text { nd } \\
\text { Half }\end{array}$ \\
\hline $\begin{array}{c}\text { Day- } \\
1\end{array}$ & $235 \mathrm{~kg}$ & 40 & $35 \mathrm{~kg}$ & 0 & $2.5 \mathrm{~kg}$ & Water & $1.0 \mathrm{~kg}$ & $4.5 \mathrm{Lt}$ & $4.0 \mathrm{Lt}$ & 3.2 & 3.2 \\
\hline $\begin{array}{l}\text { Day- } \\
2\end{array}$ & $235 \mathrm{~kg}$ & 41 & $30 \mathrm{~kg}$ & 0 & $3.5 \mathrm{~kg}$ & Water & $1.5 \mathrm{~kg}$ & $4.5 \mathrm{Lt}$ & $4.0 \mathrm{Lt}$ & 3.4 & 3.3 \\
\hline $\begin{array}{l}\text { Day- } \\
3\end{array}$ & $235 \mathrm{~kg}$ & 42 & $32 \mathrm{~kg}$ & 0 & $3.5 \mathrm{~kg}$ & Water & $1.5 \mathrm{~kg}$ & $5.0 \mathrm{Lt}$ & $4.5 \mathrm{Lt}$ & 3.4 & 4 \\
\hline $\begin{array}{l}\text { Day- } \\
4\end{array}$ & $235 \mathrm{~kg}$ & 43 & $30 \mathrm{~kg}$ & 0 & $3.0 \mathrm{~kg}$ & Water & $2.0 \mathrm{~kg}$ & $5.0 \mathrm{Lt}$ & $4.5 \mathrm{Lt}$ & 3.6 & 4.8 \\
\hline $\begin{array}{l}\text { Day- } \\
5\end{array}$ & $235 \mathrm{~kg}$ & 44 & $35 \mathrm{~kg}$ & 0 & $3.0 \mathrm{~kg}$ & Water & $2.0 \mathrm{~kg}$ & $5.0 \mathrm{Lt}$ & $4.5 \mathrm{Lt}$ & 3.5 & 4.1 \\
\hline $\begin{array}{l}\text { Day- } \\
6\end{array}$ & $235 \mathrm{~kg}$ & 45 & $30 \mathrm{~kg}$ & 0 & $3.0 \mathrm{~kg}$ & Water & $2.0 \mathrm{~kg}$ & $5.5 \mathrm{Lt}$ & $5.0 \mathrm{Lt}$ & 3.8 & 4.9 \\
\hline $\begin{array}{l}\text { Day- } \\
7\end{array}$ & $235 \mathrm{~kg}$ & 46 & $30 \mathrm{~kg}$ & 0 & $3.0 \mathrm{~kg}$ & Water & $2.2 \mathrm{~kg}$ & $5.5 \mathrm{Lt}$ & $5.0 \mathrm{Lt}$ & 3.7 & 5.1 \\
\hline $\begin{array}{l}\text { Day- } \\
8\end{array}$ & $235 \mathrm{~kg}$ & 47 & $35 \mathrm{~kg}$ & 0 & $3.0 \mathrm{~kg}$ & Water & $2.2 \mathrm{~kg}$ & $5.5 \mathrm{Lt}$ & $5.0 \mathrm{Lt}$ & 3.6 & 4.1 \\
\hline
\end{tabular}


Appendix C: Customer impact results

Savings of Cost and Time:

\begin{tabular}{|c|c|c|c|c|c|c|}
\hline & \multicolumn{2}{c}{ Feed } & \multicolumn{2}{c}{ Medicine } & \multicolumn{2}{c|}{ Vitamin } \\
& Before & \multicolumn{1}{c}{ After } & \multicolumn{1}{c}{ Before } & \multicolumn{1}{c|}{ After } & \multicolumn{1}{c|}{ Before } & After \\
\hline & 2.2 & 0.9 & 2.5 & 7.6 & 2.6 & 1.7 \\
Distance Travelled (KM) & 8 & 8 & 9 & 7 & 5 & 9 \\
\hline $\begin{array}{c}\text { Time Spent for Travel } \\
\text { (Min.) }\end{array}$ & 28.2 & 12.1 & 28.0 & 15.5 & 27.3 & 16.8 \\
\hline Cost of Travel (BDT) & 6 & 2 & 7 & 5 & 9 & 9 \\
\hline
\end{tabular}

\section{Frequency of visit:}

\section{Indicator Before After Cause}

$\begin{array}{llll}\text { Frequency of Visit } & 2.84 & 3.7 & \text { Frequency has increased due to the proximity of shops to the }\end{array}$ community

\section{Social Impact}

\section{Women Empowerment:}

\begin{tabular}{|lcc|}
\hline & Before & After \\
\hline Influence of Women in HH Decision making & $46 \%$ & $85 \%$ \\
\hline Influence of Women in house renovation decision & $25 \%$ & $95 \%$ \\
\hline Influence of Women in Husband's Income generation & $24 \%$ & $84 \%$ \\
\hline
\end{tabular}

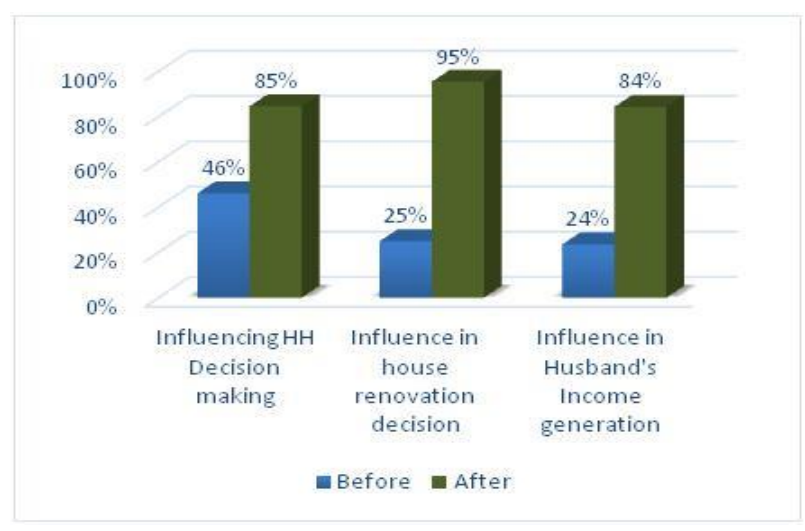




\section{Food Security}

\begin{tabular}{|lcc|}
\hline Major Food Type & Expenditure \\
\hline & Before & After \\
\hline Rice/Wheat & 579 & 626 \\
\hline Fish/Meat & 543 & 622 \\
\hline Vegetables & 346 & 393 \\
\hline
\end{tabular}

\section{Perception toward Krishi Utsho}

The survey has also collected data on farmers' perception of Krishi Utsho's impact on their lives. Figure below presents the perception on eight potential indicators. It turns out that $58 \%$ farmer experienced increased expenditurevc in goods, $56 \%$ experienced increases in educational spending, $57 \%$ increase health spending, $54 \%$ of farmers experience increases in agriculture expenditure. Same as seen food, cow health, dairy consumption a dairy yield.

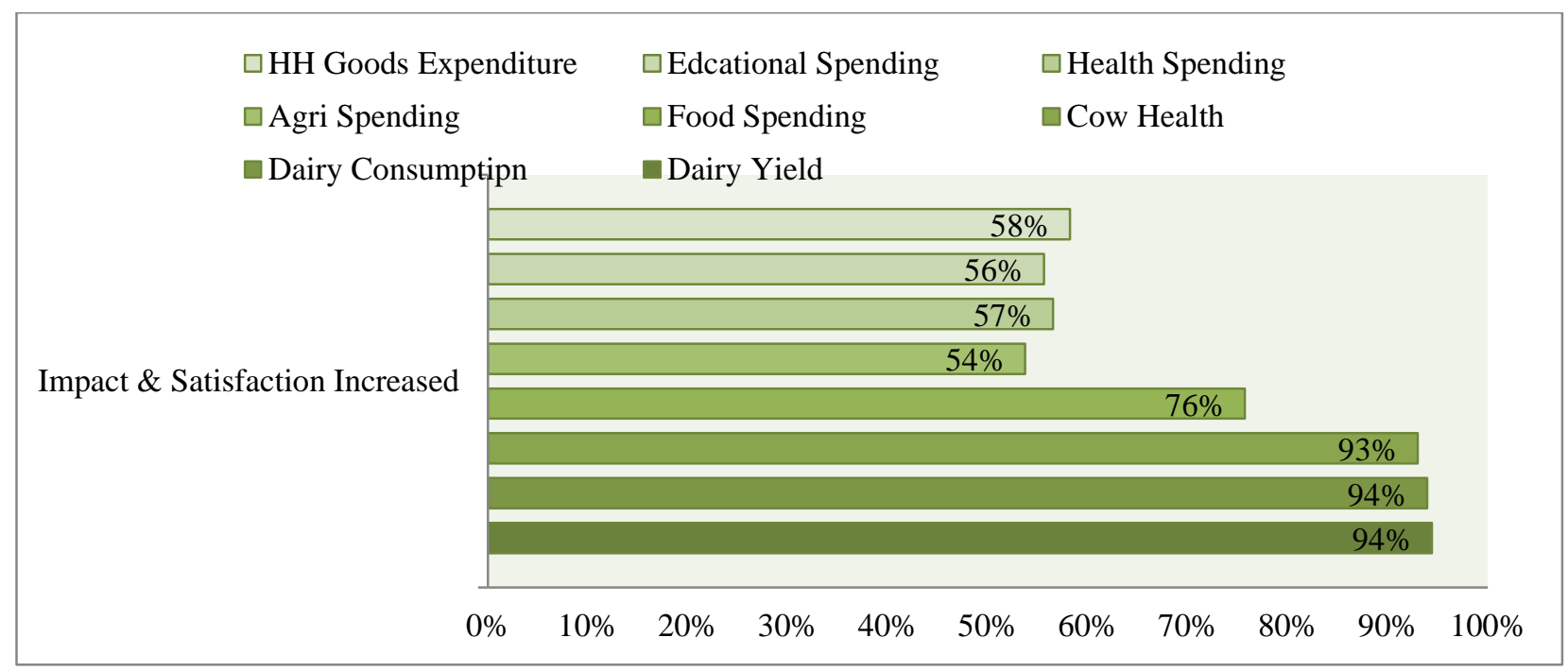




\section{REFERENCES:}

Ahuja, G., Soda, G., \& Zaheer, A. (2012). The genesis and dynamics of organizational networks. Organization Science, 23(2), 434-448.

Albert, S. \& Whetten, D.A. (1985). Organizational identity. Research in Organizational Behavior 7: 263-295

Bamford, C. E., Dean, T. J., \& McDougall, P. P. (2000). An examination of the impact of initial founding conditions and decisions upon the performance of new bank startups. Journal of business venturing, 15(3): 253277.

Brass, D. J., \& Burkhardt, M. E. (1993). Potential power and power use: An investigation of structure and behavior. Academy of Management Journal, 36: 441-470.

Christensen, L.J., Parsons, H., \& Fairbourne, J. (2010). Building entrepreneurship in subsistence markets: Microfranchising as an employment incubator. Journal of Business Research, $63,595-601$.

Combs, J.G. \& Ketchen, D.J., Jr. (1999b). Explaining interfirm cooperation and performance: Toward a reconciliation of predictions from the resource-based view and organizational economics. Strategic Management. Journal, 20, 867-888.

de Soto H. 2000. The Mystery of Capital: Why Capitalism Triumphs in the West and Fails Everywhere Else. Basic Books: New York.

Dhanaraj, \& Parkhe. (2006). Orchestrating Innovation Networks. Academy of Management Review, Vol. 31, No 3, 659-669(3), 659-669. 
Easterly, W. (2006). The white man's burden: Why the West's efforts to aid the rest have done so much ill and so little good. New York: Penguin Press.

Fairbourne, J. (2007). Why microfranchising is needed now: Introduction and book overview. In J. Fairbourne.

Gibson, S. W. \& Dyer, W.G. (Eds.), (2007). Microfranchising: Creating wealth at the bottom of the pyramid (pp. 17-42). Northampton, MA: Edward Elgar.

FAO, IFAD and WFP. 2014. The State of Food Insecurity in the World 2014. Strengthening the enabling environment for food security and nutrition. Rome, FAO.

Fowler, A. (2000). NGO futures beyond aid: NGDO values and the fourth position. Third World Quarterly,21, 589-603.

Hemme, T. (2010). IFCN Dairy Report 2010. International Farm Comparison Network, IFCN Dairy Research Center, Kiel,Germany, website: www.ifcndairy.org

Javier Busquets, Orchestrating Smart Business Network dynamics for innovation, Management of Information Systems, ESADE, Spain.

Karamchandani, A., Kubzansky, M., \& Lalwani, N. 2011. Is the bottom of the pyramid really for you? Harvard Business Review, 89(3): 107-111.

Kistruck, G. M., Webb, J. W., Sutter, C. J., \& Ireland, R. D. (2011). Microfranchising in Base-ofthe-Pyramid Markets: Institutional Challenges and Adaptations to the Franchise Model (Vol. May 2011).

Kistruck, G. \& Beamish, P. (2010). The interplay of form, structure, and embeddedness in social intrapraneurship. Entrepreneurship Theory and Practice, 34, 735-761. 
Kistruck, G. M.,Webb, J. W., Sutterc, C. J., \& Baileyd, A. V. G. (2015). The double-edged sword of legitimacy in base-of-the-pyramid markets. Journal of Business Venturing, Volume 30, Issue 3 .

Kriauciunas, A., \& Kale, P. (2006). The Impact of Socialist Imprinting and Search on Resource Change: A Study of Firms in Lithuania. Strategic Management Journal, 27: 659679.

Kriauciunas, A., \& Shinkle, G. (2008). Organizational Imprinting: Informing Firm Behavior in Domestic and International Contexts. Purdue e-Pubs

Levén, P., Holmström, J., \& Mathiassen, L. (2014). Managing research and innovation networks: Evidence from a government sponsored cross-industry program. Research Policy, Research Policy 43(0048-7333), 156-168.

Lehr, D. (2008). Microfranchising at the base of the pyramid. Acumen Fund. Available at http://www.acumenfund.org/uploads/assets/documents/Microfranchising_Working\%20P aper_XoYB6sZ5.pdf, accessed October 22, 2009.

Lounsbury, M. (2002). Institutional transformation and status mobility: The professionalization of the field of finance. Academy of Management Journal, 45, 255-266.

Marquis, C., Tilcsik, A. (2013). Imprinting: Toward a Multilevel Theory. The Academy of Management Annals, Vol.7, No. 1, 195-245.

Mathiassen, Lars. (2002). Collaborative practice research. Information Technology \& People, 15(4), 321-345.

Miles, M.B, Huberman, A,M and Saldana, J. 2013. Qualitative Data Analysis, A Methods Sourcebook. Sage: Thousand Oaks, CA. 
Magleby, K. (2007). Microfranchise business models. In J. Fairbourne, S.W. Gibson, \& W.G. Dyer (Eds.), Microfranchising: Creating wealth at the bottom of the pyramid (pp. 133148). Northampton, MA: Edward Elgar.

Parkhe, A. 1993. Strategic alliance structuring: A game theoretic and transaction cost examination of interfirm cooperation. Academy of Management Journal, 36: 794- 829.

Porter, M. E. and Kramer, M. R. (2011). Creating Shared Value. How to Reinvent Capitalism and Unleash a Wave of Innovation and Growth. Havard Business Review, HBR.ORG

Prahalad, C.K. \& Hammond, A. (2002). Serving the world's poor, profitably. Harvard Business Review, 80, 4-11.

Pratt, M.G. \& Foreman, P.O. (2000): Classifying managerial responses to multiple organizational identities. In: Academy of Management Review 25 (1): 18-42.

Ragan, V., Leonard, H., McDonald, S. (2008). The Future of Social Enterprise. Harvard Business School Working Paper, 08-103.

Rometsch, M. \& Sydow, J. (2003): Identities of Networks and Organizations - The Case of Franchising. EMNet-Conference on "Economics and Management of Franchising Networks" Vienna, Austria, June 26-28, 2003 www.univie.ac.at/EMNET

Simanis, E., Hart S. (2008). The Base of the Pyramid Protocol: Toward Next Generation BoP Strategy, Center for Sustainable Global Enterprise

Singh, R. (2011). Towards Information Polycentricity Theory - Investigation of a Hospital Revenue Cycle. PhD Dissertation, Georgia State University

Soda, G., Usai, A., \& Zaheer, A. (2004). Network memory: The influence of past and current networks on performance. The Academy of Management Journal, 47(6), 
893-906.

Stinchcombe, A.L. (1965). Social structure and organizations. In J.G. March (Ed.),

Handbook of organizations (pp. 142-193). Chicago, IL: Rand McNally.

Sutter, J. C., Kistruck, G. M., \& Morris, S. (2014). Adaptation to Knowledge Templates in BaseOf-the Pyramid Market: The Role of Social Interaction. Strategic Entrepreneurship Journal., 8: 03-320.

Uddin, M.M., Sultana, M.N., Ndambi, O.A., Alqaisi, O., Hemme, T., \& Peters, K.J. Milk (2011). Production trends and dairy development in Bangladesh. Outlook on AGRICULTURE, Vol 40,No 3, 2011.

Van de Ven, A., 1986. Central problems in the management of innovation. Management Science $32(5), 590-607$.

Van de Ven, A., 2007. Engaged scholarship: a guide for organizational and social research: a guide for organizational and social research. Oxford University Press.

Wasserman, S., \& Galaskiewicz, J. (Eds.). 1994. Advances in social network analysis. London: Sage.

Weick, K. E. 1976. Educational organizations as loosely coupled systems. Administrative Science Quarterly, 21: 1-19.

Woodworth, W. (2007). Current international development tools to combat poverty. In J. Fairbourne, S.W. Gibson, \& W.G. Dyer (Eds.), Microfranchising: Creating wealth at the bottom of the pyramid (pp. 78-99). Northampton, MA: Edward Elgar.

Yin, R.K., 2003. Case Study Research: Design and Methods. Thousand Oaks, CA,Sage. 


\section{VITA}

Laté Lawson-Lartego is a lifelong learner, a passionate to make a positive difference in people's life, an innovative, strategic and entrepreneurial leader and senior manager with over 19 years professional experience and expertise in institutional development, change management, strategic planning and execution, diverse and geographically dispersed team management, coaching and development, executive decision-making and results oriented.

Laté has proven expertise in business strategies and execution, especially as applied to poverty reduction issues, inclusive and sustainable economic development, food and nutrition security, agriculture value chain development, financial services (including microfinance), social enterprise development, private sector engagement, gender equality, women empowerment, inclusive governance and resilience building.

Laté is currently Senior Director, Food and Nutrition Security Department at CARE USA, a Global Humanitarian and Development Organization headquartered in Atlanta, USA. As such, Laté leads a global team of Agriculture and Market Systems, Food Security, Nutrition, Research, Learning and Advocacy staff to deliver CARE's goal of achieving food and nutrition security outcomes for 50 million people in Africa, Asia and Latin America and Caribbean by 2020.

Prior to taking up this new role in March 2016, Laté was Director for the Agriculture \& Market Systems Team for CARE USA between 2014 and 2016. His overall responsibility in that role was to provide global strategic and technical leadership and assistance to CARE's programs in agriculture, market access and social enterprises development. 
Before that, Laté was Director Economic Development Unit for CARE USA still based in Atlanta. In that position, which Laté held between 2008 and 2013, he led the development and execution of CARE's successful Market Engagement Strategy to create employment and dignified income for 10 million women and their family in Africa, Asia and Latin America. He led with his team and a partner a publication of a book that captures CARE's experience in Making Markets More Inclusive available at: www.palgrave.com.

Laté also held other important positions in the US as well as in Africa and Europe in nonprofit organizations as well as in for profit companies. Some select positions Laté held include Country Director for CARE Benin, Economic Development Program Coordinator for CARE Gulf of Guinea (Benin, Togo and Ghana), Analyst with PlaNet Finance in France and Auditor for Consult Services in Togo.

Laté is a member of a number of strategic committees and boards within CARE including CARE Social Enterprise, CARE Africa Microfinance Investment Fund, CARE Climate Change Network, CARE-WWF Steering Committee and CARE-Cornell University Strategic Partnerships. Laté is also board director for other non-profit and social venture organizations, including Livelihood Basics Inc. and Diaspora for Development (DIADEV). Laté is also an alumni from Leadership Atlanta.

Laté is author and co-author of articles in industry journals and books. He has served as a speaker and presenter at Economic Development, Social Enterprise, and Poverty Reduction related industry events.

Laté holds a Master of Arts in Development Studies (Rural and Social Development) with University of Reading, UK, a Master in Economics with major in 
Business Administration with Université du Benin, Togo and a Doctorate in Business from Georgia State University, USA.

Laté resides in Metro-Atlanta with his wife Regina, a daughter Rudy and two boys Regis and Ryan. 